$1-24-2017$

\title{
The Power of Community Action:Anti-Payday Loan Ordinances in Three Metropolitan Areas
}

\author{
Nathalie Martin \\ University of New Mexico - School of Law \\ Robert N. Mayer \\ University of Utah \\ Steve Graves \\ California State University
}

Follow this and additional works at: https://digitalrepository.unm.edu/law_facultyscholarship

Part of the Law Commons

\section{Recommended Citation}

Nathalie Martin, Robert N. Mayer \& Steve Graves, The Power of Community Action:Anti-Payday Loan Ordinances in Three Metropolitan Areas, (2017).

Available at: https://digitalrepository.unm.edu/law_facultyscholarship/355

This Report is brought to you for free and open access by the School of Law at UNM Digital Repository. It has been accepted for inclusion in Faculty Scholarship by an authorized administrator of UNM Digital Repository. For more information, please contact amywinter@unm.edu, Isloane@salud.unm.edu,sarahrk@unm.edu.

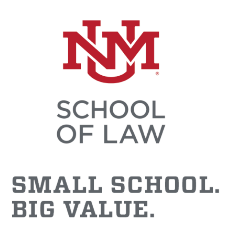

BIG VALUE. 
THE

UNIVERSITY

OF UTAH

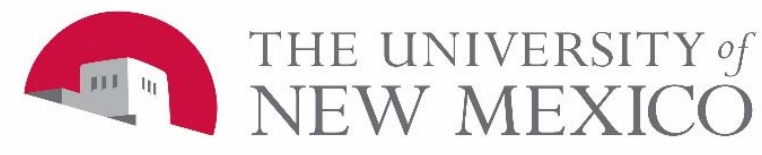

The Power of Community Action: Anti-Payday Loan Ordinances in Three Metropolitan Areas

Robert N. Mayer

Professor of Family and Consumer Studies

University of Utah

Nathalie Martin

Frederick M. Hart Chair in Consumer and Clinical law

University of New Mexico School of Law

With the assistance of:

Steve Graves, Professor of Geography, California State University,

Northridge

This report was made possible through the support of Silicon Valley Community Foundation.

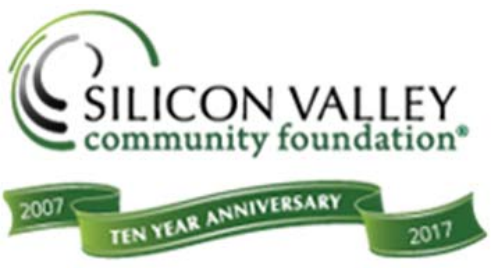

January 24, 2017 


\section{Contents}

Abstract

1: Executive Summary

2: Utah's Salt Lake County Leads by Example

3: Silicon Valley Earthquake - How Grassroots Advocacy Shook Up Payday Lending

4: The Metropolitan Dallas Experience - Passion, Perseverance, and Collaboration

5: Campaign Impacts

Exhibits

Acknowledgements

About the Authors 


\begin{abstract}
Local ordinances that restrict payday lending constitute an important strategy in the overall attack on this problematic form of lending. In this report, made possible by the generous support of Silicon Valley Community Foundation, we describe and analyze campaigns in three locales that differ markedly in the opportunities and challenges faced by ordinance advocates. The locales are Santa Clara and San Mateo counties in California ("Silicon Valley"); Dallas, Denton, and Tarrant counties in Texas; and Salt Lake County in Utah. This report finds both commonalities and important variations among these campaigns. While there is no single recipe for a successful ordinance campaign, our comparative analysis suggests the following ten lessons for payday lending opponents and other advocates of social reform via local action. The lessons, in brief, are as follows:
\end{abstract}

Lesson \#1: Form a strong broad-based coalition and develop rules for its operation.

Lesson \#2: Move beyond abstractions like " $500 \%$ interest" or "debt traps" and gather stories from actual borrowers about the effects of these loans on their lives. Seek the help of social service providers who are part of your coalition in gathering these stories and empowering borrowers to share them at public hearings.

Lesson \#3: Seek financial support for campaigns if you can, but never assume that ample financial resources are necessary for a successful campaign.

Lesson \#4: Involve faith leaders in a meaningful and ongoing way early in any campaign.

Lesson \#5: Cultivate strong working relationships with the press and create a detailed strategy for working effectively and consistently with members of the local media.

Lesson \#6: Identify and cultivate a member of the city council (or county board of supervisors) who will serve as your campaign's inside champion. In some instances, more than one potential champion may be necessary when sensitive politics or rivalries make the choice of a single champion problematic.

Lesson \#7: Identify and schedule meetings with city decision makers well in advance of any key votes. Be prepared in these meetings to present strong arguments in favor of any ordinance. These arguments will depend on local politics. Under some conditions, the negative impact on borrowers will be most persuasive; in others, the impact of payday lending on local economies, crime, blight, and the general image of a particular city will the city will be most effective. 
Lesson \#8: Carefully prepare to respond to industry arguments, especially the argument that there are no alternatives to payday loans. Develop a concrete list of payday alternatives that can be shared with members of the public as well as policy makers early in any campaign.

Lesson \#9: Once one ordinance passes, help other municipalities pass similar ordinances in other cities.

Lesson \#10: Use the power of your coalition to press for further state and federal payday loan reform in partnership with the many organizations across the country that are seeking to curb payday lending and other forms of high-cost lending. 


\section{Executive Summary}

The purpose of this report is to describe and assess campaigns to curb payday lending in three localities: Salt Lake County, Utah; Dallas, Denton, and Tarrant counties in Texas; and Santa Clara and San Mateo counties in California ("Silicon Valley"). ${ }^{1}$

This report builds on two previously published "how to" guides for individuals and organizations wishing to address payday lending with the tools available to local governments. The report adds breadth and depth to these guides by documenting several city-specific campaigns from start to finish. The report goes inside these campaigns through interviews with key leaders and their allies.

The overall report consists of five major parts. This, the first part, summarizes the entire project. We begin by arguing that local ordinances to restrict payday lending are part of a larger social movement. We then describe the contributions of two previous efforts to understand the components of successful ordinance campaigns. Next, we explain the methodology used in this report. We then discuss five basic components of ordinance campaigns and these components can vary, and we summarize the many impacts of ordinance campaigns. Finally, we provide recommendations for future campaigns to enact local payday ordinances and offer some concluding observations.

Behind this summary is a longer report with four additional sections. The first three sections provide our detailed findings regarding the campaigns in Salt Lake, Silicon Valley, and Dallas. ${ }^{2}$ The final section describes the impacts these campaigns have had on subsequent legal action, public opinion, the advocacy organizations themselves, and the individuals behind those organizations. We hope these additional details will be of interest in municipalities across the country where citizens wish to address payday lending and other issues through local ordinances.

\section{The New Fair Lending Movement}

We conceive of the anti-payday lending campaigns described in this report as part of a social movement that we call the New Fair Lending Movement (NFLM). One could argue that what we identify as a social movement is better understood as an alliance among organizations with overlapping interests in a large number of financial products: credit cards, checking account overdrafts, international remittances, payday and auto title loans, student loans, tax refund anticipation loans, rent-to-own services, car loans, and mortgages. Moreover, the people and organizations that constitute the NFLM as we identify it do not necessarily think of themselves as belonging to a new and distinct social movement. We contend, however, that the term "movement" is justified when individuals and organizations have worked together for more 
than twenty years on a coherent set of issues and created durable mechanisms of coordination. $^{3}$

The NFLM is an extension of what might be called the "old" or "original" Fair Lending Movement. This movement focused primarily on racial discrimination in housing markets and the pernicious effects of segregation and redlining. ${ }^{4}$ Although this movement's roots stretch back to before World War II, it blossomed in the late 1960s and 1970s and was strongly influenced by the Civil Rights Movement. ${ }^{5}$ The NAACP and the Leadership Conference on Civil and Human Rights are venerable members of this movement (and continue to be important in pursuing fair lending today). This movement's major achievements include passage of the Fair Housing Act in 1968, the Equal Credit Opportunity Act in 1974, the Home Mortgage Disclosure Act in 1975, and the Community Reinvestment Act of 1977.

The growth of the markets for subprime mortgages as well as payday, auto title, and tax refund anticipation loans during the 1990s precipitated the New Fair Lending Movement. 6 Although communities of color are often targeted by these lenders, the NFLM views fair lending as a challenge for a wider swath of the population than its predecessor movement. For example, members of the armed services, regardless of race and ethnicity, often find themselves trapped in high-cost loans, even after an interest rate limit of $36 \%$ was set by 2006 federal legislation. Senator Elizabeth Warren, perhaps the most prominent member of the NFLM, has attempted to frame fair lending as a problem of the working class and the middle class. ${ }^{7}$ The NFLM goes beyond an attack on racial discrimination to a more generic critique of products whose cost is viewed as outrageous and whose structure virtually assures that loans blow up the budget of borrowers (e.g., adjustable rate mortgages with no down payment and minimal underwriting).

Whereas the NFLM made some progress prior to the Financial Crisis that peaked in 2008, (e.g., North Carolina's 1999 law limiting mortgage fees and banning prepayment penalties; the federal Fair and Accurate Credit Transactions Act of 2003; Georgia's 2004 ban on payday loans; the Military Lending Act of 2006) most of the gains occurred after the economic meltdown. The signal achievement of the new movement was the creation of the Consumer Financial Protection Bureau as part of the Dodd-Frank Wall Street Reform and Consumer Protection Act of $2010 .^{8}$ Other victories at the federal level include passage of the Credit CARD Act in 2009 and the announcement by the Internal Revenue Service in 2010 that it would no longer facilitate refund anticipation loans by providing tax preparers with a "debt indictor" showing whether a filer owed back taxes or other debts.

The participants in the NFLM are far more varied than those in the original Fair Lending Movement. Some organizations that take part in the NFLM, such as the National People's Action and Woodstock Institute, have their roots in the 1970s, and they retain a strong emphasis on racial equality in mortgage lending. Others, such as the Center for Responsible 
Lending, and the National Community Reinvestment Coalition, are newer but grow out of the same mortgage-focused tradition. These organizations have, however, broadened their concern beyond mortgages to other financial products that "strip wealth" in communities of color. ${ }^{9}$ Other participants in the NFLM, including Consumers Union, Consumer Federation of America, and National Consumer Law Center, have a long-standing record of attention to fair lending in both mortgage and non-mortgage markets.

Interestingly, the NFLM has attracted the participation of organizations with little or no ties to the original Fair Lending Movement: religious organizations, credit unions, social service agencies, youth leadership groups, research centers, and community foundations. The organizational breadth of the NFLM is exemplified in a recent letter to Richard Cordray, director of the Consumer Financial Protection Bureau. The letter, which urged promulgation of a strong payday lending rule, was signed by $\underline{762}$ civil rights, consumer, labor, faith, veterans, seniors, business, and community organizations from all fifty states. ${ }^{10}$

The NFLM is largely decentralized, but there are three mechanisms for information sharing and coordination. First, since 1999, there has been a listserv related to payday lending activity around the country. It began with six participants and now has approximately four hundred participants representing two hundred organizations. ${ }^{11}$ Second, beginning in 2004, there has been an annual "summit" for activists interested in high-cost credit issues. The summit takes place in early December in Washington, DC, and it draws organizations from across the United States. The meeting provides an opportunity to learn from peers about their efforts to influence public policy at the local, state, and federal levels. (Both the listserv and summit have been facilitated by the Consumer Federation of America.) Third, in 2009, Americans for Financial Reform was established as a broad coalition to spur passage of the Dodd-Frank Act, at which it succeeded, but has continued to mobilize federal, state, and local organizations in the pursuit of fairness to consumers and investors. ${ }^{12}$

Whether the local campaigns described in this report are considered part of a larger social movement or part of a long-term alliance among organizations from several existing social movements, the anti-payday loan campaigns we describe here are not isolated phenomena. These three campaigns are embedded in a larger effort to curb payday (and other high-cost loans) in other localities as well as in state and federal fora. This larger payday loan reform effort, in turn, is part of a still larger struggle for fair lending across a wide swath of financial products. Thus, the campaigns documented in this report represent instances of powerful and inspiring citizen engagement, the importance of which goes beyond the local ordinances they helped enact. 


\section{Prior Action-Oriented Reports}

Two previous reports have made important contributions to understanding, at a practical level, how local payday ordinances are enacted. The first of these reports, Controlling the Growth of Payday Lending Through Local Ordinances and Resolutions, was published in 2007 when few ordinances existed in California and Utah, and none in Texas. ${ }^{13}$ Many of the ordinances set minimum distances between two payday lenders (or other high-cost lenders) or between a lender and homes, schools, churches, or other non-commercial land uses. The authors-Kelly Griffith of the Southwest Center for Economic Integrity in Arizona, Linda Hilton of the Coalition of Religious Communities in Utah, and Lynn Drysdale of Jacksonville Area Legal Aid in Floridadrew on their first-hand experience to offer a guide for community consumer advocates and government officials interested in curbing payday lenders in local communities and at the state level. The authors provided general advice under headings such as "Learn all you can about payday lenders in your area" and "Learn what system your city or town has in place for passing ordinances." The report's most notable contribution was a detailed appendix that summarized payday lending zoning ordinances state-by-state. The authors updated the appendix several times, most recently in 2013. ${ }^{14}$ The various versions of this appendix have been cited and reproduced numerous times by payday loan supporters and opponents alike. ${ }^{15}$

In 2013, Tim Lohrentz of the Insight Center for Community Economic Development produced a second guide for people interested in passing municipal ordinances to limit payday lending. ${ }^{16}$ The report, Tools for Advocates of Limiting Payday Lending, provided more detailed advice. Lohrentz drew on his own experience and the input of other California-based advocates to provide specific examples of how to conduct background research, create a campaign work plan, build a coalition, and frame the issues in a way that will appeal to the general public and policy makers. The report is most useful in detailing the steps needed to document the number, location, density, and corporate headquarters of payday lenders in a particular community, as well as the cost (annual percentage rates) of the loans. The report's treatment of campaign dynamics, including coalition building, gathering testimony from payday borrowers, and issue framing, is more cursory.

Despite the indisputable value of these two reports, neither covers important subjects such as generating campaign resources (human and financial), building favorable media coverage, finding a champion within the city council and communicating with other city officials, or defusing the arguments made by ordinance opponents. This report seeks to fill these gaps in the understanding of how successful payday lending campaigns are waged at the local level. 


\section{Report Methodology}

\section{Research Site Selection}

There were approximately 160 local ordinances addressing payday lending at the end of 2013, with at least one local payday ordinance in twenty-five states. ${ }^{17}$ California had the most ordinances (25), and several states had only one. Some ordinances complement strong state restrictions on payday loans (e.g., Arizona, Oregon), while others function as a substitute for

them (e.g., Kansas, Wisconsin). ${ }^{18}$ The ordinances themselves vary in nature from short-term moratoria to limits on the location, number, density, appearance, and/or business practices of payday lenders. Some ordinances refer only to payday lenders, while others encompass several types of high-cost, small-dollar lenders (e.g., auto title loans). Some ordinances were the result of a prolonged and uphill battle, while others passed quickly and easily. Each campaign, however, constitutes its own story, with its own heroes/heroines and plot.

This study analyzes campaigns in three locations: Salt Lake County in Utah, Dallas, Denton, and Tarrant counties in Texas, and the Silicon Valley counties of San Mateo and Santa Clara in California. The ordinance campaigns in each location are important in their own right, but they also serve as useful contrasts. Utah has some of the earliest ordinances in the United States and the third most of any state, an unlikely distinction given Utah's conservative political environment. California has the second largest number of ordinances and also some of the most stringent that can be devised using only standard zoning methods (e.g., separation requirements and density limits). Texas has the most payday ordinances in the nation, but, more important, most of these ordinances go beyond zoning restrictions. The Texas ordinances of interest in this report regulate payday loans and the payday lending process (e.g., limiting the amount of the loans to $20 \%$ of gross monthly income). Unlike liberal California, Texas is a politically conservative state, making it an unlikely locale for some of the strongest local ordinances in the country.

In sum, by focusing on Utah, California, and Texas, this report covers the three states with the most local payday ordinances. In addition, the Salt Lake, Silicon Valley, and Dallas areas served as the epicenter for local anti-payday lending activity in their respective states. Despite these similarities, the three locales analyzed in this report provide an instructive contrast in terms of their political environments, their ordinance campaigns, as well as the nature of their ordinances.

\section{Data Sources}

The findings of this study are based on two major sources of information: documentary research and structured interviews. The documentary research included analysis of campaign 
materials produced by the advocates in each location, reports and minutes generated by planning commissions and city councils, press coverage of the ordinance campaigns, and the ordinances themselves. The interviews were conducted with campaign participants in each of the three research sites. The interviewees included advocates in non-profit organizations as well as government policy makers and reporters and editors at leading local newspapers. The interviewees were recommended by a key informant in each location (Linda Hilton in Utah, Ann Baddour in Texas, and Rafael Morales in California). These key informants provided interviews as well.

The majority of the interviews were conducted in-person and on-site, with a few taking place by phone. Similarly, the majority of interviews took place with a single interviewee, but some interviews involved more than one interviewee at a time. Both researchers were present for all of the interviews except two. In all, there were thirty-two interviews: seven in Utah, thirteen in Texas, and twelve in California. ${ }^{19}$ Interviews lasted 60-90 minutes, were audio-recorded, and were later transcribed. ${ }^{20}$

\section{Campaign Features}

The dynamics of the payday ordinance campaigns analyzed for this report varied substantially based on the individual and organizational actors, legal frameworks, and political opportunities present in each locale. By examining these differences (as well as several important commonalities), it is possible to appreciate the multiple pathways through which local payday ordinances can be successfully pursued. In this section, we address five general features that are common to but not uniform in all three of the campaigns we studied: (1) leader motivation, (2) campaign resources and coalition building, (3) outside and inside politics, (4) addressing opposition, and (5) policy diffusion.

\section{Leader Motivation}

There is a robust social science literature on the diffusion of public policies, but far less is known about how policies originate. ${ }^{21}$ For example, once California legalized medical marijuana in 1996 and the policy survived federal legal challenges, it was relatively easy for Oregon, Maine, Nevada, Colorado, and Montana to follow suit in the next decade. ${ }^{22}$ The compelling question is: how did California become the policy innovator? With respect to local payday ordinances, there are similar questions about the policy innovators. How did these ordinances first come about in the Salt Lake, Dallas, and Silicon Valley areas? Who provided the leadership to overcome the force of policy inertia? Is each case of "policy entrepreneurship" idiosyncratic, or are there commonalities? ${ }^{23}$ 
We observed one or more policy entrepreneurs in each of our three study sites. While there are others as well, these policy entrepreneurs included: Christopher Peterson and Linda Hilton in Salt Lake County; Ann Baddour, Jerry Allen, Gerald Britt, Jr., and Kayce Strader in the Dallas area; and Eleanor Clement Glass and Pat Krackov in the Silicon Valley. What sparked the interest of these individuals in payday lending reform, and what sustained them as they campaigned?

Exposure to the realities of payday lending served as the motivating force for most of the campaign leaders we interviewed. Law professor Christopher L. Peterson of the University of Utah had experienced these loans first-hand. After finishing college and to earn money for some foreign travel, Peterson worked as a telephone-based debt collector for a company that made payday, car title, and other loans to subprime borrowers. The young Peterson took the job without knowing much about the payday loan industry, but perhaps should have been tipped off when his boss described himself without shame as a "loan shark." After a few months of calling delinquent borrowers, Peterson could no longer stomach the job. The people on the other end of the phone line, often weeping, described a pattern by which they paid significantly more than they had borrowed yet could not seem to retire their debt. Peterson saw that his company's loans were making its customers worse off, and this lesson had a profound effect on his subsequent activities as a law student and then legal scholar. Most important for this report, it led him to suggest to his mother, a member of the city council of West Valley City, the possibility of passing a zoning ordinance aimed at limiting the number of payday lenders. $^{24}$

One step removed from Peterson's experience inside the payday industry was exposure to payday borrowers in the context of social service agencies serving the poor. Whether Linda Hilton at Utah's Crossroads Urban Center, Christian Luna at Sacred Heart Community Service in San Jose, or Katie Murray at the Wilshire Baptist Church in North Dallas, our interviewees were activated by hearing the stories of payday customers, including exorbitant interest rates as well as the pattern of extending ("rolling over") loans over and over again without making a dent in the loan balance. People working in social service agencies were angered further by the realization that the financial assistance they gave to clients to settle a utility bill might be going instead to a payday lender.

For other advocates we interviewed, second-hand exposure to payday practices was sufficient to mobilize them. Reverend Gerald Britt was familiar with social injustice, but he recalled the radicalizing effect of reading the book, Broke, USA by Gary Rivlin in 2010, and writing a review of it for the Dallas Morning News. ${ }^{25}$ Kayce Strader was appalled when she first heard about payday lending at a 2012 conference on addressing problems of poverty from a Christian faithbased perspective. As Strader exited the conference session, she ran into her colleague Pat 
Smith in the hallway, and he thought she looked ill. Smith asked Strader if she was O.K. Strader answered that she was, but she informed Smith that she knew what the two of them had to do when they returned from the conference. ${ }^{26}$ Strader had become aware of a serious injustice, and her Christian faith impelled her to act.

The process by which leaders of Silicon Valley Community Foundation (SVCF) became devoted to addressing payday lending was far more systematic than Strader's nearly accidental encounter. SVCF's prioritization of payday lending was the result of an intensive project of obtaining input from members of its community-leaders of non-profit organizations, members of the public at large, government officials, and foundation donors. ${ }^{27}$ From an initial list of nine topics that emerged from these community listening sessions, SVCF's leaders selected five areas of highest priority. One of these was "economic security," and it encompassed antipredatory lending advocacy. ${ }^{28}$

Finally, city council members such as Mike Guingona in Daly City, California and Jerry Allen in Dallas, Texas were moved to action through a combination of devotion to their low-income constituents and exposure to the arguments of payday advocates. In Guingona's case, he was the first Filipino American elected to the city council of Daly City, and he was sensitive to the problems of low-income and minority citizens. When Guingona saw that young people of color in his community-themselves shocked by discovering a payday lending machine in a local casino-were willing to fight against payday lending, he felt compelled to mentor them in pressuring the city council and conducting his own inside lobbying.

Dallas City Councilman Jerry Allen, too, felt a responsibility to represent the interests of his economically diverse district. In the aftermath of the economic meltdown of 2008, Allen became acutely interested in anti-poverty measures. He was especially impressed by the goal of the Anti-Poverty Coalition of Greater Dallas to lift 250,000 families out of poverty within ten years. As a former banker, he understood the importance of access to financial services, and he became a champion for the "Bank on Dallas" program as a way of moving people away from the expensive check cashers and payday lenders.

The pivotal moment in Allen's antipathy for payday lending came on June 16, 2010, the day on which the Bank on Dallas program was to be launched at a press conference held at City Hall. The media attention Allen hoped to garner was stolen that morning when the Dallas City Council presented an award to the payday lender ACE Cash Express for providing humanitarian aid to the Red Cross to assist earthquake victims in Haiti. It was difficult for Allen to see ACE being praised for its community outreach efforts via a proclamation of the Dallas City Council when his program needed the attention. Allen felt the upstaging was deliberate. At that point, it was "game on" as far as Allen was concerned. ${ }^{29}$ 
In sum, exposure in various forms to the details and human impact of payday lending served as the main galvanizing force for the advocates we interviewed. Exposure was a necessary condition for leadership commitment, but it was typically part of a larger commitment to social and economic justice. This commitment was sometimes secular, sometimes based on religious faith. Either way the advocates we studied had a passion for reform that sustained them beyond a single, initial victory. Most of them remained devoted to seeing local ordinances spread to other communities and for these ordinances to be part of a larger effort to enact state and federal policies.

\section{Campaign Resources and Coalition Building}

Resources are so crucial to the success of social movements that one of the leading sociological perspectives on social movements is called "resource mobilization theory." The essence of this theory is that grievances and injustices are often insufficient to generate a social movement. Rather, movement leaders and their organizations must be able to gather sufficient financial, human, communication, and other resources to participate in the political process. McCarthy and Zald, two of the pioneers of resource mobilization theory, noted that social movements are not limited to obtaining resources from the people who stand to benefit directly from movement actions; resources may come from "conscience adherents" and "conscience constituencies" composed of people and organizations motivated more by ethics than economics. ${ }^{30}$ These conscience constituencies might include idealistic or affluent individuals as well as "private foundations, social welfare institutions, the mass media, universities, governmental agencies, and even business corporations." ${ }^{31}$ If older theories of social movements helped explain broad-based and even violent forms of collective behavior such as the French or Chinese Revolution, resource mobilization theory attempted to explain more institutional and reformist movements such as the environmental, consumer, women's, or antiVietnam War movements.

The campaigns to pass local anti-payday lending ordinances in the Dallas and Silicon Valley areas were well-resourced but in very different ways. In Dallas, Denton, and Arlington, Texas, coalitions composed of social service agencies, religious organizations, and anti-poverty organizations mobilized mostly in-kind resources in the form of personnel time. For example, Stephanie Mace, director of public policy for the United Way of Metropolitan Dallas, devoted a large portion of her time during the final months of 2010 and the first half of 2011 serving on the steering committee of the Anti-Poverty Coalition of Greater Dallas. Other organizations, including CitySquare, AARP, the Industrial Areas Foundation, and the Jewish Community Relations Council, lent some of their key leaders to the ordinance effort. Members of these organizations drew upon prior knowledge of each other to build a coalition that crossed lines of income and race. Similar coalitions, although smaller and less broad-based, were instrumental 
in the passage of ordinances in other Dallas-area cities. The overall lesson to be drawn from the Dallas-area experience is that a successful campaign can emerge organically from a coalition of local organizations dedicated to social justice and relying primarily on a shared workload rather than abundant financial resources.

In Silicon Valley, a community foundation catalyzed the participants in a series of local campaigns that might not have occurred without the foundation's active role and generous financial support. Based on an intense community consultation process, Silicon Valley Community Foundation (SVCF) identified local payday lending ordinances as a priority for action. From there, SVCF used its grantmaking process to intensify the activities of organizations that were already engaged in payday lending reform (e.g., California Reinvestment Coalition) and, equally important, bring new organizations into the arena (e.g., Youth Leadership Institute; Law Foundation of Silicon Valley). In Santa Clara County, SVCF funded an explicit effort to create the Coalition Against Payday Predators (CAPP). Between 2009 and 2015, SVCF provided more than a million dollars to the Law Foundation of Silicon Valley, partly to support CAPP. ${ }^{32}$ In neighboring San Mateo County, SVCF made grants to individual organizations without attempting to build a formal coalition, but the San Mateo grantees were in frequent contact with each other, often facilitated by meetings and conference calls convened by the Foundation.

SVCF's funding not only stimulated formal and informal coalitions; it deepened the capacity of the participating organizations. For example, SVCF held training sessions for its grantees. It also provided funding for public opinion research on payday lending and focus group research on ways to most effectively deliver anti-payday messages to members of the public and to policy makers. ${ }^{33}$ SVCF also provided funding to the Insight Center for Community Economic Development to develop a "toolkit" for advocates based in the Silicon Valley and elsewhere who might be interested in mounting their own local campaigns. Between 2009 and 2016, SVCF allocated approximately $\$ 4$ million to its program on anti-payday lending policy advocacy at the local and state levels, making SVCF the ultimate "conscience constituency."

\section{Outside and Inside Politics}

Like basketball superstar LeBron James, it is important for advocates to have both a strong "outside game" and a powerful "inside game." ${ }^{34}$ The outside game consists of building public support for one's position, whereas the inside game concerns influencing the views and votes of public policy makers. Effective messaging is integral to both efforts.

The advocates in the Salt Lake, Dallas, and Silicon Valley areas played the outside and inside games well. In all three locations, the advocates cultivated a supportive relationship with the local media, especially the leading mass circulation newspapers. In Salt Lake, quotations from 
Linda Hilton of the Coalition of Religious Communities found their way into most payday lending articles in the two leading daily papers, The Salt Lake Tribune and Deseret News. In Dallas and Silicon Valley, advocates enjoyed not only news coverage but were also invited to submit guest columns. Meetings with newspaper editorial boards were often followed by editorials expressing strong support for local ordinances.

Advocates in the Dallas and Silicon Valley areas proactively used social media as well. For instance, news about payday lending reform was frequently posted on the websites of the California Reinvestment Coalition and the Center for Responsible Lending. In Dallas, the AntiPoverty Coalition held a press conference, featuring leaders of the local Baptist and Catholic communities. In the Salt Lake area, the payday campaigns were carried out by the Coalition of Religious Communities - an anti-poverty alliance of fifteen different faith communities. Thus, in Utah and Dallas, where religion looms large in public life, the identification of payday lending reform with faith leaders was an important element of campaign messaging.

Inside lobbying is designed to close the deal, that is, get members of planning commissions and city council to vote for local payday ordinances. To this end, advocates employed a number of methods. The most basic form of inside lobbying is meeting privately with decision makers. Whereas these decision makers often attend alone or with just a handful of staff members, advocates are able (and advised) to bring representatives of multiple constituencies. Advocates also need to be sensitive to the kinds of arguments that are most likely to resonate with a particular policy maker. In some cases, as best represented by Salt Lake County in this study, policy makers are most receptive to arguments about the negative economic impacts of payday lending, especially the impact of too many stores on the image of a city. In other instances, and as represented by the Dallas and Silicon Valley areas in this study, government officials are more receptive to moral/social arguments about the devastating impact of payday lending on the lives of some borrowers.

Another fundamental tactic of inside lobbying is to testify at public hearings. Whereas representatives from religious, social service, and advocacy organizations are important, garnered testimony from borrowers who have suffered due to payday loans is probably the most effective method of pressuring policy makers in public settings. This type of testimony puts payday lending supporters on the defensive and perhaps explains why representatives of the payday industry often do not speak at public hearings.

Some methods of inside lobbying are more specific to payday lending per se. In the Dallas area in particular, advocates were successful in getting some city councils to issue resolutions urging state legislators to enact strong payday reforms. From the point of view of the city councilmembers, such resolutions carry few political risks since they change nothing on the ground when it comes to payday lending, but they do put a councilmember on record as 
favoring payday reform. After encouraging action by state lawmakers, it may be difficult later for councilmember to vote against a local ordinance.

As a final and unusual example of inside lobbying, SVCF provided a $\$ 50,000$ grant to the City of San Jose in 2011. City leaders had complained that they lacked the financial resources to devote staff time to research payday lending practices in San Jose or analyze reform options. SVCF eliminated the city's concern by directly providing funds to the city for the research. ${ }^{35}$ While most campaigns don't have $\$ 50,000$ they can devote in this way, SVCF's grant was an innovative way of advancing payday lending in the city council's policy agenda.

Inside lobbying is most effective when it is coordinated with the persuasion efforts of someone inside the government decision-making body. In Dallas, councilmember Jerry Allen was eager to work with the members of the Anti-Poverty Coalition. The same was true of Ash Kalra in San Jose. In Daly City, Councilmember Mike Guingona tutored the members of the Youth Leadership Institute on how to communicate with city leaders. While having an inside champion such as an Allen, Kalra, or Guingona is ideal, advocates and policy makers need to maintain both the appearance and reality of independence from one another for the sake of credibility.

\section{Addressing Opposition}

In the vast majority of city councils (and county boards of supervisors) examined in this report, most votes ended up being unanimously in favor of payday ordinances, but this does not mean all of these votes were cast eagerly. Most decision makers hold private meetings with payday industry representatives (just as they have with ordinance supporters) and are warned about the loss of jobs and tax revenue that result from discouraging payday lenders. These decision makers also are told that payday loans meet a legitimate need, and without them, consumers will end up paying more for credit and possibly having to patronize illegal loan sharks. In some cases, payday supporters cite research to add weight to their arguments. On top of all this, some city council members are philosophically averse to meddling in freely-chosen contracts between lenders and borrowers. For all these reasons, ordinance advocates must be prepared to defend their proposals against pro-industry arguments.

Pointing out the high cost of payday loans and the cycle of debt in which many borrowers find themselves does not address the argument that borrowers would be even worse off without access to payday loans. Accordingly, advocates must be prepared to argue that short- and longterm alternatives to payday loans are available. In San Mateo County, Board of Supervisors member Rose Jacobs Gibson developed and disseminated a guide to payday loans, including a description of alternatives to them. In terms of coping with a financial emergency, the brochure recommends negotiating directly with creditors, obtaining advances from employers, 
and seeking emergency assistance from faith-based and community organizations. The guide also discusses lenders other than payday firms, including credit unions, non-payday internet lenders, and lending circles. ${ }^{36}$

To further awareness of payday alternatives, SVCF co-sponsored a conference in December 2010 with the Federal Reserve Bank of San Francisco. The conference attracted leaders of financial institutions, social service agencies, policy institutions and government who were interested in learning about payday loans and alternative products. ${ }^{37}$ Later that month, Dr. Emmett D. Carson, SVCF's president and CEO, discussed payday loan alternatives on one of the Bay Area's most popular radio stations, KQED. ${ }^{38}$ In the immediate run-up to the discussion of a possible ordinance by the San Jose Planning Commission and City Council in 2012, CAPP ran a public forum called "When Cash Runs Out: Discussing the Alternatives." ${ }^{39}$

The City of Sunnyvale, as part of its payday lending ordinance, requires payday lenders to post a clearly visible sign that provides alternatives to payday loans. ${ }^{40}$ As a practical matter, most people who are standing at the threshold of a payday lending store are probably not seriously considering alternatives, but the sign's information and implicit message might make a difference the next time a person is considering a payday loan.

In terms of alternatives to payday loans, California advocates stressed the importance of consumer education and asset building. These values were reflected in SVCF's public pronouncements and, perhaps more important, in its grant-making. In the spring of 2011, when only Pacifica had a payday lender moratorium and no other cities yet had ordinances, Emmet Carson, was quoted as saying: "The financial literacy piece of this is the core. I can't stress that enough. You need to understand how to budget, the appropriate uses of credit, and cash flow." ${ }^{41}$ One SVCF grant to promote payday alternatives was made in 2012 to Community Legal Services in East Palo Alto for supporting a local ordinance and conducting "a corresponding community education effort to curb voluntary use of these financial products." 42 Another SVCF grant went to Housing and Economic Rights Advocates in 2015 for "increasing community-wide awareness of the various alternatives to payday lending." 43

In Texas, too, advocates such as Gerald Britt emphasized educational opportunities, job training, and a living wage as the ultimate substitute for payday loans. ${ }^{44}$ In August 2016, Texas Appleseed published A Toolkit for Cities: Increasing Access to Fair, Low-Cost Loans. ${ }^{45}$ Unlike the 2013 toolkit underwritten by SVCF, this one urged cities to do more than pass local ordinances that restrict payday lending. This toolkit urged cities to encourage low-cost loan products such as employer-based loans as short-run alternatives to payday loans and promote community asset building services to obviate the need for loans in the longer run. 


\section{Policy Diffusion}

Between 2002 and 2016, thirty-two zoning ordinances and eight business regulation ordinances were enacted in the three metropolitan areas covered in this report. These forty ordinances also helped stimulate passage of additional ordinances in their respective states. Thus, one ordinance can beget others, especially if it is one of the first in its jurisdiction (as was the case in Dallas and West Valley City, Utah).

How does diffusion of ordinances occur? In this study we observed two processes-one reactive, the other more proactive. In Utah, once West Valley City passed its ordinance in 2002, neighboring cities such as Taylorsville, West Jordan, South Salt Lake, and Salt Lake City felt pressure to enact their own ordinances to prevent payday lenders from setting up new outlets on their borders adjacent to West Valley City. This defensive strategy rippled through Salt Lake County and eventually established a model for more distant communities in Utah.

In Dallas and Silicon Valley, the transmission of ordinances was more deliberate. The City of Dallas broke the ice in 2011 when it passed its business regulation ordinance. Thereafter, Dallas City Councilmember, Jerry Allen, who led the effort within the Council to pass the ordinance, adopted the role of Johnny Appleseed, visiting any town in Texas to which he was invited to speak in favor of a Dallas-style ordinance. ${ }^{46}$ Within two and a half years of passage of Dallas' ordinance, the three other largest cities in Texas (\#1 Houston, \#2 San Antonio, and \#4 Austin) passed similar laws. While Allen barnstormed the state, the Texas Municipal League circulated a model ordinance based on those passed in Dallas, Austin, and San Antonio. The League recommended that cities considering adoption of a payday ordinance enact one that was substantially similar to those already passed. By passing similar ordinances, the League predicted that payday lenders "will not be able to use the argument that city ordinances vary from city-to-city if they seek preemption legislation [from the Texas Legislature]."

The proliferation of payday ordinances in California was central to SVCF's anti-payday strategy. SVCF's financial support for a how-to "toolkit" for passing ordinances illustrates SVCF's strategy of encouraging as many local laws as possible. Its support of the Youth Leadership Institute's work to pass an ordinance first in Daly City and then in South San Francisco is a further example. ${ }^{48}$ In all three locales covered in this report, passage of an ordinance in one city tended to embolden leaders of other cities. In Salt Lake County and Silicon Valley, not having an ordinance became the exception. In the Dallas area, several cities chose not to enact ordinances, but the Dallas ordinance was adopted by nearly thirty other cities statewide. 


\section{Campaign Impacts}

Local zoning ordinances are, of course, a limited tool for addressing the problems associated with payday lending. While many advocates reported that their local ordinances reduced the numbers of loans and lenders in a particular area, causation issues make these claims difficult to substantiate with hard data. While these ordinances may reduce the supply of loans available through brick-and-mortar outlets over the long run, the ordinances' most significant impacts are more intangible. First, these campaigns can encourage stronger regulatory action from state and federal governments, and they can signal to marketplace actors that payday alternatives are needed. Second, as local ordinance campaigns receive media coverage and, in some instances, generate their own public messages, members of the public receive are exposed to largely negative information about the payday industry. And as one local ordinance campaign begets others, each serves as a further blow to the public image of payday lenders. Finally, local ordinance campaigns can have beneficial side effects for their participants in terms of stronger organizational capacity and greater sense of individual empowerment. ${ }^{49}$

\section{State and Federal Action}

Campaigns for local ordinances are viewed by their participants as either substitutes for state action or as spurs to it. The passage of Dallas's business practices ordinance came only a few weeks after advocates realized that the Texas Legislature was not going to enact strong statewide protections. ${ }^{50}$ Similarly in Utah, the perception among payday lending's opponents that the Utah Legislature was in the pocket of the payday industry suggested a second-best strategy of seeking local reforms. ${ }^{51}$

In California, SVCF viewed the passage of local ordinances in numerous jurisdictions as both an end in itself and as a means of building support for state- and federal-level action. In its first request for proposals, SVCF stated that "[i]n the long term we seek to contribute to state level reform by supporting advocacy efforts aimed at passage of a cap on payday loan interest." 52 Accordingly, grant applicants were encouraged to describe how their policy advocacy would "lead to meaningful reforms at the local level and build a constituency for state level reform in the future." 53

Over time, SVCF also made grants that included support for the payday rule-making process at the U.S. Consumer Financial Protection Bureau. The Foundation's 2014 grant to the Center for Responsible Lending included the goal of encouraging "the Consumer Financial Protection Bureau to strengthen its regulatory oversight to end the payday debt trap." ${ }^{154}$ In the same grant cycle, SVCF awarded funds to the Youth Leadership Institute, in part, to "push federal 
legislation to regulate the [payday] industry and advocate for quality youth financial products." 55

Moving from local to state or federal advocacy also occurred in the absence of a foundation grant. In Dallas, Reverend Britt of CitySquare and the Anti-Poverty Coalition expanded the scope of his advocacy to include support for the CFPB's efforts to regulate payday lenders. ${ }^{56}$ The same was true of Councilmen Allen. ${ }^{57}$ In California, Daly City Councilmember Mike Guingona was not content with leading the way in passing a local ordinance in his city. He also wrote a letter to the CFPB urging it to enact payday lending reform. ${ }^{58}$ In sum, once aware of the dangers of payday lending, advocates and local policy makers often felt compelled to work toward policy improvements at higher levels of government.

\section{Public Awareness and Opinion}

Media coverage of local campaigns to enact payday ordinances most likely influenced public opinion regarding payday lending, but ordinance advocates did not collect survey data regarding public awareness and sentiment. The one exception was a survey conducted by Goodwin Simon Strategic Research in November 2010 for the Center for Responsible Lending. The survey found that only $17 \%$ of registered voters in San Jose had favorable views regarding payday lenders, compared to $52 \%$ holding a negative opinion. In addition, respondents tended to be favorable toward additional restrictions on payday loan stores-restrictions that were being sought by the CAPP at the time. There is no post-ordinance survey that can be used to measure the possible impact of the ordinance campaign on public opinion in San Jose, let alone a before-after comparison in a comparable city without an ordinance campaign.

In the Silicon Valley, there were several efforts to influence public awareness of and sentiment toward payday lending after the successful completion of several ordinance campaigns. Shortly after passage of the San Jose ordinance, for example, CAPP purchased advertisements on the sides of buses that circulated throughout Santa Clara County. ${ }^{59}$ A more personal and individualized effort to influence public opinion regarding payday lending was undertaken through financial education classes. Community Legal Services of East Palo Alto (CLESPA), Nuestra Casa, and the entrepreneurship-oriented Renaissance Mid-Peninsula offered consumer education classes to help people develop financial skills and thereby reduce the need for payday loans. In a particularly creative instance, Nuestra Casa incorporated education about payday lending into a class for undocumented residents seeking a driver's license under a new California law. The theory behind including payday lending education was that getting a license involves buying a car, and buying a car entails understanding credit, and understanding credit includes avoiding high-cost forms of borrowing such as payday loans. ${ }^{60}$ 
While we cannot measure the impact of efforts to influence public opinion with any certainty, advocates believe that their efforts contributed to a marked cultural shift in the way payday lending is viewed by their fellow citizens. As Reverend Britt of Dallas CitySquare stated:

We have been a significant voice bringing payday lending to the public consciousness, and we've actually changed the conversation about payday lending and about financial literacy and the need for financial literacy, not just among lower to middle class people, but for everybody. I don't think that that would have happened if we hadn't done this. ${ }^{61}$

In California, James Zahradka, formerly of the Law Foundation of Silicon Valley, reported that his coalition's efforts created a cultural sea change in which lenders were associated with societal ills. Zahradka explained the importance of getting city after city on record saying that payday loans are toxic products, and while legal, they are still a problematic land use. He believes that by regulating payday lenders in the same way as a liquor store or adult bookstore, a city makes a powerful contribution to changing the national culture with respect to high-cost lending. ${ }^{62}$

\section{Organizational and Individual Capacity}

The campaigns we studied changed many of their participants. In particular, organizations developed new relationships and expanded their missions. Individuals empowered themselves politically and strengthened their religious beliefs via social action.

As discussed above, coalitions played a central role in all three campaign locales. Utah's Coalition of Religious Communities (CORC) existed for a few years before it made payday lending one of its two signature issues (the other being removing the state sales tax on food). The Anti-Poverty Coalition of Greater Dallas (APC) and the Silicon Valley's CAPP made payday reform their initial priority. In so doing, APC and CAPP brought together diverse organizations with limited history of working together. As a result of their ordinance efforts, these organizations developed a durable spirit of cooperation. Consider the case of Dallas where the first ordinance was passed in 2011. In 2013, Friendship-West Church, with predominantly Black members and located in economically-challenged South Dallas, formed a "covenant of action" with Wilshire Baptist Church, with predominantly White and affluent members, to continue the battle against payday lending. ${ }^{63}$ Their covenant commits Wilshire and Friendship-West to act "jointly to confront predatory lending practices that disproportionately harm the vulnerable ... by educating our churches, advocating for more just laws, and creating alternative credit sources that promote the welfare of the lenders and borrowers alike." ${ }^{14}$ 
Several organizations reported that their mission was expanded to include policy advocacy by virtue of participating in a local ordinance movement. For example, Christian Luna of Sacred Heart Community Service in San Jose said that as a result of his organization's advocacy work around payday lending, Sacred Heart became more than a direct service provider; it became an advocacy organization. ${ }^{65}$ Similarly, Kyra Kazantzis of the Law Foundation of Silicon Valley said that her organization had been affected by the process of working on payday lending reform. The experience taught the Law Foundation how to do a sustained, sophisticated, and coalitionbased policy campaign and led the organization to more prominently prioritize collaborative action. Regarding the Silicon Valley Council of Nonprofits, Kazantzis observed that it, too, had been changed by being an official endorser of CAPP. ${ }^{66}$ She said: "Payday lending really solidified, in that entity's mind, that nonprofits should absolutely be doing policy advocacy." ${ }^{67}$

Individual empowerment occurred in parallel with the new relationships and expanded missions that developed for organizations that took part in ordinance campaigns. This process of empowerment applied to members of advocacy organizations who championed payday borrowers as well as to borrowers themselves. In Utah, Art Sutherland was a semi-retired engineer who was looking for a way to use his talents to help society. Beginning in 2005, he volunteered to help CORC with its anti-payday advocacy. Little did he know that a decade later he would be honored by Money magazine as one of its "50 Heroes." 68 Another example involving much younger people comes from Silicon Valley where the anti-payday lending movement included two organizations that develop the leadership skills of youth. ${ }^{69}$ Through their campaigns against payday lending, the young people organized by the Youth Leadership Institute (YLI) and their partner Mission SF Community Financial Center (now MyPath) learned to identify social problems, find their own voice in community, and navigate the political process.

As yet another instance of individual empowerment, Danielle Ayers, Minister of Justice of Friendship-West Baptist Church described the feeling of her church members after helping to enact Dallas' payday ordinance. Ayers reported that members "were encouraged and felt empowered. They felt that they had succeeded at something that there was good news."70 These congregants retained the ability to mobilize when a few years later a plant nursery located near the church closed and was replaced by a title lender. Through the church's advocacy, the lender was forced to leave after it opened for business. Then, the restaurant chain Raising Cane's moved in, creating a huge, visible victory for the community.

Ordinance campaigns also taught payday loan borrowers to become their own advocates. In Silicon Valley, Sacred Heart Community Services not only gathered stories from payday borrowers but convinced some of them to speak about their experiences with payday loans in 
front of the San Jose Planning Commission and City Council. Christian Luna, a program manager at Sacred Heart, remarked that this act of standing up for themselves and others like them helped borrowers grow as individuals and feel part of something important.

Stephanie Mace of the United Way of Metropolitan Dallas (Dallas United Way) recounted a process of political engagement with a group of people who will never need to take out a payday loan-United Way's largest donors. The United Way trained some of them to go to payday stores and pose as borrowers who wanted to take out a $\$ 500$ loan. Based on their experience as secret shoppers, the donors were encouraged to speak with state and local politicians about the need for changing the law to make these loans more transparent and affordable. $^{71}$

For some campaign participants, faith development rivaled political empowerment as an outcome for the many advocates who were motivated by their religious beliefs. Josephine Lopez Paul of the Industrial Areas Foundation in Dallas described a member of Father Dan Kelley's congregation at St. Joseph Catholic Church in Arlington as being surprised that she could be "a pretty effective speaker in front of the city council [while having] a way to live out my faith."72 Danielle Ayers called the same process "faith formation" and described how her Senior Pastor, Dr. Frederick D. Haynes, III, would urge parishioners to connect what they heard in church on Sunday morning with "how we live out our daily lives between Sundays.."73

On at least one occasion, the opportunity for faith development came suddenly and unexpectedly. As Walker Moore of the Industrial Areas Foundation recalled the events, Father Kelley at St. Joseph's Church attended a meeting of the Arlington Chamber of Commerce to speak in favor of a payday ordinance. To his surprise, the meeting was being chaired by one of his congregants, a "pro-business, anti-regulation guy" who would normally oppose regulating lenders. ${ }^{74}$ The councilmember now faced a conflict between his political and religious impulses, and he ended up taking no position on the proposed ordinance rather than opposing it. ${ }^{75}$ In this instance, voting on payday ordinances forced a political leader to live his faith in public.

In sum, payday ordinance campaigns are designed to convince city leaders to address a local problem, but these campaigns can have many additional impacts. The campaigns may stimulate political action at the state and federal level. They can influence public opinion and knowledge about not only payday lending but asset building as well. Participation in these campaigns can also affect their organizational and individual participants. Organizations can find themselves with new relationships and with an expanded mission that includes policy advocacy. Finally, individuals may become more politically empowered and spiritually fulfilled as a result of being part of a payday ordinance campaign. 


\section{Lessons for Future Campaigns and Conclusion}

The following is a list of key observations from the three jurisdictions analyzed in this report. The observations highlight key components of successful campaigns and, as such, provide guidance for other organizations and individuals who are planning ordinance campaigns in their cities (or counties).

Lesson \#1: Coalitions of organizations served as the coordinating mechanism for campaigns in all three locales analyzed in this report. The coalitions varied in the breadth of their membership and their resources, but they were central in all of the major campaigns. Forming coalitions and developing rules for their operation should be one of the first tasks of payday reformers.

Lesson \#2: Each of the leaders profiled in this report learned about the dark details of payday loans from borrowers themselves. Social service providers who were part of the coalitions played a crucial role in making contact with borrowers, gathering their stories, and empowering borrowers to tell these stories at public hearings.

Lesson \#3: Financial support from Silicon Valley Community Foundation was essential for running a highly sophisticated set of campaigns involving a broad range of organizations, but it was absent in Dallas and Salt Lake. In Dallas, a campaign of equivalent impact to that in Silicon Valley was mounted by a coalition of local organizations that lacked special funding but were able to reassign personnel to the payday campaigns. In Utah, the absence of financial and human resources resulted in a bare-boned but spirited effort by a handful of people. Advocates should not assume that ample financial resources are necessary for a successful campaign.

Lesson \#4: Including faith organizations in campaign coalitions and having faith leaders serve as figureheads adds enormously to campaign legitimacy in the eyes of the public and policy makers. Involve faith leaders in a meaningful and ongoing way early in any campaign.

Lesson \#5: Advocates in all three study locales successfully cultivated support from major local newspapers and, to a lesser extent, television stations. Media coverage, op-ed articles, and supportive editorials helped create a pro-reform climate that was difficult for policy makers to ignore. Advocates should have a detailed strategy for working effectively with members of the local media.

Lesson \#6: Advocates should identify and cultivate a member of the city council (or county board of supervisors) who will serve as their inside champion. This role includes mentoring advocates in the peculiarities of the local political process as well as lobbying fellow decision makers. In some instances, more than one potential champion may be available, making the choice of a champion especially delicate and important. 
Lesson \#7: Advocates should schedule meetings with city decision makers well in advance of any key votes. In these meetings, advocates should be ready to document the extent of payday lending in their communities and to present their arguments in favor of an ordinance. Because different arguments may resonate with different city decision makers, advocates must be ready to argue for payday ordinances on the basis of the loans' primary impact on borrowers and on their secondary impact on local economies, crime, blight, and the general image of the city.

Lesson \#8: Industry representatives will not always testify in public settings, but they will typically meet privately with sympathetic policy makers and express objections to local ordinances. Advocates must also be prepared to counter the arguments of their opponents, especially the notion that there are no alternatives to payday loans. If possible, advocates should develop a concrete list of payday alternatives that can be shared with members of the public as well as policy makers.

Lesson \#9: Once successful at the city level, advocates should press for similar ordinances in other cities. These additional ordinances should be similar to each other to forestall industry complaints that complying with differing laws is excessively burdensome. There are, however, opportunities, to add features that strengthen the basic ordinance as long as they do not contradict the features of other ordinances (e.g., limiting store hours of operation; requiring a sign inside the store that describes alternatives to payday loans).

Lesson \#10: Along with seeking additional local ordinances, advocates should continue to press for state- and federal-level reform. In this task, community groups are not alone. A national network of organizations already exists for the purpose of curbing payday lending and other forms of high-cost lending. Marked by an annual conference facilitated by the Consumer Federation of America, continuous communication via a listserv, and major policy successes, this network is for all intents and purposes a social movement.

In conclusion, no one ever claimed that enacting local payday ordinances would eliminate payday lending-let alone eliminate the economic and social conditions that drive people to resort to these loans. Nevertheless, campaigns in the three locales analyzed in this report clearly demonstrate that advocates and city leaders can do something meaningful, within the limits of their authority, to make a statement against payday lending. Their efforts have resulted in dozens of local ordinances that impose limits on the location, density, hours of operation, and, in the case of Texas, features of payday loans.

The campaigns have had a variety of beneficial secondary effects. The advocates helped build a climate for further reforms at the state and federal levels by contributing to a new narrative. This narrative confronts the payday industry's claim that their loans, while expensive, meet an 
urgent need when no other options are available. This narrative defines payday loans as dangerous "debt traps" to which society has an obligation to build better alternatives.

Beyond any impact on payday lending itself, the campaigners changed others and themselves. In the process of opposing payday lending, campaigning organizations discovered that policy advocacy was consistent with other missions, such as providing services to low-income people. These organizations also came to realize the power of coalitions and developed trust in their fellow organizations. Finally, individuals found their voice as active members of their communities and experienced the sense of empowerment that comes with matching beliefs with action. 


\section{Utah's Salt Lake County Leads by Example}

In 1999, the Utah Legislature recognized the rapid growth of payday lenders in the state by passing the Check Cashing Registration Act. The Act covered businesses that cashed a check for a fee as well as those "extending a deferred deposit loan." ${ }^{76}$ The law's requirements were minimal: these businesses had to register with the state, run criminal background check on their managers, and post signs describing their fees and interest rates. A decade later, state law in Utah remained permissive toward payday lenders, but most of Utah's largest cities had used their zoning powers to curb the growth of payday lenders. This section documents the process by which these local ordinances came into being.

\section{Policy Entrepreneurship}

In the summer of 1997, Chris Peterson, a 22-year-old senior at the University of Utah took a job to earn the money for every student's post-college fantasy-a trip around the world. ${ }^{77}$ Peterson worked as a telephone-based debt collector for a company that made payday, car title, and other loans to subprime borrowers. The young man took the job without knowing very much or having an opinion about the payday loan industry. Indeed, the industry was relatively young (although growing rapidly in Utah and nationally) and was subject to little state or local regulation in Utah. ${ }^{78}$ Perhaps the student should have been tipped off when his boss described himself without shame as a "loan shark," but after a few months of calling delinquent borrowers, Peterson could no longer stomach the job. The people on the other end of the phone line would often end up weeping, describing their desperate circumstances but also a pattern by which they paid significantly more than they had borrowed yet couldn't seem to retire their debt. ${ }^{79}$ Peterson saw that his company's loans were making its customers worse off-the opposite of the doctrines he was learning in his economics classes whereby transactions always benefit both parties.

Peterson's discovery about the payday lending industry was being made simultaneously by people-borrowers, activist groups, think tanks, members of the media, government officialsacross the country. But it took until the mid-2000s for some states to restrict or even ban payday lenders. When Peterson enrolled at the University of Utah Law School in the fall of 1998 payday lending was unregulated in Utah and in most other jurisdictions. Peterson made it his personal mission during law school to conduct research on the payday industry and see what could be done to tame these lenders. But during his year off between college and law school, Peterson reached out to political leaders, especially State Senator Ed Mayne, a Democrat who represented the lower-income, west side of Salt Lake County. As the state president of the AFL-CIO, Mayne was respected by his fellow Democrats in the Utah Senate but had little political clout in the Republican-dominated body. In early 1999, the Utah Legislature 
passed the Check Cashing Registration Act. The new law required check cashers and payday ("deferred deposit") lenders to register with the Department of Financial Institutions and required prominent disclosure to loan terms, but the law mandated little else. ${ }^{80}$

While agitating for change at the state level, Peterson also reached out to leaders of his home town of West Valley City, Utah's third largest city at the time and second largest today. As of 2000, West Valley City's population was racially and ethnically diverse compared to the state as a whole, with nearly $20 \%$ of the population being Hispanic and another $7 \%$ being Asian or Pacific Islander. ${ }^{81}$ West Valley City's median household income also was (and remains) lower than the state's average. ${ }^{82}$

Peterson had a major asset in his effort to convince the leaders of West Valley City to address payday lending: his mother, Margaret, was a member of the city council. She was first elected to the council in 1990 and she served continuously until 2007. ${ }^{83}$ With Margaret as his inside champion on the city council, Chris managed to move the idea of regulating payday lenders (and the broader category of check cashers) as far as the West Valley City Planning Commission during the autumn of 1999. The method of reining in payday lenders relied on the power of city zoning: forbidding check cashing businesses to be located within six hundred feet of each other and limiting the number of these businesses to one for every 10,000 residents. The population of West Valley City at the time was about 100,000 , so the long-term ceiling for the number of these businesses would be ten. ${ }^{84}$ (Any excess would be grandfathered in, but no new lenders would be allowed until the number dropped below ten.) The proposal was framed by its backers as a way to overcome the city's image as a lower-income area and thereby boost economic development.

When holding a hearing on the proposed ordinance on November 18,1999 , city planners encountered more and stronger opposition than they expected from the check cashing industry. Its trade association, the Utah Consumer Lending Association, had hired a powerful lobbying firm, Foxley, Pignanelli, Lyon \& Evans. ${ }^{85}$ Frank Pignanelli, a Democrat and the party's former minority leader in the Utah House of Representatives, and Nancy Lyon, a former Republican member of the House, were both on hand at the hearing. ${ }^{86}$ One argument that was used against the ordinance was that it unfairly singled out one type of business, leaving similar ones such as pawn shops and rent-to-own companies, unrestricted. ${ }^{87}$ By the end of the evening, the city manager and the assistant city attorney realized that they needed to go back to the drawing board.

Chris Peterson responded to the 1999 defeat of the West Valley City proposal by redoubling his efforts to achieve reform at the state level. He did so using empirical research and legal analysis. In this respect, Peterson was functioning in the classic mode of a "policy entrepreneur," dedicated individuals who find or create opportunities to advance their policy 
objectives. ${ }^{88}$ He was attempting to generate and disseminate information as a means of transforming his personal awareness of the problems associated with payday lending into an issue on the agenda of policy makers (primarily, state-level ones).

In 2001, he published the first of two articles. The article appeared in the Utah Law Review and was built around three objectives: (1) document a problem, (2) explain why market forces alone would not solve it, and (3) recommend policy responses. ${ }^{89}$

The 2001 article took aim at the impact of multiple types of high-cost credit, but payday lenders (what Peterson called "post-dated-check lenders") received the most attention. Peterson reported the results of two empirical studies of the Utah high-cost credit market. First, drawing on research by Professor John Carsky, Peterson used classified listings in Yellow Pages to document the dramatic growth of pawn shops and check cashing services in the Salt Lake area between 1980 and 2000. With respect to check cashers, the number of company listings (which underestimates the number of outlets when one company has more than one outlet) grew from zero to seventy-five over the two decades.

The second study described in the article attempted to measure the typical interest rates being charged on payday loans. Posing as a potential borrower with a good risk profile (i.e., paycheck stubs spanning the four previous months and a checking account that had been open for seven years), Peterson obtained loan quotes from twenty-six lenders, or roughly a third of all payday loan companies. When expressed on an annual percentage rate basis, the loans ranged in cost from $360 \%$ to $780 \%$. The modal rate was $520 \%$, and the average was $528 \%$. Peterson attempted to shock the reader by stating: "By way of comparison, the average reported interest rates for extortionate criminal loan shark syndicates in New York City during the 1960s were relatively inexpensive at $250 \% . " 90$

Next, Peterson drew on his undergraduate training in economics to lay out a theoretically sophisticated explanation of why market forces, by themselves, would not serve the credit interests of low-income consumers. As a result, he argued, a variety of public policy interventions were justified. Addressing state-level policy makers in the legislative, executive, and judicial branches of government, Peterson offered a variety of proposals. They included: capping delinquent payment fees on loans with interest rates exceeding $40 \%$; requiring dramatic, "red flag" warnings, similar to those on cigarette packages, affixed to contracts; providing a clear legislative definition of what constitutes an "unconscionable" loan; encouraging more aggressive enforcement of the Check Cashing Registration Act's disclosure provisions by small claims courts; and reducing barriers for debtors to appears in these courts. 
The second article, published in the March issue of the Utah Bar Journal, was more narrowly focused on deferred deposit loans. ${ }^{91}$ It covered essentially the same ground as the earlier article in terms of its empirical analysis and policy recommendations, but the second article was far briefer and presented in a manner that would appeal to readers outside the legal community.

Peterson's two articles focused exclusively on the options for state regulation of payday lenders; there was no mention of the possibility of action by cities or counties. It is therefore a bit surprising that by September, 2012, he and especially his mother would have engineered passage of Utah's first law using local zoning to curtail payday lending.

\section{West Valley City's Ordinance}

The efforts of West Valley City to control the growth of payday lenders within its boundaries unfolded into two stages in 2002. First, in May, the City Council approved the addition of several use limitations within the city's overlay zones. (Overlay zones are subject to requirements or restrictions over and above those in the "underlying" zone.) The city had three overlay zones. In two of these, the city manager John Patterson suggested, bail bonds, pawn shops, check cashing, payday loans, car title loans, tattoo establishments, and sexually oriented businesses would be added as uses not permitted. In the third zone (a business park along a state highway), the limitations would apply only to bail bonds and payday loans. ${ }^{92}$ Patterson argued that the three areas were gateways to their city, and the listed businesses were not compatible with the image of itself that the city wished to convey. ${ }^{93}$ Despite prior announcement of the opportunity to comment on the proposal, no one was present to speak either in favor or in opposition to the motion. Accordingly, the City Council voted unanimously (with one abstention) in favor of the zoning change.

The city's new restrictions lumped together payday lenders with a variety of other types of businesses that cities often view as harmful to their image and economic development. Two months later, Joseph Moore, the community economic development director, presented to the city Planning Commission an ordinance that would provide an additional level of review and approval for check cashing businesses (under which rubric "deferred deposit loans" were included).

The proposed ordinance was drafted by city attorney Nicole Cottle at the direction of the city council. Leaning on ordinances elsewhere that restricted other controversial land uses such as 7-Eleven stores open twenty-four hours a day and sexually-oriented businesses, Cottle's ordinance included a formula that would allow only one check cashing business for every 10,000 citizens of the city-a standard that was already saturated by existing check cashing businesses. In addition, there would be a mandatory separation by 600 feet of check cashing 
businesses from other residential or commercial uses and a separation of 600 feet between check cashing businesses. ${ }^{94}$ There was no one present who wished to comment on the proposal-a sharp contrast with the Planning Commission's meeting in 1999 when the payday industry was represented by two former state legislators and managed to derail the proposed regulations. This time, the motion passed unanimously and was forwarded to the City Council.

When the City Council considered the proposed ordinance, the only major change was the addition of car title lenders as businesses subject to the density and distance restrictions. As with the meeting of the Planning Commission, no one was present to speak for or against the ordinance. After discussion, the City Council approved the ordinance unanimously, with all members of the Council present and voting. ${ }^{95}$

The placid proceedings belied a more complex story of obstacles to be overcome. First, there was the memory of the unceremonious defeat of a similar proposal in November, 1999. City attorney Nicole Cottle was only a few months out of law school at the University of Wyoming and in her first few weeks on the job. The experience left the message that passage of an ordinance would not only require fending off a powerful industry while a proposal was being debated but also the possibility of a lawsuit should an ordinance be enacted.

Second, city council member Peterson and city attorney Cottle were aware that West Valley City's citizens lean toward the conservative side of the political spectrum, and both city leaders were eager to preserve the image of their city as business-friendly. Hence, they knew that they would have to frame their payday ordinance in terms of the city's economic development, not the morality of payday lending.

A final obstacle rested within the West Valley City Council itself. One of the council members had a commercial interest in a payday lender. This conflict of interest could be difficult to overcome.

The main method by which Peterson and Cottle addressed these obstacles was by drawing a distinction between the "secondary effects" of payday lending and its "social effects." The secondary effects, which included crime, calls for police service, and reduced property values, formed the basis of their justification for the ordinance and were documented with data. The social effects, which referred to the suffering of people who took out high-cost payday loans but ended up in a cycle of debt, lawsuits, and wage garnishment, were largely off limits.

The decision to emphasize the secondary effects of high-cost lending fit well with Cottle's perspective and proclivities. She perceived West Valley City as being at a tipping point. She said: "We're either going to slide off the edge of this cliff and become a poverty-ridden, crimeridden, dilapidated, blighted community, or we're not." ${ }^{\prime 96}$ Cottle also liked the fact that secondary effects could be measured and quantified, something that would make the 
ordinance more legally defensible. And she liked the fact that the approach didn't have a hint of paternalism, that is, the need to restrict payday loans because borrowers are not smart enough to avoid them. Cottle distinguished her city's ordinance from efforts in cities such as New York and San Francisco to tell people how big their soda cup could be or the type of fat in which their restaurant food could be fried. She viewed these examples of managing the consumer as out of step with the philosophy of her city and state." ${ }^{\prime 97}$

The decision to steer clear of the social impact of payday loans pained Councilwoman Peterson. She had heard her son Chris's stories about payday loans tormenting single mothers, and she was a single mom herself at that time. ${ }^{98}$ She also reported having a friend and co-worker who were caught up in it. ${ }^{99}$ Peterson had become convinced that high-cost lending was destructive, but she did not feel the need for her fellow council members to agree with her as long as they voted for the ordinance.

The ordinance supporters also benefited from far less resistance from the lending industry than they had expected. Cottle recalls that initially we had a lot of cursory resistance but then the industry got smart. The big players in the industry said to themselves: "This might not be such a bad thing for us because we already are here. The ordinance could potentially limit competition." 100 Cottle didn't worry about the lack of competition because there were already many lenders, but she was thankful if this perception on the part of the industry reduced kickback to the ordinance.

There were sixteen payday lenders in West Valley City in 2002 when the ordinance was enacted. As Cottle described the situation, "You could get to a payday lending institution within five minutes from wherever you were in the city." ${ }^{101}$ As of 2016, there were twelve lenders, a few of the smaller, less successful ones having packed up when their lease ran out. Neither Peterson nor Cottle are confident that the West Valley City ordinance reduced the number of high-cost loans taken out by their citizens, but Cottle feels that the ordinance forestalled a nightmare scenario of "forty or fifty of those businesses in our city at the rate they were going and at the rate they exist in unregulated areas." ${ }^{102}$

\section{The Ripple Effect in Metropolitan Salt Lake City}

West Valley City is located near the center of Salt Lake County. It borders Salt Lake City, the largest city in the state, but also three other cities of moderate size: South Salt Lake City, West Jordan, and Taylorsville. (See Figure 1) 


\section{Figure 1: Cities in Salt Lake County, Utah}

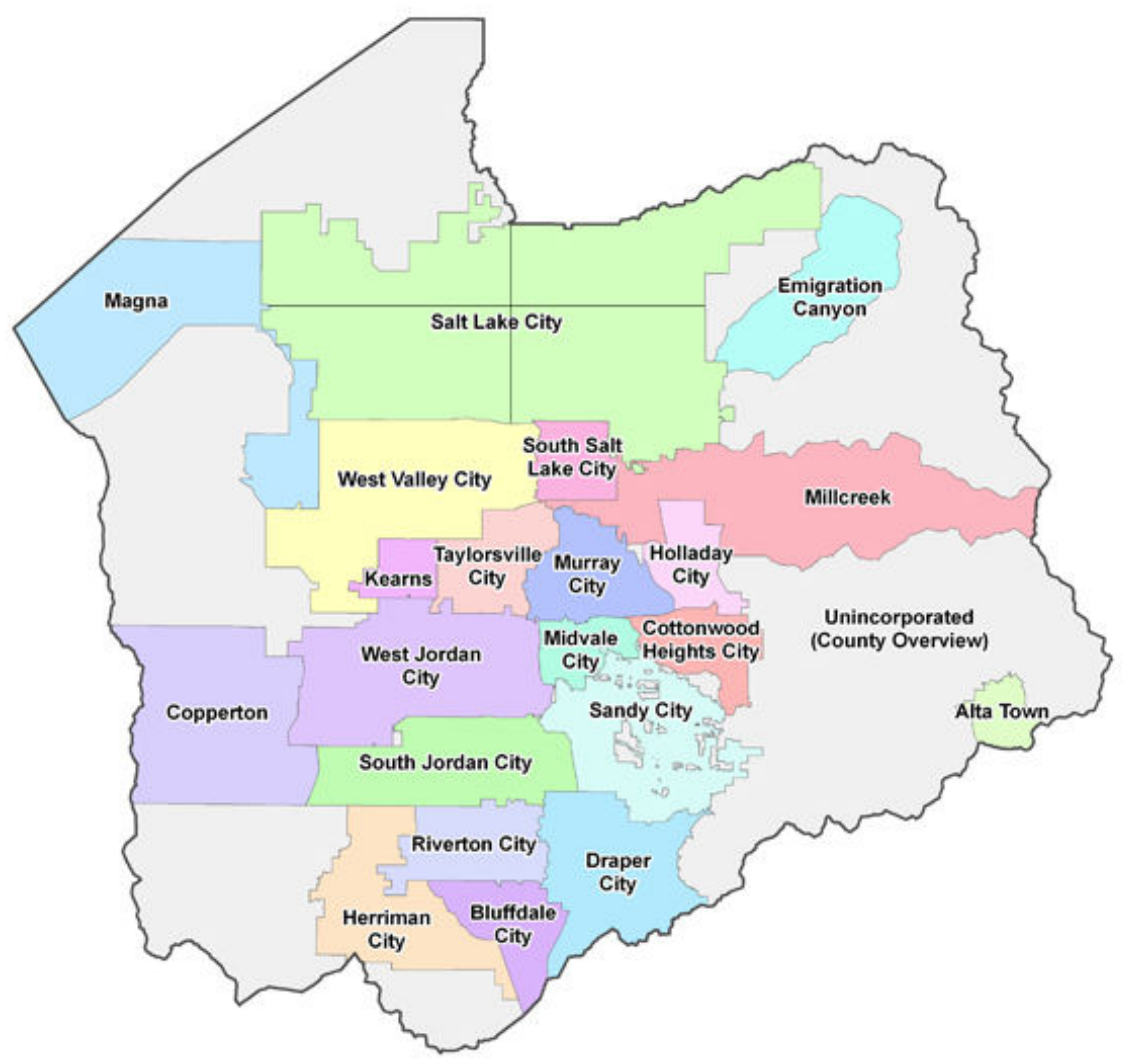

Source: Salt Lake County Cooperative Plan, http://gis.rbf.com/slco/.

When Margaret Peterson and Cottle were working toward passage of their payday ordinance, they reached out to their counterparts in neighboring cities for support but received none.

Cottle recalls calling around to the cities surrounding West Valley City and asking whether they, too, were seeing an influx of payday and other high-cost lenders. Cottle recalls the responses: "We don't have that problem." The leaders of adjacent cities wanted to believe, according to Cottle, that the surge in high-cost lending was unique to the demographic profile of West Valley City's residents-low-income, minority, and immigrant. But Peterson said that leaders in these cities just needed to open their eyes, saying: "I could see it. Everybody else could see it." 103

By the end of 2004, the eyes of the city leaders in adjoining cities were open. West Jordan, the largest of these cities, moved most swiftly. In February, 2003, its planning commission proposed an ordinance explicitly modeled on West Valley City's in terms of requiring a thousand foot separation between payday lenders ("check cashing credit services") and setting an overall cap on their numbers at one per 10,000 citizens. With a population of nearly 100,000 , this equated to ten payday lenders. ${ }^{104}$ 
The West Jordan City Council discussed an ordinance on March 25, 2003. In the debate over the ordinance, supporters cited the precedent of using zoning to regulate the number of sexually-oriented businesses in the city. One concern was that, with a population of nearly 100,000 , the city already had two more than the permitted ten payday lenders, but the city's director of community and economic development, Tom Burdett, assured the council that the number of lenders would eventually come into conformity as their numbers declined or the city's population increased. There were twelve such lenders at the time the ordinance was passed, so the expectation was that, with attrition, the number of lenders per capita would drop to ten. The only real point of contention was whether payday lenders had been given adequate notice of the proposed change. Councilmember Stuart Richardson, who admitted that he had a conflict of interest because he leased a building to a payday lender, proposed postponing a vote until after giving local payday lenders more time to comment on the ordinance, but he was outvoted. The ordinance then passed unanimously, including an affirmative vote from Richardson. ${ }^{105}$ (Unlike West Valley City, the ordinance also covered pawnshops and bail bondsmen.)

The next domino to fall was the city of Taylorsville. At the November 9, 2004 meeting of its planning commission, Mark McGrath, director of community development for the city, presented a proposal to define check cashing as including deferred deposit loans and setting the same distance and density restriction as those in West Valley City. No members of the public spoke on the subject, and the motion passed unanimously.

The proposal was more controversial when discussed a month later at the Taylorsville City Council. Don Adams, the city's director of economic development, urged the city councilmembers to adopt the new zoning rules, and Mayor Janice Augur supported the idea as well. She cited the spillover effect of neighboring cities limiting the number of check cashing establishments. One member of the council, Morris Pratt, removed himself from the discussion, citing his economic interest in a deferred deposit lending institution. Councilman Russ Wall spoke in favor of the ordinance. He obliquely attributed the rise of payday lenders in Taylorsville to caps on these lenders in surrounding cities. That aside, he argued the burden created by an inordinate amount of police service in the areas where payday lenders are located. Wall also indicated that these businesses have a stigma associated with them that inhibits more desirable businesses from locating within Taylorsville. ${ }^{106}$

Then discussion turned unfavorable. ${ }^{107}$ Council member Bud Caitlin recommended that a moratorium be put in place so that the city could further study the matter. A local business owner felt that limiting the number of check cashing businesses would have monopolistic consequences. An employee of the city newspaper, The Eagle Sentinel, objected to the precedent being set in limiting the number of businesses. Once the brief public hearing was 
closed, councilmember Pratt, who earlier said he would refrain from the discussion, stated that check cashers provide a service that fills a need, and he argued that state regulations already serve to eliminate bad practices. Councilman Russ Wall expressed his concern that the ordinance might end up in litigation. Ultimately, the motion failed on a 3-2 vote, with Pratt ignoring his conflict of interest and voting no.

By July, 2005, the position of the council had reversed itself as the city council voted in favor of the same ordinance they had earlier rejected. This time, Pratt chose not to vote, and even in the absence of councilmember Jerry Rechtenbach, who had earlier voted for the ordinance, it passed $3-0 .{ }^{108}$ The rising number of lenders probably played an important role. There were seventeen check cashing establishments at that point for a population of 60,000 residents. Thus, the limit of one establishment per 10,000 people was largely symbolic since existing lenders were exempt.

In November, 2005, the Deseret News, the more conservative of Utah's daily newspapers, published a three-part series on payday lending by Lee Davidson. ${ }^{109}$ The series was not complimentary. It described borrowers caught in a "vicious cycle" of debt. The articles frequently quoted lobbyist Frank Pignanelli in defense of the industry and Chris Peterson as its critic. An additional opponent of payday lending was also cited in each article-Linda Hilton of the Coalition of Religious Communities (CORC), an alliance of about fifteen faith-based organizations dedicated to fighting poverty in Utah. CORC was founded in 1995 and paid attention to payday lending starting in 2000 , but it devotes its limited resources primarily at the state legislature. ${ }^{110}$ In one of the articles, Hilton cited the "border effect": once West Valley City adopted its ordinance, "new lenders started popping up just over the border in Taylorsville, often literally across the street from West Valley City."

The border effect was in full force. By the end of 2007, virtually all of the cities plus the unincorporated portion of Salt Lake County were covered by either moratorium on new payday lenders or an ordinance similar to that of West Valley City that capped their number. ${ }^{112}$ The one glaring exception was Salt Lake City, the largest city in the county, but city leaders passed a West Valley City-style ordinance in 2009. ${ }^{113}$ During the process of passing these ordinances, Linda Hilton and CORC increasingly became the face of opposition to payday loans in Utah.

\section{Interest Group Pressure in Utah}

Hilton was an employee of Crossroads Urban Center, a non-profit organization affiliated with the United Methodist Women that assists, organizes, and advocates for low-income, disabled, and minority members of the Utah community. Crossroads is Utah's busiest emergency food pantry and is well known in the Salt Lake community for its Thanksgiving and Christmas food 
giveaways, allowing thousands of families to enjoy a complete holiday dinner with turkey and all the trimmings. ${ }^{114}$

Hilton's contact with clients at Crossroads served as her education about check cashers and payday lenders. As she told us:

At Crossroads, we require some sort of photo identification to get services. I was in the pantry one day doing intake when a lady presents herself with a Check City Check Cashing Privilege card with her picture on it. I said, "What kind of ID is this," and she said, "I use it to cash my monthly disability checks and my mother's Social Security checks. They normally charge us twenty dollars per check, but I bought this card from them for twenty dollars, so now I can cash each check for ten dollars, so it's a discount card." Hilton thought to herself, "It's outrageous to pay that much to cash governmentguaranteed checks. And those check-cashing charges just took away money to afford meat or the electric bill."115

Hilton also learned from clients how clients paid their electric bills when they did not have the funds to cover them. More and more people were coming in to Crossroads saying, "I'm in the debt trap with a payday lender. I took out this loan to help pay the electric bill, and now I'm here and I need help paying the next electric bill and getting out of this payday loan." 116 So all of these experiences created what Hilton called "the perfect storm" in terms of making Linda aware of high-cost financial services. She asked herself, "Has anybody done anything on this? What do we do? Where do we start? There ought to be a law." Some of her questions were answered when she came across Chris Peterson's 2002 article in Utah Bar Journal. Like Peterson, Hilton's first thought was that the state of Utah ought to be reining in check cashers and payday lenders. Thus began more than a decade of lobbying by Hilton and CORC to tighten the rules governing payday lending in Utah. At CORC's 2002 annual meeting, regulating the payday loan industry emerged as one of the organization's three top issues. ${ }^{117}$ In 2003 , Hilton and her CORC allies helped place the first of several incremental controls placed on payday lenders by the state legislature, but the goal of an interest rate cap has eluded CORC so far. ${ }^{118}$

The fight to enact zoning ordinances in Utah's cities came to Hilton and CORC, rather than the other way around. She was contacted by a member of the Taylorsville city council in 2004 about the creeping of payday lenders across Redwood Road from the West Valley side to the Taylorsville side. She offered to "send out a team from our coalition" to take the West Valley City ordinance and "cross out West Valley and put in Taylorsville." ${ }^{119}$ Hilton also recalls meetings with members of the Taylorsville city council to educate them and seek their votes: "One person was hopeless but we talked to the people who were probable votes and possible votes." ${ }^{120}$ CORC's members were religious organizations, so when possible, she brought to these meetings a pastor or other religious leader from a church in the district. 
In their meetings with decision makers in Taylorsville and other cities, CORC had three main talking points. First, your constituents are paying more than $500 \%$ interest on these loans, and CORC brought along contracts as proof. Second, money spent on exorbitant interest rates forces people to rely more heavily on the city's emergency services, fall behind on their rent, and, in the case of property owners, be delinquent on their property taxes. Third, most payday lenders are headquartered outside of Utah, so their profits are leaving the state.

CORC encountered several counterarguments from city leaders. One was that "you can't regulate stupid." ${ }^{121}$ Hilton's response was to ask dubious councilmembers whether they had carefully read the contract for their credit card or mortgage. If not, then perhaps the line between smart and stupid is not so sharp. Pushback against a proposed ordinance also took the form of faith that the free market and competition would eventually drive down interest rates. This argument was purely theoretical to Hilton compared to the borrowers she met who were in crisis mode because their payday loan obligations alone exceeded their income.

To Hilton, the meetings with individual city council members are crucial. She said:

One lesson that I would have for anybody who's trying to do this work is pick them off one by one. To go and testify at a council meeting is great to have it on record what payday loans are and how evil they are. But where you really win the votes is meeting with them one on one. We had many, many questions over the years from city council people, county council people, concerning things they had heard about payday lending or information that they needed, like the density of payday lenders they have right now ... Figure out what each person's hot button is, and then address that issue with as much information and detail and data as you can. ${ }^{122}$

Just as the West Valley ordinance stimulated the one in Taylorsville, the Taylorsville ordinance stimulated the appetite of CORC's members for additional ordinances. Hilton said:

Once Taylorsville happened, there were other people in the coalition who said, "I live in city $X$ in suburban Salt Lake County, and these lenders are popping up all around us too. I know a city council person or I know the mayor's sister, or whoever. So we should do something there." We started dividing up the Valley and seeing where the most feasible areas were and started picking them off with the goal of locking up the entire county. ${ }^{123}$

Passing ordinances was easier in some cities than others. Hilton cited Mayor JoAnn Seghini as especially supportive and her city council as fairly progressive. Midvale also has a large percentage of racial minorities and renters, making it both an attractive place for payday lenders and a good place to see the negative effects of these loans. Representing CORC at the August, 2006 city council meeting was Arthur Sutherland, a recent retiree who had moved to Utah after a career as an aerospace engineer. ${ }^{124}$ Wanting to do something worthwhile, he 
spoke to his pastor, who directed him to Linda Hilton at CORC. At the Midvale City Council, Sutherland was the only one to speak about the ordinance, which passed unanimously. ${ }^{125}$

More affluent and more Caucasian Sandy, Utah, was a heavier lift for Sutherland. In front of the Sandy City Council, Sutherland faced off against John Swallow, the general counsel for the payday lending company, Check City. The statuesque Swallow was forty-four years old at the time. He had represented Sandy in the Utah House of Representatives for six years, was the unsuccessful Republican candidate for the U.S. House of Representatives in 2002 and 2004, and was elected Utah Attorney General in 2012. ${ }^{126}$ (He resigned in 2013 and currently faces federal corruption charges related, in small part, to his relationship with the payday lending industry.) $)^{127}$

Like previous ordinances passed in Utah, the Sandy proposal capped payday lenders at one per 10,000 residents. This left room for only one more store in Sandy despite there being four applicants. Check City was one of those applicants, and Swallow wanted the winner to be his company. He and two other employees of Check City addressed the city council on February 21,2007 , citing the value of payday loans for people facing financial emergencies. Sutherland, a resident of Sandy, countered that payday lenders trap and then harass people in desperate financial straits. At the end of the evening, the council voted to postpone consideration of the ordinance. $^{128}$ During the next few weeks, Swallow managed to secure the last slot for Check City, and on March 7, 2007 the ordinance passed by a narrow 4-3 vote. ${ }^{129}$

Sometimes supporters of payday ordinances get lucky . . . and a good laugh. One such instance took place at a meeting of the Salt Lake County Council. Councilmember Joe Hatch was the inside champion for a measure that would cap the number of lenders, and he waged a two-year campaign culminating in a 2008 ordinance. ${ }^{130}$ Hilton, Sutherland, and several other members attended a meeting of the council in 2007. Upon arriving, they were surprised to find the council room packed despite it being $2 \mathrm{pm}$ on a Wednesday afternoon. As Hilton tells the story, the payday lenders had paid a large number of Hispanic people to attend wearing yellow tshirts saying "Love Payday Lending." Hilton had an opportunity to testify as did payday representatives. One of these speakers argued that passing an ordinance would take away access to credit. He then turned to the people in the room and asked, "Would everybody that wants to keep payday lending and is against the ordinance please stand up?" Nobody budged. Then a lady said something in Spanish. The people in the t-shirts start looking at each other and then many of them stood up. Councilmember Hatch tried hard to smother his laughter and maintain decorum because it was so ridiculous to him. ${ }^{131}$

\section{Impact of the Ordinances in Greater Salt Lake City}

A timeline of payday ordinances in Salt Lake County is presented below. 


\title{
Salt Lake County Ordinance Timeline
}

\author{
2009: Salt Lake City
}

2007: Murray, Sandy, Unincorporated Salt Lake County

2006: Draper, Midvale

2005: Taylorsville

2003: South Jordan, West Jordan

2002: West Valley City

1999: South Salt Lake City

To date, no rigorous evaluation study has been conducted to estimate the impact of the eleven local ordinances that were passed in Salt Lake County between 1999 and $2012 .{ }^{132}$ At a minimum, this type of study would measure changes in the availability of payday loans as measured by the number of outlets. (Ideally, one would want to track the number of loans received and the interest rates charged on them, but this is difficult for a number of reasons, including the growth of internet-based payday lending.) In late 2008, an article in one of the state's two leading newspapers, the Deseret News, noted that the rapid growth of payday stores in the state had slowed markedly compared to the 1995-2005 period. ${ }^{133}$ Nevertheless, the article noted there were more stores in the state than the number of 7-Elevens, McDonalds, Burger Kings and Wendy's-combined.

City leaders whom we interviewed in West Valley City and Midvale provided specific examples of payday lenders that had closed yet could not be replaced because the number of outlets per capita exceeded the number permitted. Existing excess outlets had been "grandfathered" under the ordinances, but new outlets could only be approved if the number of stores fell 
below the per capita maximum. In West Valley City, the number of lenders had dropped from sixteen to twelve in the post-ordinance period. ${ }^{134}$ Population growth since 2002 would have allowed a thirteenth lender, but no applicants had stepped forward. ${ }^{135}$

Despite a modest decline in the number of outlets in some jurisdictions with density and distance ordinances, Wendy Gibson, speaking for the Utah Consumer Lending Association, argued that any reduction in the number of new stores was due to the maturation of the industry and the saturation of markets. Gibson did not believe the ordinances had any effect on loan availability. Phillip Hill, assistant city manager for community development in Midvale, tended to agree with Gibson. He noted that there had been about a dozen lenders when the city of 30,000 people passed its ordinance in $2006 .{ }^{136}$ As of mid-2005, there had been a drop to about eight or nine payday lenders, according to Hill, largely because there had been too many lenders for the original population base. Even though Midvale's population is now approaching 40,000 , it will be a long time before a new payday outlet can be approved because of the per capita limit, but he saw no signs that people who wanted payday loans cannot obtain them.

Even the activists who worked for the passage of the ordinances held very tempered views of the impact of the ordinances. Arthur Sutherland observed, "There are enough [payday lenders] out there if you are willing to go a little distance. It may be a little hard to shop around because you are going to need a car instead of being able to walk from one store to another. But there are enough of them out there for borrowers to take out a loan from one guy to pay off the loan from another guy and pretty soon have to take out a loan from another guy to pay that off."137

The gloomiest assessment of the Utah ordinance "movement" came, surprisingly, from Chris Peterson, the person who did so much to expose the payday loan market in Utah and convince his mother to tackle the industry in West Valley City. After passage of the West Valley City ordinance in 2002, Peterson worked for a year in Washington, DC as an attorney for the consumer activist group, United States Public Interest Research Group. In 2003, he began a four-year stint as an assistant and then associate professor of law at the University of Florida, during which time he published a book, Taming the Sharks: Towards a Cure for the High Cost Credit Market, tracing the evolution of high-cost credit markets in the U.S. ${ }^{138}$ In 2007, he returned to the University of Utah Quinney College of Law where he has been a professor ever since. $^{139}$

Recall that Peterson's articles on payday lending in 2001 and 2002 had recommended statelevel regulation of payday lenders. Looking back from the vantage of late 2015, Peterson said:

I never had a great deal of faith in those local ordinances, and since then I've had even less. I never saw those ordinances as very promising, so I honestly didn't invest that much time into it. At the time, I remember telling myself, "Well, let's just get a win, and 
it will help raise the profile of the problem. Maybe it will deter a few locations, and maybe that's good at the margin." But there were already so many lenders out there that it seemed to me that West Valley City was already saturated, and that capping them, or even pulling them back a little bit via attrition was not really going to help people very much. Also, some of the people on the city council were worried about blight, but to me the more concerning issue was what was happening to those borrowers, and this didn't seem like that promising of a method for helping them. . . At the time, though, I felt like the city had very limited options and ought to do something, and this was the best that they could do.

In retrospect, I don't think that that's true. I think there are better things that cities can do than zoning ordinances. But that's only become clear to me now. As more and more cities pass these ordinances, they don't really decrease the volume of lending. They create an illusion of actually having done something when nothing has really been done, and that tends to demobilize political change. So since then, in West Valley, my sense is that back then, there was a real growing movement to actually do something. This was not something that had been done in the state before; it was a new idea, and there was real momentum to actually do something. But then that momentum got spent out going down a false path that didn't really provide meaningful reform for folks. Instead of being a stepping stone to building for a more sustaining and more meaningful change, I think it became a false lead in the maze that became a dead end, in my opinion. ${ }^{140}$

What are those "better things" that Peterson believes that cities can do? In a 2012 article, Peterson recommends that local jurisdictions use their power to regulate merchants' exterior signage. ${ }^{141}$ Specifically, he proposes that lenders offering loans with annual percentage rates exceeding $45 \%$ should be required to display on their street, storefront, and other exterior signs a message designed to give pause to potential customers. The message would be similar to a warning on the labels of cigarettes, alcoholic beverages, or potent prescription drugs. But instead of referring to the dangers of the product, the sign would refer more bluntly to the payday store. It would say, "Warning: Predatory Lender." So far, no city has taken up Peterson's proposal.

Despite the pessimism of Peterson's assessment of density and distance ordinances, the Utah ordinances were precedent-setters. The West Valley ordinance was one of the first in the country to set a limit on the number of lenders per capita and set minimum distances between these lenders. In addition, the Utah ordinances testify to the power of deeply committed individuals - whether an issue champion within government or a policy entrepreneur applying pressure from the outside-to change the rules governing payday lending in their communities. They did so in Utah without funding for research studies, public opinion polls, focus groups, 
advertising campaigns, or coalition-building. The ordinance supporters did benefit, though, from sympathetic press coverage, especially from Lee Davidson of the Deseret News and later the Salt Lake Tribune. According to Linda Hilton, Davidson's coverage helped educate the general public and move individuals to action. She recalled that friends would say to her:

"Oh, I read that article! I had no idea! This is awful! You know, maybe I should get involved. Maybe I should do something." Or, "I had no idea that you were working on this. Let me tell you about my" fill in the blank-niece, brother, son-who's got problems with payday lending. So, his reporting brought us victims through the reporting, which has been really helpful. ${ }^{142}$

Hilton also believes that the local ordinances aided her efforts to get state-level regulation of payday lenders, but she laments that this catalytic effect has been weaker in Utah than in some other states. Her goal, like that of Chris Peterson, Art Sutherland, and a handful of other consumer advocates like Laura Polacheck of AARP Utah, remains strict state-level rules, including an interest rate cap, that would make local ordinances unnecessary. ${ }^{143}$ 


\section{Silicon Valley Earthquake-How Grassroots Advocacy Shook Up Payday Lending}

\section{SVCF Prioritizes Payday Lending}

Silicon Valley Community Foundation (SVCF) was launched in January, 2007, the result of an unprecedented merger between two community foundations - the Community Foundation of Silicon Valley and the Peninsula Community Foundation. Serving the people of San Mateo and Santa Clara counties, SVCF describes itself as "a catalyst and leader for innovative solutions to our region's most challenging problems." 144 Emmett D. Carson, Ph.D., was selected to be the founding CEO and President of SVCF. ${ }^{145}$ With assets that have grown rapidly to almost $\$ 8$ billion, SVCF is the world's largest community foundation. ${ }^{146}$ Community foundations, as public charities, have more latitude in funding advocacy activities and engaging in lobbying themselves than private foundations, and SVCF has exercised these prerogatives. ${ }^{147}$

Shortly after the merger, SVCF conducted a community input project to engage the community and choose priorities of importance to their constituents. Through the project, SVCF conducted research and an on-line survey, and held a series of nine strategic conversations with people in the community, including donors, government officials, leaders of nonprofit organizations, and members of the public at large. ${ }^{148}$ The board of directors and staff at SVCF then held discussions on how their grantmaking activities could make the greatest positive impact on the lives of people in the Silicon Valley area. Based on the initial research and community input process, SVCF's leaders selected four areas of highest priority, one of which was titled "economic security" and encompassed anti-predatory lending advocacy along with assetbuilding and financial education. ${ }^{149}$

SVCF found that in a geographical area known for its prosperity and innovation, there were wide economic disparities. Many community members were already asset-poor, even before the recession brought on by the bursting of the housing bubble in 2008. Now, with even fewer assets, people were vulnerable to financial emergencies, such as those caused by job loss or a health crisis. In the face of these emergencies, high-cost payday loans could seem like the only solution, despite the long-term negative impact on asset-building.

The details of payday lending, once highlighted through the community input process, alarmed the leadership at SVCF, who noted that there was even a payday loan store located one block away from their offices. ${ }^{150}$ The situation called for SVCF's involvement, but there was an impediment to jumping right in to combat payday loan abuses: SVCF's parent foundations did not have traditions of funding (let alone engaging in) public policy advocacy. ${ }^{151}$ This meant that doing policy work would require approval by SVCF's board. CEO and President Emmett Carson 
came from the Minneapolis Foundation, a foundation that did policy work. He felt that SVCF should also fund local organizations that engaged in policy advocacy and, from time to time, take a leadership role on certain issues. ${ }^{152}$ SVCF staff gradually built support among members of the board of directors, and in 2009 the board approved grants for the specific purpose of addressing predatory payday lending.

Before requesting proposals for this work, SVCF leadership-led by Ellen Clear, Vice President for Grantmaking; Erica Wood, Vice President for Community Leadership; and Pat Krackov, Program Officer for Economic Security-articulated their vision in Asset Building and Financial Education: Critical Vehicles for Helping Low-Income Families Achieve Greater Economic Security. The document, authored by Krackov, was used to educate donors and show that payday lending was an issue of deep importance to people from many diverse parts of the Silicon Valley community. The report argued for a combination of financial education and asset building as the long-term foundation for economic security. In particular, the research paper stressed the need to:

- Combat predatory lending practices that siphon money away from families;

- Increase access to affordable financial services that help families develop credit histories and other key banking relationships; and

- Create incentives so that families can more easily save and build wealth. ${ }^{153}$

The research paper identified two goals for SVCF's grantmaking: (1) "to increase the availability of financial education, counseling and legal services, as well as asset building products, by scaling effective programs and services or designing and piloting new ones" and (2) to "promote policy advocacy that supports an asset-building agenda focused on anti-predatory lending measures to effect change at the municipal and state levels and to generate public awareness about the topic." ${ }^{154}$

While not focusing exclusively on payday lending, the research paper described payday lending as one piece of a much larger problem that could be addressed through organized advocacy efforts. The research paper cited the use of moratoria and zoning ordinances in cities such as Oakland and San Francisco to curb the number of payday lending establishments in their communities. It noted as well that non-English speaking families could greatly benefit from SVCF's advocacy work, as could local youth, who could in turn educate their families.

Finally, the research paper made the case for the appropriateness of financial education and asset building as activities for SVCF. The report argued that these efforts fit squarely within SVCF's vision and mission of inspiring civic participation to address the most challenging problems in San Mateo and Santa Clara counties. ${ }^{155}$ The proposed activities were presented as building upon the past community development initiatives of the Peninsula Community 
Foundation, SVCF's own efforts to bring a credit union to East Palo Alto, and the expertise of SVCF's staff.

The grantmaking strategy paper constituted a roadmap for SVCF's efforts. Internally, it was designed to generate buy-in from the members of SVCF's board of directors. Externally, it signaled to potential grantees SVCF's goals with respect to asset building and its preferred strategies. With respect to payday lending, SVCF expressed the view that a cap on interest rates on the order of $36 \%$ is generally recognized, locally and nationally, as "the most effective

regulatory lever for reducing" predatory lending practices. ${ }^{156}$ In addition to acknowledging the importance of a state-level interest rate cap, SVCF articulated its support for locally-based efforts to enact anti-payday lending ordinances throughout Silicon Valley.

\section{SVCF Commissions a Report on the Status of Payday Lending in California}

Before issuing its first request for proposals (RFP) for Anti-Payday Lending Policy Advocacy in June, 2009, SVCF commissioned a study to help guide this work. ${ }^{157}$ The study, Report on the Status of Payday Lending in California, was conducted by the Public Interest Law Firm (PILF) of the Law Foundation of Silicon Valley and issued in October 2009. According to a foreword to the report by SVCF's CEO and President, Emmett Carson, the study's findings dramatically revealed how payday lending traps many low-income borrowers-especially those in AfricanAmerican and Latino communities--in deepening cycles of debt.

The study also offered possible policy work at the federal, state and local levels. Describing federal and state action to date as inadequate, the report included a section on what would become a major thrust for SVCF's future work in this space: the passage of local municipal and county zoning ordinances to restrict payday lending. Like SVCF's research paper authored by Krackov, the authors cited approving recent payday ordinances in Oakland, San Francisco and Sacramento, and encouraged advocates in other large cities, including San Jose, to mount campaigns for similar ordinances. ${ }^{158}$

In June, 2009, several months before the PILF study was released, SVCF released its RFP to promote Anti-Payday Lending Policy Advocacy. ${ }^{159}$ The RFP laid out SVCF's two-part strategy for curbing payday lending: first local ordinances to ban or restrict new payday lending establishments, and, eventually, a statewide payday loan interest rate cap. The call for proposals encouraged applicants to prepare themselves to meaningfully participate in efforts to pass local ordinances by studying the experiences of cities such as Sacramento, Oakland and San Francisco as well as others around the country. 


\section{Prior Action in Major California Cities}

Prior to 2009, Oakland and San Francisco, the other two large cities in the San Francisco Bay Area, had enacted local ordinances to restrict payday lenders. On October 10, 2004, the Oakland City Council gave final approval to an ordinance that required any new payday lenders (called "check cashiers" in the ordinance) be subject to a conditional use permitting process and meet certain distance requirements. Specifically, check cashiers (or any business engaged in check cashing activity) had to be at least one thousand feet from the nearest check cashier and a minimum of five hundred feet from state or federally chartered banks, community assembly facilities such as recreational centers, and alcohol stores. The ordinance further required that store windows and doors permit law enforcement personnel to have a clear view from the public sidewalk of the entire public area of the premises. Check cashiers also had to post at least one no-loitering sign (with letters at least two inches tall) in front of their building. Finally, the ordinance limited hours of operation to between 7 a.m. and 7 p.m., Monday through Saturday. ${ }^{160}$

Two years later, on January 10, 2006, San Francisco's board of supervisors issued a 45-day moratorium on the opening of any additional "fringe financial services" to allow the city time to study the impact of payday lending on the city's residents and businesses. ${ }^{161}$ A permanent ordinance was passed in November 2007 that set a "Fringe Financial Service Restricted Use District" composed of several noncontiguous areas in which payday lenders were already numerous. Additional new payday lenders were banned from these areas. Outside of the restricted use district, no new fringe financial service provider was allowed within a quarter mile of an existing provider. As justification, the ordinance cited the potential of fringe financial service to displace other financial service providers offering a broader range of financial services as well as other desired commercial developments. ${ }^{162}$

Completing the landscape of payday lending ordinances in California's largest cities as of June 2009 (when SVCF issued its first RFP with respect to payday lending) was Sacramento, which passed an ordinance three months earlier in March. The Sacramento restrictions closely resembled those implemented in Oakland five years earlier: additional payday lenders needed to obtain a special use permit, maintain a minimum distance of a thousand feet from any other payday lender (as well as any school, religious institution or mainstream financial institution), and be no closer than five hundred feet from any residential zone or other residential use. ${ }^{163}$ In its June 2009 Anti-Payday Lending Policy Advocacy Request for Proposals, SVCF cited the efforts of Sacramento, San Francisco, and Oakland, but if San Jose could be added to the list, it would be the largest California city to date to use its zoning powers to limit payday lending. 


\section{The Role of the California Reinvestment Coalition}

In Oakland and San Francisco, the primary impetus for passage of these protective ordinances came from within city government. In San Francisco, for example, Supervisor Tom Ammiano and Treasurer Jose Cisneros provided the inside leadership to first enact a moratorium and then an ordinance. ${ }^{164}$ In Sacramento, however, the California Reinvestment Coalition (CRC) culminated a multi-year push for payday lending reform by helping to secure passage of an ordinance through persistent education of elected officials and mobilization of community groups and the public.

CRC is a statewide network of organizations that advocate for equitable access to credit for all California communities and individuals. CRC's focus on this work began in March 2005, when its Executive Director Alan Fisher authored its first study on payday lending in California. Titled The Financial Divide, the report criticized the concentration of check cashers and payday lenders in lower-income neighborhoods. ${ }^{165}$ Fisher blamed mainstream financial institutions, especially banks, for closing branches in lower-income communities while helping to finance (and profit from) high-cost providers of credit. He called it "two faces of a seamless financial web. ${ }^{\prime 166}$ Among several recommendations for addressing the harms of a two-tiered system of consumer credit, the report encouraged cities and counties to "restrict the proliferation of predatory lenders through zoning restrictions and other land use tools." ${ }^{167}$

In March 2007, CRC turned up the heat on payday lending by issuing a scathing report titled, Payday Lenders Evade Regulations: A Summary of Findings from Surveying Payday Lending Establishments. ${ }^{168}$ The report provides the results of an in-store survey of 253 payday lending outlets throughout California. The researchers investigated the degree of compliance by lenders with state requirements, especially those dealing with information disclosure to clients. The researchers found that $32 \%$ of payday lenders did not post a complete schedule of fees and an even a higher percentage did not provide accurate estimates of the loan's annual interest rate, both state requirements. Similarly, only $16 \%$ of lenders complied with the requirement to tell borrowers that lenders cannot accept collateral for the loan, and a few lenders unlawfully asked for auto titles as a condition for securing a payday loan. The researchers found that, in addition to failing to comply with state laws, lenders did not even comply with their own industry's self-regulatory standards. For example, the Community Financial Services Association of America requests its members to extend a free, 24-hour opportunity to return the original amount of the loan, yet $38 \%$ of the lenders surveyed did not offer this right of rescission. The report did not contain any policy recommendations, but the implication was that the state needed to beef up enforcement of existing laws. Local zoning designed to curb payday lending was not part of the report. 
As of 2009 when SVCF took up the issue of payday lending, CRC's payday loan activism had been primarily focused on the state level. In 2007, the Center for Responsible Lending (CRL), a North Carolina-based organization with an extensive track record of advocacy, opened a California office in Oakland. CRL's attention was more focused on state-level reforms of payday lending, especially a tough interest rate cap, than on local zoning ordinances. ${ }^{169} \mathrm{CRL}$ 's position was that a payday loan was a debt trap and a $36 \%$ rate cap was the only way to spring it.

\section{Silicon Valley Payday Reform Activity}

\section{The Pacifica Campaign}

The opening rounds in the fight to restrict payday lenders in Silicon Valley took place in Pacifica and East Palo Alto, both in San Mateo County. Two SVCF grantees provided pressure from outside on the City Council to pass a short-term moratorium with a longer-term goal of preventing any additional payday lenders from locating in Pacifica. The two SVCF grantee organizations were the Insight Center for Community Economic Development and the Pacifica Resource Center (PRC), while Councilmember Mary Ann Nihart provided the necessary leadership within the council. ${ }^{170}$

Even though Pacifica had only three payday establishments, it had the largest number of lenders per capita than any other city because of its small population size. Anita Rees, Executive Director at PRC was well positioned to address the human toll of payday lending because PRC was a well-established charitable organization devoted to helping Pacifica families and individuals meet their food, housing, and other basic needs.

In October, 2010, the Insight Center and PRC presented data to the Pacifica City Council noting the city's ranking among cities in San Mateo County of hosting the most payday lenders per capita in the county. This theme of Pacifica having a disproportionate number of payday lenders was repeated often and even found its way into the January 2011 resolution that established a 22-month-and-15-day moratorium on licensing new payday lenders in order to

allow the city time to study payday lending's impact on the community. ${ }^{171}$ Speaking to the Pacifica City Council in October, 2010, Rees recounted the story of a family that came to the Pacifica Resource Center for assistance: the family had payday loans from four different businesses (one of which was online) and was trying to pay off loans that came due by taking out a new one. ${ }^{172}$

\section{The East Palo Alto Campaign}

Whereas a moratorium on new payday lenders in Pacifica generated excitement and provided an early win from the point of view of SVCF and its partners, moratoria are by definition temporary. Indeed, as it turned out, Pacifica did not take any further action against payday 
lending when the moratorium expired in late 2012. This was not a big blow in the grand scheme of things, however, because opponents of payday lending in Silicon Valley had their eyes trained on a more ambitious target-a permanent ordinance that would prevent new payday lenders from opening for business in the area's largest city, San Jose.

SVCF seeded the effort to move beyond moratoria with a second request for grant proposals in November, 2010. In the invitation to submit proposals, SVCF indicated its interest in supporting efforts to "advocate changes in municipal laws and regulations that allow for excessive interest and service fees." 173 The request for proposals stated that proposals addressed to cities with high concentrations of payday lending establishments would be given priority. Four of the five grants awarded were designed to promote local anti-payday lending ordinances. Two of those grants were focused on Santa Clara County's largest city, San Jose, where payday lending stores were abundant. The first city in which grant recipients were successful in passing a permanent anti-payday lending ordinance, however, was East Palo Alto in San Mateo County.

East Palo Alto is the poor sister of affluent Palo Alto, home of Stanford University. The two cities are not separated by the proverbial railroad tracks, but they are separated by a major freeway. The cities are even in different counties (East Palo Alto in San Mateo County and Palo Alto in Santa Clara County). Despite some gentrification along its western border due to the city's proximity to companies like Google and Facebook, the majority of East Palo Alto's 30,000 residents are Latino, with the second largest group being African-Americans. Median household income in 2010 was around \$48,000-far less than the cost of attending Stanford for one year. ${ }^{174}$ The demographics of East Palo Alto would suggest that it would be attractive to payday lenders, but, strangely, East Palo Alto had no payday lenders within its borders when the ordinance was passed in late 2011, although borrowers could avail themselves of payday lenders in nearby Redwood City and via the internet.

The key organization in the effort to curb payday lending in East Palo Alto was Community Legal Services of East Palo Alto (CLSEPA). CLSEPA's first connection to SVCF took place in early 2009, when CLSEPA received a $\$ 75,000$ grant to assist homeowners facing foreclosure. ${ }^{175}$ In 2011, CLSEPA received another SVCF foreclosure grant but also a $\$ 50,000$ grant to support a collaborative campaign to pass a local ordinance and to redirect present and potential users of payday lending to other products. ${ }^{176}$ As explained by Keith Ogden of CLESPA, it was an easy jump from work on subprime mortgages to advocacy on payday lending because they both included predatory practices: "Just like subprime mortgage lending caused a debt trap that wreaked havoc on some people, payday loans create a debt cycle that wreaks havoc on others." 177

The campaign in East Palo Alto established a basic pattern that was repeated elsewhere in the moderate-size cities of Silicon Valley, and this approach expanded into a more elaborate and 
sophisticated effort in San Jose. Supported with funds from SVCF, the key campaign elements in East Palo Alto included:

(1) Building a coalition in support of the ordinance;

(2) Using traditional and new media;

(3) Putting the ordinance on firm legal ground by basing it on distances between payday lenders themselves and between payday lenders and certain other types of uses;

(4) Identifying a champion within the city council to help introduce and push forward the ordinance, while meeting one-on-one with city council members, and backing all of this up with well-planned testimony at public hearings; and

(5) Combatting industry arguments by offering alternatives to payday loans and promoting consumer education.

CLSEPA took the lead in pushing for a payday ordinance in East Palo Alto, but it led a looselydefined coalition. Nuestra Casa, a local organization devoted to promoting economic development and political participation among Latinos, was a particularly important partner. Nuestra Casa received grants from SVCF beginning in 2009, but in program areas separate from payday lending (Adult English Language Acquisition; Bridging the Cultural Gap). The willingness of Nuestra Casa to collaborate with CLSEPA on payday lending was one of many examples of what SVCF's Krackov called "cross-fertilization" across SVCF's programs. ${ }^{178}$

A notable example of the partnership between CLSEPA and Nuestra Case was co-production of a short film satirizing payday lending, titled "U-PAY-US." The film follows a new employee in a payday lending store as she is introduced to the tricks and traps of the industry by two seasoned co-workers. The film was written, directed, and edited by John Slattery, the spouse of CLSEPA attorney Leah Simon-Weisberg, and it premiered in East Palo Alto on June 30, 2011. ${ }^{179}$ The film was used to educate the public about the problems associated with payday lending and served to complement more traditional pamphlets explaining these loans and alternatives to them.

The legislative solution advocated by CLSEPA and its allies was an ordinance that incorporated features of ordinances that had been passed elsewhere in California (and in other states such as Utah). Accordingly, the ordinance would likely be immune to a legal challenge. Like Oakland and Oceanside in California, the ordinance would set minimum distances between one payday lender and another as well as between a payday lender and certain "sensitive" land uses. The latter would include residences, schools, and churches as well as bars and liquor stores. From the city of South Gate in the Los Angeles area, the East Palo Alto ordinance would incorporate 
the idea of setting time of day limits for payday lenders. Whereas South Gate restricted payday lending from 7 a.m. to 10 p.m., East Palo Alto's ordinance was stricter, making 7 a.m. to 7 p.m. the acceptable hours of operation. ${ }^{180}$

\section{The Political Process in East Palo Alto}

The city of East Palo Alto is governed by a five-member city council elected at-large to four-year terms. The mayor is selected from among members of the city council by majority vote of the council. Councilmember Carlos Romero had expertise in city planning and a long history of social and environmental justice. He was approached by CLSEPA about a possible ordinance. According to Keith Ogden, Romero understood the issue of payday lending quickly and gave his strong support to the concept of a payday ordinance. ${ }^{181}$

Feelings about the presence and absence of financial institutions in the city were raw at the time of the ordinance debate. In May, 2011, California Bank \& Trust, the city's only depository institution, announced that it would close its doors in August, citing a lack of profitability. ${ }^{182}$ Critics of the proposed ordinance, such as Councilmember Peter Evans, argued that banning payday lenders would leave people without options. He said: "Some of our residents have no choice. It [the payday industry] exists because there is a need. Some [residents] are undocumented, with no way to access [other] types of financial services." ${ }^{183}$ The strong leadership of Carlos Romero helped to counterbalance this perspective on the city council. It was helpful, too, that Romero was serving as mayor of the city in 2011.

The ordinance's community supporters pressed their position privately through one-on-one meetings with members of the city council as well as publicly via testimony at public hearings held by the city council and the city planning commission. Fifteen and six people testified at these hearings, respectively. Fernando Peña, government affairs director for payday lender Cash America, and Ogden of CLESPA anchored the two sides at both hearings. Peña drew support from representatives of other payday lending companies, while Ogden had more diverse allies with activists representing youth and the elderly in East Palo Alto speaking in favor of the ordinance as well as the pastor of a predominantly African American church. SVCF's Krackov also weighed in, stressing the cycle of debt that payday borrowers often enter and the economic impact on the city's residents. ${ }^{184}$

Opponents of the ordinance made a number of arguments. Most challenging among them for ordinance advocates was the question of alternatives. If you make payday loans difficult to obtain, what are you going to offer people as an alternative? Ordinance supporters were not surprised by this argument, however. Indeed, the CLSEPA 2011 grant from SVCF had two objectives: to direct a collaborative campaign to focus on a local ordinance and to redirect present and potential users of payday lending to other alternative products, and CLSEPA and its 
partners already developed a hierarchy of responses to short-term financial needs. First in the progression was borrowing from friends and family. The next option was non-payday lenders, including credit unions, community development financial institutions and other new entrants to the financial services field offering loans on non-predatory terms. The final suggested alternative was turning to social service agencies for emergency assistance, for example to pay a utility bill or even rent.

Coping with the need for immediate cash without resorting to payday lenders was one thing, but SVCF and other ordinance supporters also emphasized financial literacy and asset building as the keys to making payday loans unnecessary. Toward these ends, groups like CLSEPA, Nuestra Casa, and the entrepreneurship-oriented Renaissance Mid-Peninsula offered consumer education classes to help individuals develop the financial skills to free them from needing to turn to payday loans. Nuestra Casa even began offering education about payday lending into a class for undocumented residents seeking a driver's license under a new California law: the logic went that getting a license involves buying a car, and buying a car entails understanding credit, and understanding credit includes avoiding high-cost forms of borrowing such as payday loans. ${ }^{185}$ In Pacifica, PRC has also developed a small-scale program to help borrowers pay off payday loans and build savings to cover future emergencies. ${ }^{186}$ In the spring of 2011, when only Pacifica had a payday lender moratorium and no other cities yet had ordinances, SVCF's CEO and President, Emmet Carson, was quoted as saying: "The financial literacy piece of this is the core. I can't stress that enough. You need to understand how to budget, the appropriate uses of credit, and cash flow." ${ }^{187}$

\section{Ordinance Enactment in East Palo Alto}

On November 14, 2011 the East Palo Alto Planning Commission voted 5-0-1 in favor of the ordinance, and the City Council passed the ordinance two weeks later by a vote of 4-1. ${ }^{188}$ At one level, the ordinance was purely preventative given that there were no payday lenders in East Palo Alto. This meant that the various distance requirements between any two payday lenders as well as the minimum distance requirements between a lender and residential, religious, and school buildings were unlikely to have any immediate effect. Viewed more broadly, though, the campaign to pass the ordinance created a playbook that would be successfully transferred to other communities in Silicon Valley, many of whom had large numbers of payday lenders.

Indeed, within five years, approximately a dozen jurisdictions in the two-county Silicon Valley area had passed ordinances similar to the one pioneered in East Palo Alto. These campaigns relied on the efforts of additional advocacy organizations, including the California Reinvestment 
Coalition, the Youth Leadership Institute, and others. The biggest prize, however, was the city of San Jose, where a much broader coalition and more intense community organizing was required to pass an ordinance covering a million people.

\section{The San Jose Campaign}

San Jose, with a population of over one million people, is California's third largest city (behind Los Angeles and San Diego). European settlement in the area dates back to the 1770s. The first census in 1778 showed 68 people of different races living there. Today, the city is highly diverse in terms of race and ethnicity. The U.S. Census Bureau reports that about $33 \%$ of San Jose residents are Hispanic or Latino. Another $32 \%$ are Asian and $28 \%$ are White. ${ }^{189}$

Judged by household median income, the city of San Jose is one of the wealthiest cities in the United States. ${ }^{190}$ Many of its residents commute through heavy traffic to find lucrative employment at the many high-tech companies headquartered throughout the Bay Area. (More people commute out of San Jose each day than commute into it. ${ }^{191}$ ) Income inequality in San Jose is higher than the national average but on par with that of California as a whole. ${ }^{192}$ According to the California Budget \& Policy Center, in a report supported by SVCF, household incomes in Silicon Valley have grown further apart over the last twenty-five years as the region's income gains have been enjoyed almost entirely by high-income households. ${ }^{193}$ Meanwhile, low-income households have actually seen income declines over the past generation. A low-income household in San Mateo, Santa Clara, and San Francisco counties has a lower income today than a similar household would have had in 1989, after adjusting for inflation, meaning that there is now a wider gap between Silicon Valley's higher-income households and the region's lower-income households than twenty-five years ago. ${ }^{194}$ Despite its overall prosperity, payday lenders have been attracted to San Jose, and as of 2009, when the effort to control them began, the city was home to thirty-nine payday lenders. ${ }^{195}$

Finding a Campaign Leader for San Jose

When SVCF decided in 2009 to target payday lending as part of its initiative on economic security, it knew it could rely on CRC and CRL, but SVCF had no obvious, Silicon Valley-based leader for a campaign that would seek an anti-payday lending ordinance in San Jose. ${ }^{196}$ The Law Foundation of Silicon Valley ("Law Foundation") stepped up to the challenge. The Law Foundation's mission is to advance "the rights of under-represented individuals and families in our diverse community through legal services, strategic advocacy, and educational outreach."197

Work on payday lending was new to the Law Foundation. Kyra Kazantzis, one of the Law Foundation's key leaders throughout its payday lending work, admitted to being a bit surprised 
when she heard that the Law Foundation was going to write a report for SVCF on payday lending. She thought that the Law Foundation might have been chosen to do the research precisely because it had not been involved in payday lending work. That way, its findings could be viewed as relatively unbiased. Kazantzis soon saw, though, that addressing payday lending was a natural extension of the Law Foundation's previous work on mortgage lending and foreclosure. Moreover, in the process of conducting research for the report, Kazantzis and her co-authors interviewed people who had already been engaged "on the ground" in ordinance work, and they began speaking with people like CRC's Liana Molina. These conversations got Kazantzis excited about doing additional work on payday lending. ${ }^{198}$ When SVCF's RFP came out in June 2009, the Law Foundation was eager to submit a proposal.

On October 15, 2009, SVCF announced its first round of grants for anti-payday lending policy advocacy and made three awards totaling over $\$ 400,000$, the largest of which went to the Law Foundation. ${ }^{199}$ The purpose of the $\$ 255,000$ grant to the Law Foundation was to "establish a San Jose anti-payday lending coalition" that would educate, mobilize, and advocate "for public policy that addresses the growth of payday lenders in low- and moderate-income neighborhoods and communities of color." ${ }^{200}$ The resulting coalition engaged in a three-year campaign that culminated in the passage of a payday lending ordinance in San Jose as well as several other key jurisdictions in Santa Clara County.

The table below describes SVCF's extensive grant-making with respect to anti-payday lending reform for the 2009-2016 period.

Figure 3: Grantees in SVCF Anti-Payday Lending Program by Year and Total

\begin{tabular}{|c|c|c|c|c|c|c|c|c|}
\hline GRANTEE & 2009 & 2011 & 2012 & 2013 & 2014 & 2015 & 2016 & Total \\
\hline $\begin{array}{l}\text { City of San } \\
\text { Jose }\end{array}$ & & $\$ 50,000$ & & & & & & $\$ 50,000$ \\
\hline $\begin{array}{l}\text { Community } \\
\text { Legal Services } \\
\text { of East Palo } \\
\text { Alto }\end{array}$ & & $\$ 50,000$ & $\$ 75,000$ & $\$ 50,000$ & $\$ 60,000$ & $\$ 55,000$ & $\$ 50,000$ & $\$ 340,000$ \\
\hline $\begin{array}{l}\text { California } \\
\text { Reinvestment } \\
\text { Coalition }\end{array}$ & & & & & $\$ 125,000$ & $\$ 125,000$ & $\$ 125,000$ & $\$ 375,000$ \\
\hline $\begin{array}{l}\text { Center for } \\
\text { Responsible } \\
\text { Lending } \\
\end{array}$ & $\$ 100,000$ & $\$ 100,000$ & $\$ 75,000$ & $\$ 130,000$ & $\$ 125,000$ & $\$ 100,000$ & $\$ 100,000$ & $\$ 730,000$ \\
\hline $\begin{array}{l}\text { Housing and } \\
\text { Economic } \\
\text { Rights Center }\end{array}$ & & & & & & & $\$ 45,000$ & $\$ 45,000$ \\
\hline $\begin{array}{l}\text { Insight Center } \\
\text { for }\end{array}$ & $\$ 72,000$ & $\$ 100,000$ & $\$ 60,000$ & $\$ 26,000$ & & & & $\$ 258,000$ \\
\hline
\end{tabular}




\begin{tabular}{|c|c|c|c|c|c|c|c|c|}
\hline $\begin{array}{l}\text { Community } \\
\text { Economic } \\
\text { Development }\end{array}$ & & & & & & & & \\
\hline $\begin{array}{l}\text { Law } \\
\text { Foundation } \\
\text { Silicon Valley }\end{array}$ & $\$ 255,000$ & $\$ 200,000$ & $\$ 250,000$ & $\$ 250,000$ & $\$ 238,500$ & $\$ 237,000$ & $\$ 250,000$ & $\$ 1,680,500$ \\
\hline $\begin{array}{l}\text { Policy \& } \\
\text { Economic } \\
\text { Research } \\
\text { Council }\end{array}$ & & & & & & $\$ 75,000$ & & $\$ 75,000$ \\
\hline $\begin{array}{l}\text { Public Justice } \\
\text { Foundation }\end{array}$ & & & & & & $\$ 50,000$ & $\$ 65,000$ & $\$ 115,000$ \\
\hline $\begin{array}{l}\text { Youth } \\
\text { Leadership } \\
\text { Institute }\end{array}$ & & & & $\$ 125,000$ & $\$ 125,000$ & $\$ 125,000$ & $\$ 125,000$ & $\$ 500,000$ \\
\hline Total & $\$ 427,000$ & $\$ 500,000$ & $\$ 460,000$ & $\$ 581,000$ & $\$ 673,500$ & $\$ 767,000$ & $\$ 760,000$ & $\$ 4,168,500$ \\
\hline
\end{tabular}

Source: Silicon Valley Community Foundation

Shaping the Coalition that Would Move San Jose

Facilitated by the financial resources and engagement of SVCF, the Law Foundation (in the form of its Public Interest Law Firm), with strong involvement from the California Reinvestment Coalition, was able to pull off a textbook example of community organizing. It involved building a campaign organization and generating support from other organizations, influencing public opinion, and participating in the policy-making process of city governments.

The centerpiece of the campaign was the creation of the Coalition Against Payday Predators, or CAPP. Under the auspices of the Law Foundation, CAPP formed an alliance of community organizations that were based in or worked extensively in Santa Clara County. Eventually, there were eleven core members, all of whom received direct or indirect funding from SVCF'S Economic Security program at one point during the 2009-2012 period. ${ }^{201}$ CAPP's leaders also built up a list of more than thirty "organizational endorsers." These endorsers added legitimacy to the campaign and, at key points, political clout as well. They added legitimacy by virtue of the diverse constituencies they represented, including Latinos, African Americans, the elderly, religious organizations and labor unions. The endorsers added political clout by helping to find individuals who had experienced the dangers of payday lending and were willing to speak out as well as take part in teams of ordinance supporters to meet with individual members of the San Jose City Council.

James Zahradka, an attorney at the Law Foundation between 2001 and 2015, believes that his organization's ability to successfully manage a broad coalition was predictable but not guaranteed. The Law Foundation's Public Interest Law Firm had pre-existing relationships with 
many of the eventual core members of CAPP, including Alliance for Californians for Community Empowerment, the Asian Law Alliance, and Sacred Heart Community Services. ${ }^{202}$ These prior alliances allowed CAPP to develop organically. Nevertheless, the Law Foundation's core skill was litigation. It embraced public policy advocacy, but it had never led a coalition before. ${ }^{203}$ In the process of gaining organizational endorsers, the effort to gain the support of La Raza Roundtable de California (Roundtable) for an ordinance in San Jose was particularly important and challenging. Every community has its influential non-governmental groups, and in San Jose, The Roundtable was one. Thirty-three percent of San Jose's residents are Latino, but equally important, there is a strong identification with the life of Cesar Chavez among many of San Jose's older Latino political leaders. Chavez lived in San Jose as a teenager and young adult, and he began his career as a community organizer there. As a result, the political positions of the La Raza Roundtable carry considerable practical and symbolic weight in San Jose.

The goal of the Roundtable is to improve the quality of life for Chicanos, and it aims to do so in an inclusive fashion that welcomes all people. ${ }^{204}$ It meets every month on a Friday night. According to Kyra Kazantzis of the Law Foundation, "It's a huge meeting with perhaps seventy people in attendance. The police chief is there. The district attorney is there. Five city council members are there." ${ }^{205}$ Anyone is welcome to attend and speak, but you can't just show up and expect to have credibility. Kyra Kazantzis introduced herself to the Roundtable's long-time chairman, Victor Garza, and began to attend regularly, bringing up the subject of payday lending at every opportunity. To speak privately with the Roundtable's board of directors, Kazantzis enlisted the help of a friend, Deputy District Attorney Chris Arriola. Arriola is a respected Latino leader in San Jose and was able to open the door to the Roundtable's board for Kazantzis, and after hearing from her about the abuses of the industry, especially on lowincome, communities of color, the Roundtable agreed to sign on as an organizational endorser of CAPP.

Candidates for San Jose City Council often seek the Roundtable's stamp of approval. During the candidate interviews, the Roundtable's Board would ask questions regarding issues of importance to the Latinx community. Kazantzis reflected on how this played out with respect to the anti-payday lending advocacy campaign:

"It was gold. One of the candidates was asked about payday lending and whether she supported an ordinance. She said she did, and, ultimately, two years later, she voted for it. I always thought that the commitment she made to the Roundtable Board solidified her vote.". 206

The support of the Roundtable continued to be important during the campaign because Manny Diaz, another Latino leader and a former member of the San Jose City Council, was a registered 
lobbyist for the payday lending trade association, the Community Financial Services Association of America. ${ }^{207}$ In addition, the California Hispanic Chamber of Commerce was one of the few opponents of the ordinance other than the payday industry itself. ${ }^{208}$

\section{Reaching Beyond the Coalition in the San Jose Campaign}

Successful efforts to bring about policy change typically require an "inside game" and an "outside game." 209 The inside game consists of efforts to directly influence political decision makers. These methods of persuasion include meeting with government officials and members of their staffs, providing them with technical reports, and making campaign contributions. Playing the inside game is greatly enhanced when groups that are seeking policy change have an "inside champion," a political decision maker who seeks the same policy change and can lobby fellow decision makers. ${ }^{210}$ Just as City Council member Jerry Allen had served as an inside champion in Dallas; Ash Kalra would play a similar role on the San Jose City Council (Rose Jacobs Gibson would take on this role on the San Mateo County Board of Supervisors, Mike Guingona would do likewise on the City Council of Daly City, along with additional political leaders in other Silicon Valley jurisdictions).

A strong inside game is best complemented by an effective outside game-the education and mobilization of members of the public. Because public policies typically impose costs on some segments of societies, political decision makers rarely act until pressed. The role of the outside game it to create that pressure by changing the public climate in which policy decisions are made. Most often, the outside game involves creating media content (e.g., creating a website; buying advertising) or earning media coverage (e.g., television stories, newspaper editorials).

CAPP developed an extensive outside game. By September 2010, it had a website. CAPP's outreach efforts also benefited from a focus group study funded by SVCF, commissioned by the Center for Responsible Lending's California office, and conducted by the opinion research firm of Goodwin Simon Strategic Research. ${ }^{211}$ The study's results were based on four focus groups composed of low-income residents of the greater San Jose area. Three of the focus groups contained people who had taken out a payday loan within the last year, one group each for African-Americans, Latinos (conducted in Spanish), and Anglos. The participants in the fourth group were mixed-race and mixed-ethnicity and had not taken out a payday loan within the last year, including some people who had never had this type of loan.

The focus group study confirmed that some payday customers feel trapped in a frustrating cycle of debt, and many payday customers feel shame or embarrassment for not being in better control of their finances. Yet, the report yielded some surprising results. One was that borrowers do not appreciate being told that their decision to rely on a high-cost payday loan did not make financial sense. They view credit cards as more dangerous than payday loans, and 
they rejected advice in a flyer shown to them that recommended applying for a credit card as an alternative to relying on a payday loan. Moreover, focus group participants felt that at least the fees associated with a payday loan were clear at the outset, as opposed to the surprise fees that many banks levy. Far from being unsophisticated consumers who take out payday loans because they are a person's only contact with a financial institution, some borrowers used online banking to monitor account balances or make bill payments. Finally, many participants considered the terms of payday loans to be fair and transparent. Almost all of the participants seemed to know the exact amount of the non-sufficient-funds fees charged by banks in the event of exceeding debit or credit card limits. While some people said they would find other ways of managing their finances if payday loans were banned, others were not sure how they would cope.

From the point of view of CAPP's leaders, the most important take-away from the focus groups is that payday borrowers are more sophisticated than generally believed and are likely to resent any portrayal of them as being "ignorant pawns" of the payday lenders. They admit to holding negative views of people who rely on payday loans, but they do not want others to judge them badly on this basis because they take out payday loans when they are desperate and perceive no better alternatives. CAPP would soon modify its messaging in light of the focus group findings. Rather than emphasizing borrower victimization, CAPP framed its message in terms of the right of all people to healthy and safe financial products. ${ }^{212}$

A second study conducted for CRL by Goodwin and Simon in November 2010 revealed that half the members of a sample of registered voters in San Jose supported tighter regulation of payday loan stores, but if CAPP's goal was to push public opinion further in the direction of supporting a payday ordinance in San Jose, CAPP would have to rely on messages carried in the mass media. ${ }^{213}$ To this end, representatives of CAPP, including Kazantzis and Paul Leonard of the Center for Responsible Lending, met with the editorial board of San Jose's major daily newspaper, the San Jose Mercury News, and contacted its reporters. Cause and effect is difficult to unravel, but CAPP found a receptive audience at the paper. Reporter Karen de Sá covered the campaign to pass an ordinance in San Jose, although her stories often spent more space addressing the power of payday lenders in the state legislature than developments in San Jose. ${ }^{214}$ The editorial board at the newspaper weighed in unequivocally in favor of a strong ordinance-twice before its passage and once immediately after it. ${ }^{215}$ In the second editorial, the newspaper urged the city council to go beyond the distance requirements being considered by the Santa Clara County Board of Supervisors and enact a numerical cap on the lenders. It wrote: "San Jose has 38 of them. That is more than enough." 216

Local television news programs also devoted time to the San Jose ordinance process. A December 17, 2010 story on KCBS-TV about a discussion of payday lending by the Rules 
Committee of the San Jose City Council began: "We've told you about them before-predatory lenders who promise payday loans to low-income people only to charge some massive fees, and there's been a huge influx of those businesses into San Jose recently." ${ }^{217}$ The story included interviews with three payday borrowers, several of whom testified to the cyclical nature of payday loans - taking out a new one to pay off a previous one. The story attributed the phrase "legalized loansharking" to San Jose Mayor Chuck Reed as a descriptor of payday lending.

\section{Engaging in the Policy-Making Process in San Jose}

Many smaller cities in the Bay Area are governed by a five-person city council, with the position of mayor rotating among the council members. In contrast, San Jose has a "council-manager" form of government. There are eleven members of the city council, ten of whom are elected in districts. The eleventh member of the council is the mayor, who is elected city-wide. Terms of office for all members of the council, including the mayor, are four years, with a limit of two consecutive terms. In late 2010 when the city of San Jose began to address in earnest a possible payday lending ordinance, Mayor Chuck Reed was beginning his second term in office. Ash Kalra, who was to serve as the ordinance's strongest support on the council, was in the middle of his first term in $2010 .^{218}$

The leaders of CAPP had used most of 2010 to get their alliance organized and obtain the endorsements of key community groups. In December, it was time for CAPP to begin its inside game and participate directly in the policy-making process. ${ }^{219}$ The issue at hand was whether the City of San Jose would apply for a request for proposals issued by SVCF. Time was short because the deadline for submissions was January 5, 2011. On December 9, 2010, Kalra and newly-elected councilmember Xavier Campos addressed a memo to the mayor and city council recommending an application be submitted. ${ }^{220}$ If funded, city staff members would be directed to draft an ordinance that would establish a moratorium on permits or licenses for additional payday lenders. In addition, the funding would cover the expense of city staffers drafting an ordinance that would require the issuance of a special use permit prior to the establishment of any new payday loan businesses; enact distance and density restrictions; require greater disclosure of payday loan terms to potential borrowers; set minimal security and anti-blight measures; and limit hours of operation. Finally, the grant would also be used to coordinate and conduct an outreach process with key stakeholders.

The memo would be discussed at the December 15 meeting of the City Council's Rules and Good Government Committee. CAPP issued an action alert to its members, encouraging them to attend the afternoon meeting or contact members of the Rules Committee by phone or mail. ${ }^{221}$ At the meeting itself, three of CAPP's core members who fund or provide direct services to thousands of low-income families (United Way Silicon Valley, Catholic Charities of 
Santa Clara County, and Sacred Heart Community Service) spoke in favor of the grant, as did two payday borrowers. ${ }^{222}$ In light of this support, the members of the Rules Committee voted to apply for an SVCF grant.

Mike Cassidy, a columnist for the San Jose Mercury News, congratulated the city council for its decision. He wrote: "The city is taking baby steps. But even talking about enacting restrictions has raised the profile of payday loans and the fiscal havoc they wreak. And maybe the city can adopt its own New Year's resolution: Get that grant and get to work." ${ }^{223}$ Not everyone was so pleased. Mayor Reed received at least one letter of protest. Along with calling for an investigation of SVCF and insulting councilmembers Kalra, Liccardo and Campos, the letter writer insulted borrowers as well, asking: "Should San Jose rescue the stupid?"224

On March 16, 2011, SVCF announced a grant of $\$ 50,000$ to the City of San Jose for the purpose of conducting research on the development of a local ordinance that would regulate the location of payday lending establishments. ${ }^{225}$ Although accepting the grant did not commit city leaders to passing an ordinance, it certainly increased the likelihood of one passing. Whereas the City's grant proposal had identified July-December 2011 as the timeframe during which grant activities would be carried out, the city's managers asked SVCF for an adjusted timetable. Under the new schedule, work would begin in August 2011 and last until February $2012 .{ }^{226}$

One interpretation of the delay was that the commitment of the city council to the grant had been weakened by industry lobbying. Manny Diaz, a former San Jose city councilmember and state assembly member, was then working as a registered lobbyist for the Community Financial Services Association of America. During January, Diaz met, typically more than once, with eight of the ten city councilmembers as well as staffers for the mayor and city manager. ${ }^{227}$ Councilmember Ash Kalra, a strong supporter of the grant and the ordinance, provided a less nefarious explanation for the delay. It was simply attributable to higher priority matters that had been officially set for city staff in February and the uncertain impacts of likely budget cuts. $^{228}$ Kalra reported that support for the ordinance remained strong. In either event, SVCF granted the city's request to delay working on the grant until August 2011.

CAPP members wanted to make sure that when the City of San Jose revisited its top priorities in August, consideration of a payday lending ordinance would be considered urgent. At the August 30, 2011 meeting of the San Jose City Council, representatives of several CAPP member organizations offered public comments. These people were: Richard Konda of the Asian Law Alliance; Liana Molina of the California Reinvestment Coalition; Steve Preminger of the South Bay Labor Council; Ricky Alexander of Sacred Heart Community Services; and Kyra Kazantzis from the Law Foundation of Silicon Valley. ${ }^{229}$ The City Council then voted to add three issues to its "top ten," and payday lending was one of the three. ${ }^{230}$ 
Before an ordinance could be passed, CAPP organizers knew, they would have to make their case in front of San Jose Planning Commission and then the City Council. In preparation, they focused on three strategies: finding borrowers who were willing to speak about their problems with payday loans in a highly public setting, rebutting industry arguments about the need for payday loans, and pressing their case in meetings with city councilmembers.

Finding payday borrowers was relatively easy for CAPP; getting them to agree to tell their stories in public was a bigger challenge. Two members of CAPP-Sacred Heart Community Services and Somos Mayfair-were especially helpful in identifying payday borrowers. Christian Luna, a program manager at Sacred Heart, explained how the process worked. Sacred Heart, like Somos Mayfair and several other CAPP members, is a non-profit social service organization that provides essential services for individuals and families in need and tries to put them on the path to economic self-sufficiency. As part of its financial education classes, clients filled out pre- and post-questionnaires to assess learning. Luna added a question to the pre-class survey: Do you or anybody you know have any experience with payday loans? ${ }^{231}$ A few months passed before Luna analyzed the results. He was surprised to find that a quarter or more of their workshop participants answered in the affirmative. He said: "So we knew that payday lending was a significant issue, something that definitely impacted our base of clients at Sacred Heart. We realized that it was something that we could definitely begin getting more deeply involved in, and we partnered up with the Law Foundation to figure out what our next steps should be." 232

Once payday users were identified among Sacred Heart's clients, Luna would ask them whether they would be willing to talk about it. If they were, they met with a community organizer, Ricky Alexander, who helped prepare them to share their testimony.

On paper, the process of recruiting people to speak in public about their experience with payday loans sounds simple, but the process was challenging and extremely time consuming. The focus group research conducted for CRL showed that borrowers, even when they did not blame themselves for taking out payday loans, know that other people think they are stupid or irresponsible for doing so. Borrowers realize there is a stigma attached to taking out a payday loan, taking months to repay it, and racking up huge fees and interest payments. Other potential "witnesses" to the ravages of payday loans were afraid to speak in public because English was not their first language. Thus, it took considerable time for community organizers such as Ricky Alexander to help clients feel comfortable with the idea of testifying at a city forum. 


\section{Planning Commission Testimony in San Jose}

CAPP's efforts to recruit and prepare borrowers to speak publicly about their negative experiences with payday loans resulted in testimony at city government meetings in San Jose and elsewhere. At the April 25, 2012 meeting of the San Jose Planning Commission, Ricky Alexander led off by describing the efforts made by Sacred Heart to fight poverty through financial education and assistance in finding a job. He said:

We work with families to help them repair their credit ... when we hear that families have taken out payday loans in the past and regret the experience. We are doing our part. We are even engaging families in advocacy so they have the opportunity to make their voices and experiences known as you'll hear tonight. Tonight is [about] what you're able to do. Knowing predatory practices happen in our own backyard what are you going to do about it? ${ }^{233}$

Alexander's testimony was followed by that of Evelyn Bonado and Shane Randolph Virtue, both of whom described the pitfalls and high cost of payday lending. ${ }^{234}$ Matt King, a community involvement advocate at Sacred Heart, read a statement from a bar owner named Maurice, who felt "too much shame to come out and tell his story." 235 Maurice told of using a payday loan to cover some bills and then getting a succession of loans to cover the previous ones. His testimony continued:

When I was finally able to secure a few hours of part time work, the payday shops went into my bank account, without notifying me, and took the money I had to pay back the Ioan I owed. Instead of offering me a reasonable payment plan with incremental payments they raided my account when I was finally getting back up on my feet. I was broke all over again. ${ }^{236}$

In support of an ordinance, the Commission also heard from representatives of core organizations in CAPP that, like Sacred Heart, work directly with the people who are most likely to borrow from payday lenders. These speakers were: Step-Up Silicon Valley/Catholic Charities of Santa Clara County, Alliance of Californians for Community Empowerment, Community Homeless Alliance Ministry, and Working Partnerships USA.

In total, about thirty people spoke in support of an ordinance. Two were especially noteworthy. Pat Krackov spoke on behalf of SVCF, signaling the foundation's willingness to lobby alongside its grantees in support of Silicon Valley's low-income communities. Another was Karyn Sinunu-Towery, assistant district attorney for the County of Santa Clara. ${ }^{237}$ SinunuTowery urged adoption of a cap on the number of payday loan outlets in San Jose. Members of the Planning Commission took note of the participation of the assistant district attorney. Commissioner Norman Kline commented: "It is not very common for us to get a letter from our 
District Attorney. It's not very common for our District Attorney representative [to be] talking here about land use issues."238 Kyra Kazantzis of the Law Foundation observed that the members of the Planning Commission treated Sinunu-Towery with deference and concluded that the county's support of an ordinance was "huge." 239

In terms of justifying an ordinance, supporters drew attention to the high cost of payday loans and the "cycle of debt" into which many borrowers become trapped. Payday loan fees and interest rates were described as "exorbitant" and "unconscionable." None of the witnesses cited blight, decline in property values, crime, or other negative spillovers/secondary effects of payday loan establishment as the rationale for their support of an ordinance, instead their arguments were based on empathy with borrowers rather than community economics.

The people who spoke against payday lending and for an ordinance were important because there were three speakers who defended the industry as well-all employees or owners of payday stores. There were no lobbyists for the industry as a whole, although the Community Financial Services Association of America submitted a comment letter a day prior to the hearing. 240

Those who spoke in opposition to an ordinance made a variety of arguments. The opponents pointed out that taking out a payday loan can be less expensive than bouncing a check. They argued that payday lenders are employers, so curtailing these lenders would cause job losses. Their most fundamental point was that payday loans meet a consumer need. They help people cope with financial hardship when they have no other options. If payday loans become less available, what alternatives will be available?

The issue of payday loan alternatives was a legitimate one, so much so that SVCF and the members of CAPP had been developing a response to it from the beginning of their campaign. In December 2010, SVCF co-sponsored with the Federal Reserve Bank of San Francisco a conference for leaders of financial institutions, social service agencies, policy institutions and government to learn about payday loans and alternative products. ${ }^{241}$ Later that month, Emmett Carson, SVCF's president and CEO, discussed payday loan alternatives on the Bay Area's main public radio station, KQED, describing what a payday loan is and then explaining that while the loans are not bad in concept, "predatory payday loans charge exorbitant interest rates, upward of $400-500 \%$, which we believe at the Community Foundation are usurious. "242 In the immediate run-up to the discussion of a possible ordinance by the San Jose Planning Commission and City Council, CAPP ran a public forum called "When Cash Runs Out: Discussing the Alternatives." ${ }^{243}$ These activities identified a wide range of short-term loans from credit union and employers; lending circles; bill forbearance programs run by utility companies; and borrowing from friends or family; along with longer-term options (e.g., financial education, 
increase in the minimum wage, and creating emergency savings). At the hearing, ordinance supporters were able to state confidently that alternatives to payday loans existed.

Overall at the hearing, supporters of an ordinance outnumbered opponents by a ratio of at least 5 to 1 . With the preponderance of speakers favoring an ordinance, some commenters spoke to the specific features an ordinance might contain. Two issues received particular attention. One was the minimum distance that would separate payday lenders from each other and from sensitive users such as churches and residences. Several speakers urged that the ordinance go beyond the 500 feet minimum found in some ordinances, such as Oakland's, in favor of a distance of 1000 or 1320 feet (a quarter mile). A second issue was whether the number of lenders should have a numerical cap and, if so, at what level. Some speakers supported a cap that reflected the current number of lenders in San Jose (38), while others recommended a cap in the range of 20 or 25 so that the number of lenders would decline when stores moved or closed. Kyra Kazantzis of the Law Foundation described a cap as the "gold standard across the country," although it was something that other cities in California had not done yet. $^{244}$

At the end of the discussion, the members of the Planning Commission voted 6-0-1 to recommend to the City Council approval of a proposed ordinance that would require new payday loan establishments to be separated by a quarter mile from another payday lender or from any low-income census tract. The initial motion, made by Commissioner Hope Cahan, would have capped the number of establishments at twenty and imposed an immediate moratorium on the approval of any new establishments, but these two features created resistance from some commissioners. In the end, the Planning Commission recommended that its staff provide information to the City Council that would help it decide whether to establish a limit on the number of payday lending establishments. The Commission was silent on the option of a moratorium. ${ }^{245}$

\section{San Jose City Council Meeting}

The San Jose City Council was scheduled to meet on May 15, 2012, to consider the final ordinance. Five days earlier, the Mayor and the Council received a memo from Joseph Horwedel, director of planning, building, and code enforcement for the city, addressing the unresolved question of whether to include a limit or cap on the total number of payday lending establishments in San Jose. The memo recommended against a cap, beginning with the observation that "no other city of comparable size in the State of California or in the nation currently imposes a specific limit (or "cap") on the number of payday lenders within their jurisdiction." ${ }^{246}$ The memo expressed the view that an ordinance without a cap would be sufficient to address problems related to the location of payday lenders. The memo also cautioned that "imposing a cap will create a new and unique regulatory/monitoring process 
that will require additional staffing resources." ${ }^{247}$ A final reason for opposing a cap could have been read as an indictment of the whole idea of an ordinance:

A cap will reduce potential competition within the payday lending industry and thereby reduce economic pressure that could lead to reduced rates or fees for payday loans. Establishing a cap will potentially raise the value of existing payday lending businesses and thus promote their long term economic viability. ${ }^{248}$

If the Council nonetheless decided to include a cap in the ordinance, the memo pointed out that four options existed: a cap at the current number of lenders (thirty-eight), a cap above that number, a cap below that number, or a density limitation on the number of lenders per capita.

In the weeks and months leading up to the May 15 meeting of the City Council, members of CAPP had attempted to meet with as many members of the Council (and their staff) as possible. By virtue of the breadth of the coalition, CAPP was typically able to bring a group of people, each selected because of his or her potential to be persuasive to a particular councilmember. For example, citizens who lived in a councilmember's district were preferred to citizens who lived outside it. For some councilmembers, representatives of organized labor might be most appropriate; for others, people of a particular ethnicity, race, or social class might be especially appropriate. CAPP's members knew that the votes of several councilmembers were certain to be cast in favor of an ordinance, but Councilmember Kalra was limited in his ability to provide inside intelligence to his allies in CAPP. The state's Brown Act sets a limit on the number of people who may be present at informal, behind-the-scenes meetings involving elected officials. ${ }^{249}$ As a result, ordinance supporters remained anxious as the meeting of the City Council was called to order.

The payday ordinance was not considered until after a long list of less controversial matters. Councilmember Kalra moved for approval of the ordinance as recommended by the Planning Commission with one exception. The ordinance would include a cap of thirty-nine on the number of payday lenders in the city. Councilmember Campos seconded the motion. ${ }^{250}$ Next, came the public comment portion of the meeting. The minutes of the meeting indicate that forty-four people expressed support for the ordinance, the majority of these people having an affiliation with one of the organizations in CAPP. The minutes provide the names of eight people who opposed the ordinance. The minutes also note five hundred letters submitted for the record in opposition to the ordinance, all dated that day.

Discussion among the councilmembers was brief. The final vote was 9-1-1, with Councilmember Pete Constant voting no, and Councilmember Rose Herrera being absent. The minimum distance separating payday loan establishments from each other was 1,320 feet. In two other respects, the final ordinance was unprecedented. Not only did San Jose become the 
only city of its size to impose a cap on the number of payday lenders, but it was also the first to prevent new payday lending businesses from opening in or near the boundaries of a census tract of the city designated as "very low income" based on median household income. ${ }^{251}$ Councilmember Kalra described the city's decision as a response to the inaction of the state legislature, and he and other councilmembers hoped that their stance on the payday issue would send a clear message to state leaders. ${ }^{252}$

To drive home the anti-payday loan message in San Jose, CAPP purchased advertisements on the sides of buses that circulated throughout Santa Clara County. The ads were printed in various combinations of English and Spanish. ${ }^{253}$ An example is found below.

Figure 4: CAPP Side-of-Bus Messages in San Jose

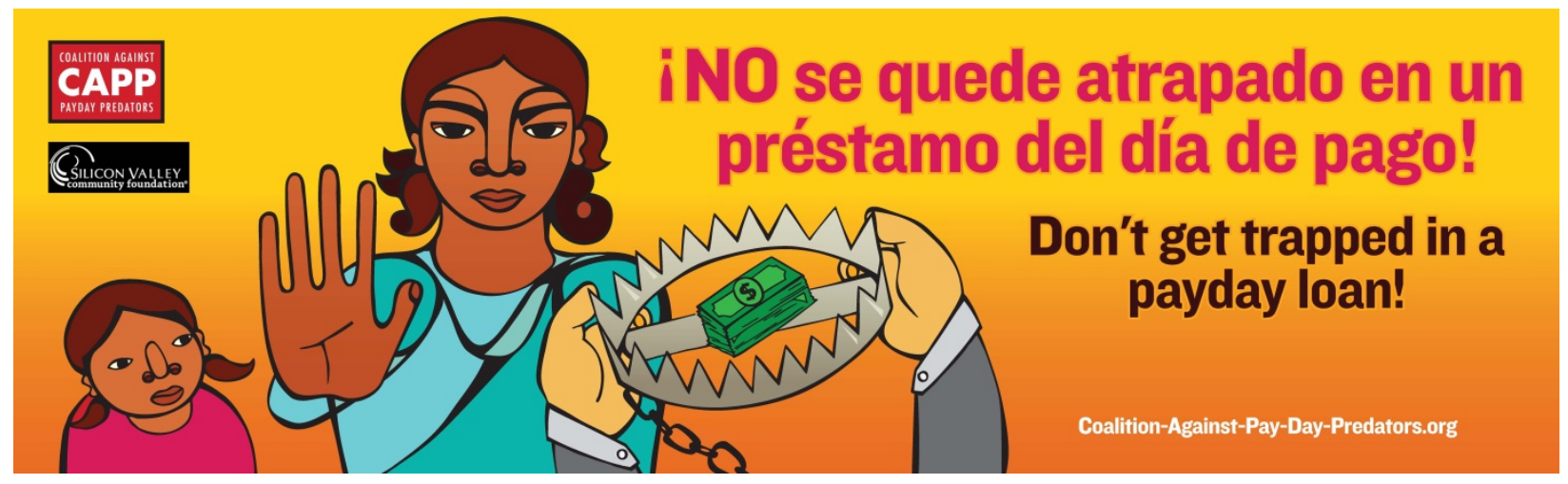

Image courtesy of Kyra Kazantis

Using images from the same artist, CAPP also distributed brochures in English and Spanish that explain how payday loans work, how they create a cycle of debt, how to cope with a financial emergency without resorting to a payday loan, and how to develop a long-term savings plan.

\section{Youth-Led Campaigns in Daly City and South San Francisco}

One of the more unique approaches supported by SVCF's anti-payday lending work was its support of two organizations that build skills of low-income, at-risk young people through leadership development programs so that they can help create more equitable communities. The organizations-Mission SF Community Financial Center (now named MyPath) and the Youth Leadership Institute, or YLI-view young people as "the most effective social architects" of social change." ${ }^{254}$ Youth development includes the ability to work with peers and adults, including local elected officials.

YLI was the lead organizer of the youth-led ordinance campaigns in Daly City and South San Francisco. Since 1991, youth involved in YLI have identified and tackled significant problems in 
their communities. In 2012, YLI youth were in the midst of a project focused on gambling addiction among young people. That year, a group of YLI members from a primarily Filipino neighborhood in Daly City conducted research in a casino. They initially were interested in finding ways in which young people, especially Filipinos, were being targeted by gambling establishments, but they stumbled onto a payday lending machine inside the casino which offered payday loans through pre-paid debit cards. ${ }^{255}$ Fahad Qurashi, a senior director at YLI who was in the casino with the YLI young people, reported:

The youth were flabbergasted. They were thinking, what is this thing? It's not an ATM, that's for sure. There was a bad feeling to it. It just felt like something was up with this. This doesn't seem right. There wasn't even human interaction in order to get that money fronted. ${ }^{256}$

Motivated by their encounter with the novel machine, members of YLI became interested in launching a campaign to learn more about payday loans and their connection to problem gambling. After an unsuccessful effort to pull together a grant application to SVCF in 2012, YLI received a grant of $\$ 125,000$ in $2013 .{ }^{257}$ The purpose of the grant was to "support youth-led advocacy efforts against payday lenders in Daly City and to train new youth leaders in La Honda/Pescadero and South San Francisco that will form part of a statewide anti-paydaylending coalition." 258 According to Qurashi, the grant was transformative for YLI inasmuch as the resources for a campaign would be available up front as opposed to the more typical situation of having to do a lot of work, put in a lot of time, and show accomplishments before getting any funding. YLI greatly appreciated the show of confidence by SVCF. ${ }^{259}$

\section{Organizing Model for Daly City and South San Francisco}

The organizing model was largely the same for Daly City and South San Francisco. First, young people would meet with experts on payday lending to become better informed. One such expert was Tim Lohrentz of the Insight Center, who had recently prepared two important documents. In March 2013, Lohrentz published an analysis of the net economic impact of the payday lending industry in the United States, where he concluded that despite the economic benefits of the industry in terms of employee compensation, taxes paid, owner income, and the like, the overall national impact of the industry was a net loss of $\$ 774$ million and a net loss of

over fourteen thousand jobs. ${ }^{260} \mathrm{YLI}$ campaigners extrapolated that there was a roughly $\$ 50,000$ annual economic loss associated with each payday lender in Daly City.

In June 2013, Lohrentz published, Tools for Advocates of Limiting Payday Lending. ${ }^{261}$ The report, funded by SVCF, included a detailed comparison of census tracts in Daly City with and without payday lending establishments. ${ }^{262}$ The comparison revealed that the census tracts with lenders had lower incomes, education, and homeownership rates, and higher percentages of 
Hispanic/Latino residents than tracts with no payday lenders. Readers are meant to conclude that payday lenders target people with particular characteristics. ${ }^{263}$

Next, the YLI youth conducted their own observational assessment, making note of how many payday lenders existed in their community and where they were located. The youth also conducted a community survey in which they asked people whether they knew what a payday loan was, and if they did know, how much the loans cost. Respondents were also asked if they would support a city ordinance that restricted payday lending. Most of the approximately two hundred survey respondents were recruited on Mission Boulevard, the main corridor in which payday lenders are located and the area of Daly City where many of the YLI youth lived. The survey results were likely subject to interviewer bias, but the overall findings of general lack of knowledge of the payday loan product was consistent with other research on this topic. ${ }^{264}$ The survey also yielded a key lobbying tool: the claim that $80 \%$ of respondents supported increased regulation of payday lending.

In September 2013, YLI youth made their first appearance before the City Council. They took only two minutes of the Council's time, but submitted their economic impact analysis and survey research results. They also asked for the city to implement an ordinance that would stop payday lenders from opening within a one-mile radius of schools and low-income communities. $^{265}$

In October 2013, shortly after YLI's appearance before the city council in Daly City, an event took place that helped spread the anti-payday activism beyond Daly City. It was the launch of the School for Financial and Economic Justice. The purpose of this three-day class was to convene and train youth leaders from across San Mateo County. By emphasizing the history of predatory and discriminatory financial practices, the presenters aimed at agitating the students enough that they would want to fight for reforms. To that end, the school emphasized a trainthe-trainer model whereby participants would be able to transmit not only their knowledge but also their passion to other young people. ${ }^{266}$ Several of the youth trainers were from Daly City, where they had already gained some experience and media attention. ${ }^{267}$ There was also a group of students from the nearby city of South San Francisco who knew some of the young people from Daly City. According to Qurashi, the youth from South San Francisco came to the training because their friends in Daly City told them there was going to be food and the opportunity to stay for free in a hotel for two nights, away from parents. While many of the attendees may have attended for "some good pizza," Qurashi recalled, they left the school "super-hungry" for social change because they and their families are the ones most affected by predatory lending. ${ }^{268}$

\section{Daly City Political Dynamics}


Back in Daly City, YLI met with city officials to advance the idea of an ordinance. They arranged meetings not only with the five city councilmembers (one of whom served as mayor) but also with the city attorney and the city manager. The $\mathrm{YLI}$ youth came to these meetings ready to discuss the economic impact study and the community survey. The economic analysis was particularly important when lobbying the city manager, who, according to Qurashi, holds a lot of power in small cities such as Daly City. ${ }^{269}$ Nevertheless, it is the city council that makes the final decision on whether an ordinance will be enacted, and the dynamics on the council were complex. The main issue was who on the council would be the ordinance's main champion and therefore get credit for its passage.

Councilmember David Canepa had introduced the legislation in May 2011 to ban permanently any new payday loan companies from specified areas in Daly City and set minimum distances between each lender. ${ }^{270}$ His proposed ordinance also called for a partnership between Daly City and local credit unions to offer short-term loans at interest rates far below those charged by payday lenders. Canepa reported that pushback from payday industry lobbyists was almost immediate. ${ }^{271}$ The city's planning commission supported the proposed restrictions, but without any effort by Canepa to mobilize citizens, the ordinance was not enacted by the city council.

When it came time in $\mathbf{2 0 1 4}$ for YLI youth to identify a member of the city council to champion a payday ordinance, they were faced with a difficult choice. Canepa was mayor at the time and appeared to have better access to the media, but the youth felt that another councilmember, Mike Guingona, was more likely than Canepa to work with youth as equal partners. ${ }^{272}$ The young people opted for Guingona, a choice that annoyed Canepa and exacerbated a budding rivalry between Guingona and Canepa, both of whom, according to Qurashi, had their eyes on a seat on the San Mateo County Board of Supervisors. ${ }^{273}$ Not choosing Canepa created a danger that he would quash the policy or at least proceed without involving or acknowledging YLI.

Guingona coached the members of YLI about meeting with his fellow councilmembers. He told them:

Have a meeting with every single one of the council members on your own without me. And do what we do. ... Start counting votes. At the end of your meeting with these people you have to say, "Will you support it?" And they have to tell you yes or no, because when you get in front of them in public, you're going to reference a prior discussion that you had with them in public. ${ }^{274}$

Guingona cautioned the young people not to use his support of an ordinance as a talking point in their favor. He said that the Council is politically divided, so they needed to line up at least two other supporters before he would exercise inside leadership. Until then, he provided 
strong but quiet mentoring to $\mathrm{YLI}$, especially on how to counter arguments that an ordinance was unnecessary or should be a matter of state or federal action. ${ }^{275}$

The prospect for an ordinance improved markedly in June 2014 when the city's Planning Commission voted 5-0 to forward a proposal to the City Council with a recommendation for approval. The ordinance was modest. It would require a one thousand foot minimum distance between new payday lending establishments and existing ones. ${ }^{276}$

Along with Qurashi, the youth members of YLI turned out in force at the July 14, 2014 public hearing for the ordinance. The YLI contingent dressed nicely for the occasion. Qurashi, wearing a suit, introduced himself to another well-dressed gentleman who turned out to be a lobbyist for the payday industry. By the time the hearing began, the gentleman was gone, which Qurashi attributes in part to the vibrant presence of the youth. In addition to Qurashi, eight members of YLI's youth addressed the City Council.

An additional ordinance supporter, Jessica Martinez-Escobar of the California Reinvestment Coalition, urged the Council to strengthen the ordinance further by requiring a conditional use permit for new establishments and increasing the locational separation to 1,320 feet. ${ }^{277}$ Appropriately for a story that started in a casino, Councilmember Sal Torres saw the 1,320 feet increase and raised it to 2,000. ${ }^{278}$ After review by the city attorney, the ordinance requiring a 2,000 foot buffer between lending establishments passed unanimously at the August 11 meeting of the City Council. ${ }^{279}$ This became one of the strongest distance restrictions in California. In navigating the tension between councilmembers Canepa and Guingona, the youth learned valuable lessons about politics because the support of both men was likely needed to gain passage of the ordinance.

\section{Spillover to South San Francisco}

YLI youth from South San Francisco attended the crucial July City Council meeting in Daly City. According to Qurashi, "They were watching, they were examining, they were learning. And then in two months, they flipped it in South City." ${ }^{280}$ In other words, these youth took the lessons learned in Daly City and succeeded in convincing the South San Francisco City Council to pass a similar ordinance on October 22, 2014. The victory was tempered in two respects, however. First, YLI's members were disappointed that the distance requirement was only a thousand feet compared to two thousand in Daly City. ${ }^{281}$ Second, YLI youth got the impression that the motivation for the ordinance was less about protecting low-income citizens from predatory lending practices than it was about making South San Francisco attractive to hightech companies and their employees. ${ }^{282}$ Despite that, the South San Francisco ordinance limited the hours of operation of payday lending establishments to 7 a.m. until 7 p.m., something the Daly City ordinance did not include. ${ }^{283}$ 
The experiences of Daly City and South San Francisco demonstrate that a youth organization can, with adequate funding and involvement from SVCF, make an enormous difference in passing political reforms. Perhaps equally important, organizations like YLI can transform the lives of at-risk youth and turn them into community activists and leaders, all while also changing the law for the rest of society. When interviewing Qurashi, we asked whether the most troubled youth were simply not up for the challenge of organizing. He responded that those were the very youth that YLI sought to engage, retain, and, ultimately, transform. ${ }^{284}$

\section{The Work Continues}

As of October, 2016, sixteen zoning-type moratoria or ordinances had been passed in the two counties comprising Silicon Valley. In 2015, CAPP's efforts in Santa Clara County were rewarded with new ordinances in Campbell and Morgan Hill. In 2016, CAPP helped secure a moratorium in Cupertino and is currently seeking a permanent ordinance. In San Mateo County, the Youth Leadership Institute (YLI) and Community Legal Services of East Palo Alto are currently working toward ordinances in Pacifica and Half Moon Bay. The timeline below summarizes ordinances in Silicon Valley.

Figure 5: Timeline of Silicon Valley Payday Ordinances

\section{Silicon Valley Ordinance Timeline}

\section{6: Cupertino*}

\section{5: Campbell, Morgan Hill, San Mateo City}

2014: Daly City, Gilroy, South San Francisco

2013: Sunnyvale

2012: Los Altos, Menlo Park,** San Jose, San Mateo County, Santa Clara County

2011: East Palo Alto, Redwood City

\section{9: Pacifica***}

*Moratorium Currently In Place

***Moratorium Became Ban in 2014

*** Moratorium Expired in 2011 
Several SVCF grantees have taken lessons learned in Silicon Valley to other California cities. Most notably, the California Reinvestment Coalition and YLI have helped enact ordinances in Long Beach (2013) and Fresno (2014), respectively. In Berkeley, the Planning Commission has been considering a payday ordinance based on the San Jose model. ${ }^{285}$

SVCF's advocacy on payday lending has also made an impact at the national level, by leveraging their network of community foundations across the country to join together in urging the Consumer Financial Protection Bureau (CFPB) to adopt tougher standards to curb harmful payday lending practices. Erica Wood, SVCF's chief community impact officer, emphasized the important role community foundations can play in advocacy work. "Issues like payday lending that greatly impact our communities require a multi-faceted approach to create lasting change. We can't just rely on funding. We have to be actively pursuing public policy advocacy efforts at the local, state and national levels." ${ }^{286}$ 


\section{The Metropolitan Dallas Experience: Passion, Perseverance, and Collaboration}

\section{Introduction to Dallas-Area Campaigns}

Beginning in the mid-2000s, Texas became a hotbed of payday lending activity. According to Ann Baddour of Texas Appleseed, a nonprofit organization devoted to social and economic justice, in 2004 most payday lenders were operating with the "rent-a-bank" model-licensed by the state, but evading state usury laws. After 2004, they all migrated to the CSO model (described further below) due to FDIC rules limiting consumer indebtedness to payday loans offered by banks. According to Texas state records, using this CSO model, payday loan stores increased from 1,303 in 2004 to about three thousand in $2011 .^{287}$

By 2008 , Texas was becoming a hotbed of local anti-payday lending ordinances as well. ${ }^{288}$ Religious congregations, charities, and other nonprofits in Texas saw an uptick in requests for financial assistance (or "benevolence") from consumers who could not pay both their payday loans and their regular monthly expenses. This galvanized religious groups and nonprofits to organize into a diverse coalition and take strong unified action to curb payday loan abuses.

As in Salt Lake County and the San Francisco Bay Area, efforts in the Dallas area to enact payday loan ordinances were spurred by a perceived lack of meaningful state or federal regulation to address a growing social problem. As one interviewee explained, the community needed to act locally because the industry's lobbying money was "too concentrated at the state level. At the local level, you can cut through that."289

The first local payday loan ordinances in Texas were zoning ordinances like those in California and Utah, but in 2011, the city of Dallas passed a substantive regulation that limited the terms of these loans. ${ }^{290}$ Among other provisions, the ordinance capped the number of times a loan could be renewed or paid in installment, and it required that the proceeds of any renewal payment reduce the original loan principal by at least $25 \%$. Ignited by the action in Dallas, similar substantive regulations spread like wildfire all over Texas. In 2012, three cities including Dallas had passed these substantive regulatory ordinances. ${ }^{291}$ By mid-2016, the number of cities with similar ordinances had jumped to thirty-five, the result of a grassroots social movement. $^{292}$ 
Figure 6: Time of Regulatory Payday Ordinances in State of Texas

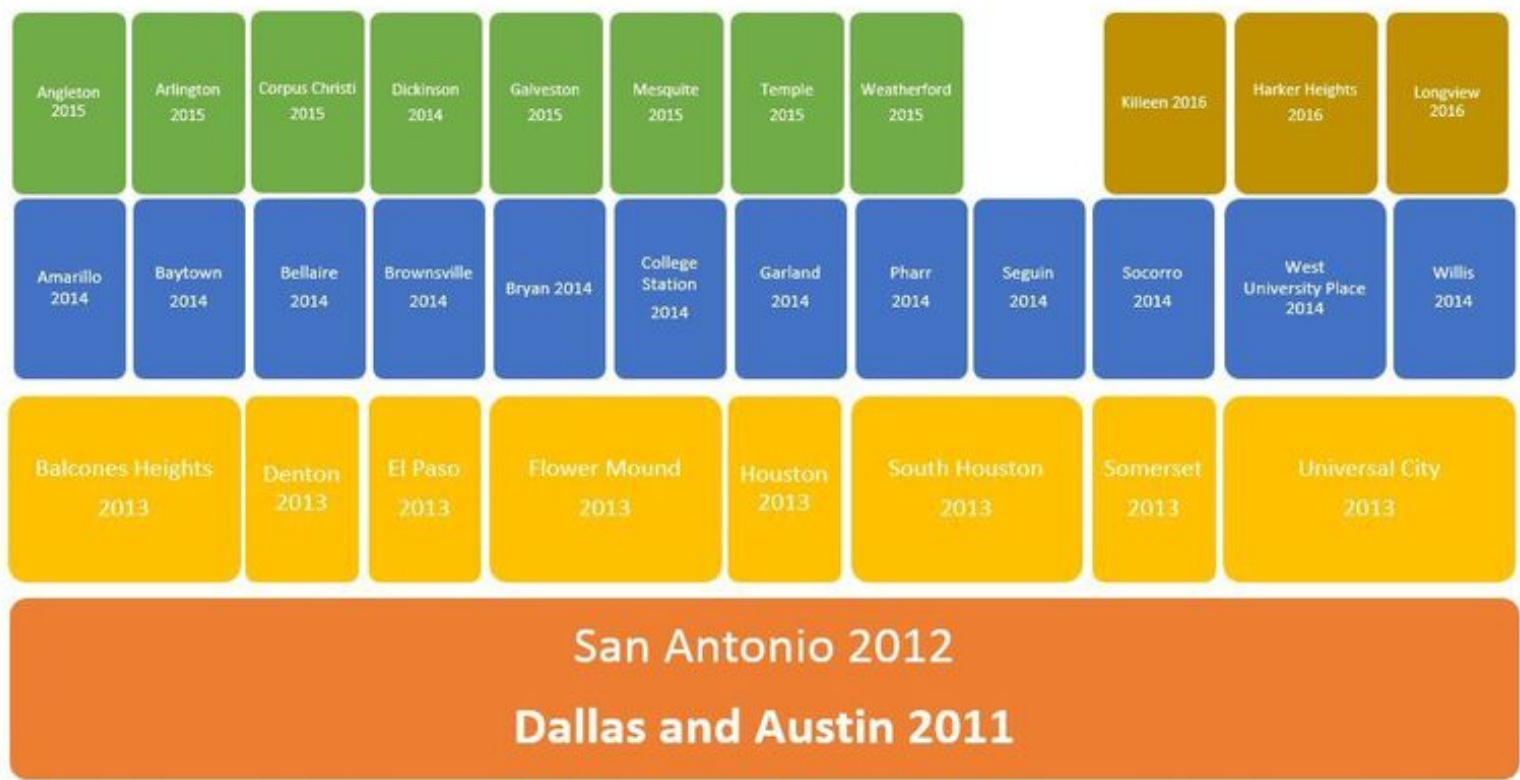

This movement, pictured in the Figure 6 above, demonstrates the power of a diverse coalition to pass a substantive ordinance and then spread it statewide.

\section{Barriers to Reform in the Dallas Metropolitan Area}

Local payday lending reform in the Dallas area faced some seemingly formidable barriers. The number of payday lenders was high, meaning any restrictions were likely to be resisted strongly. In addition, two of the state's (and nation's) largest payday lenders were headquartered in the Dallas region-ACE Cash Express in Irving and Cash America in Fort Worth. ${ }^{293}$ Their economic importance would likely translate into political clout.

As mentioned above, a change in the legal regime for payday lenders accounted for their large number and rapid growth in Texas after 2004. Prior to that year, many payday lenders in states, such as Texas, that had usury limits partnered with banks that were incorporated in states without interest rate limits. ${ }^{294}$ This "bank-charter" or "rent-a-bank" arrangement was roundly criticized by consumer advocates as a method of evading state-level lending restrictions, and the arrangement came under increasing scrutiny from Texas lawmakers and federal regulators such as the Federal Deposit Insurance Commission and the Office of the Comptroller of the Currency. ${ }^{295}$ In response, many payday lenders in Texas gravitated to a new 
business model, one that that allowed lenders to suddenly lend on any basis they liked, without legal oversight, under a loophole to the state's $10 \%$ usury cap. ${ }^{296}$

The loophole derived from the ability of a payday lender to register as a Credit Service Organization (CSO) under Texas law. ${ }^{297}$ CSOs receive payment for brokering the extension of credit between a borrower and a lending institution. While the lender itself is subject to the $10 \%$ interest rate limit, the CSO is providing a brokering service, not offering a loan, and can charge any fee it chooses. Once the CSO model was declared legal in 2004 by the Fifth Circuit Court of Appeals in the case of Lovick v. Ritemoney Ltd., payday lenders gravitated to it. A proindustry website proclaimed: "An important aspect of the CSO or Credit Services Organization model is that there IS NO LICENSING required by the state! CSO's are required to "REGISTER" with the Secretary of State, they are NOT licensed, AND THEIR FEES ARE NOT REGULATED."298

\section{Unique Opportunities for Reform in Texas}

Whereas the CSO model enabled the payday lending industry to flourish in Texas, it also created an opening at the local level for payday lending's opponents. Cities and other local jurisdictions were preempted from regulating the lending practices of the companies that supplied the funds for payday loans, but localities retained the right to set rules for the CSOs. Moreover, these rules could go beyond zoning, as in Utah, and address the features of the services provided by CSOs, such as the loan amount, the number of loan rollovers, and the terms under which the loan can be repaid.

The enormous opportunity for limiting payday lending provided by the CSO model was amplified by various aspects of Texas legal, political, and religious culture. First, Texas is a "home rule" state. Under the home rule contained in the Texas constitution, municipalities with more than 5,000 residents possess "the full power of self-government" and must look to the state legislature, not for grants of power, but only for limitations on their powers. ${ }^{299}$ The legislature can limit the broad powers of home-rule cities only explicitly and with unmistakable clarity. This leaves municipalities in Texas with expansive power to enact local laws and makes it unlikely that their actions will be preempted by state lawmakers. ${ }^{300}$

Second, Texas has a strongly populist spirit that disdains big government and holds that Washington, DC and Austin should stay out of local affairs. This populism crosses the political spectrum. For example, progressive activist Jim Hightower and conservative ex-governor Rick Perry both call themselves populists. ${ }^{301}$ Whereas home rule permits localities to control payday lending, populism supports it.

Third, religiosity runs deep in Texas and, in the case of payday lending, helped spur reform. Whether the Texans interviewed for this study were Catholic, Baptist, Non-denominational, 
Evangelical, or Jewish, they were uniformly passionate about their faiths and the obligations that flowed from them to promote social justice. In the predominantly Black churches of Dallas, social justice played a prominent role in church life, to the point where some churches had specialized social justice ministers. Danielle Ayers, who serves as Minister of Justice at Friendship-West Church in located south of downtown Dallas, explained that the Black churches have always been an important catalyst for social change, both nationally and in Texas. In an episode described more fully below, Reverend Gerald Britt, former Senior Pastor for the New Mount Moriah Missionary Baptist Church in South Dallas and a vice president of the Dallas nonprofit CitySquare at the time of the payday ordinance campaign there, was able to get a large number of people to sign a petition in support of a payday loan ordinance as they left a multi-church rally. ${ }^{302}$

The idea that faith should drive political action extended beyond the Baptist churches of South Dallas. Members of interfaith organizations such as the Dallas Industrial Areas Foundation (IAF) felt that tackling a social issue through faith would lead to greater faith development. ${ }^{303}$ Other faith leaders felt that tackling social issues was a way for a religious organization to stay relevant with all parishioners but particularly with millennials looking for reasons to stay affiliated with formal religious organizations. Some religious leaders were bothered by inaction in the churches in which they grew up and wanted to fight hypocrisy with action, to actually do something and not just talk about rewards in heaven. ${ }^{304}$

The social justice implications of faith and justice not only crossed religious congregations and denominations; it brought these congregations together as well. For example, Wilshire Baptist, a relatively wealthy Baptist church in a predominantly White North Dallas suburb, teamed with a Baptist church in predominantly Black South Dallas, Friendship West, to form a strong multiracial partnership to address social issues and inequalities, including payday lending. Inclusive religious coalitions also made it possible for the Jewish community to take a stand against payday lending, even though the issue was one that had little everyday relevance to many of its relatively affluent members. The breadth and depth of coordination among different religions and ethnic groups in combatting payday lending was unique to the Texas experience in our study and chipped away at historical racial and economic divides such as those between North Dallas and South Dallas. ${ }^{305}$

Religiously-based opposition to payday lending had the further advantage of being viewed by the campaign participants as being non-political and non-partisan. Several interviewees felt it was important to mention that they were political conservatives, a philosophy not typically associated with government control of business practices. Furthermore, some interviewees flinched at being called "activists," a term often associated with liberal social causes. Walker 
Moore, an organizer for Dallas Area Interfaith, said: "We are not activists. We are engaging with a congregational member who is anti-this, but he's part of a religious institution, and his opposition is part of his faith development. If we're in a Catholic Church, its development of Catholic faith. If it's a Jewish synagogue, it's their Jewish faith." ${ }^{306}$

Ann Baddour of Texas Appleseed, also frames opposition to payday lending in completely apolitical terms:

I wouldn't say we were activists in the traditional sense of the word. This was a real community-based call for help. The nonprofits were seeing their investments in the community drained. Pastors were seeing this as both a moral and a bottom line issue for their communities and were speaking up. That's what was really driving the cause-problems that were very real to the organizations in the community as well as individuals. The word "activist" can lead to connotations that make it seem like, "Oh, people were just out to do something." This was really driven by, bottom line, very real impacts in the community and people trying to find a way to address a problem. $^{307}$

Whether by virtue of payday lending's relationship to faith development or the everyday problems of communities, the ability to present the issue as non-political helped support local reform efforts.

The remainder of this Dallas section describes chronologically the events leading up to the passage of the various Dallas ordinances, including coalition building, the inside work of Dallas City Councilmember Jerry Allen, and the role of the media. This discussion is followed by a description of how the Dallas ordinance spread throughout the state, highlighted by one example from Denton, Texas. This Dallas section ends with a brief discussion of the strategies used by advocates and industry.

\section{Components of the Dallas Area Payday Loan Ordinance Movement}

When people are asked how the local anti-payday lending movement got started in Texas, most people consider Ann Baddour of Texas Appleseed to be the key person. Baddour began working at Texas Appleseed in 1998. Payday lending first came to her attention in the early 2000s. By the mid-2000s, payday and auto title lending had moved up Texas Appleseed's issue agenda due to the rapid increase in payday lending in the state associated with the new CSO model. ${ }^{308}$ 
Baddour's enduring contribution was seeing the possibility of moving beyond zoning as a means of controlling payday lending. This insight emerged from research Baddour supervised by a student in the Entrepreneurship and Community Development Clinic at the University of Texas School of Law. She and the clinic student concluded that Texas city councils had more power to regulate substantively than most local governments nationally. Baddour shared these findings with city council members around the state. No one showed much initial interest in using their local powers to regulate payday lending, that is, until Baddour spoke with Councilman Jerry Allen of the Dallas City Council in early 2011. Teaming with a coalition of community organizations, Allen would be instrumental in passing Dallas' landmark payday lending ordinance.

\section{Champion within the Dallas City Council: Jerry Allen}

To get a local payday loan ordinance passed, there must be leadership within city government. If no one in City Hall is interested, nothing will happen no matter how much local groups build support. As Ann Baddour explained, "I can have as many good ideas as I want, but if there is not someone who has the capacity to implement it, then it will never happen." ${ }^{309}$ Jerry Allen played that role in Dallas.

Before being elected to the Dallas City Council, Allen made his career in the banking industry. $\mathrm{He}$ is a self-described conservative who wanted people to know that the payday ordinance movement was not created by "a "bunch of crazy liberals." ${ }^{310}$ Allen had a long-standing interest, however, in helping bridge the gap between the rich and the poor. He grew up in the same Dallas neighborhood he represented on the City Council, an area with pockets of poverty. Many of his actions on the Council were directed at alleviating this poverty in his district.

Sixty-three percent of his district lived in a series of aging multi-family dwellings, which could have been torn down, but rather than push for that, he did what he could to reduce crime and improve education for the area's residents. As a former banker, Allen was especially interested in a program called Bank on Dallas that increases financial literacy, promotes traditional banks as an alternative to payday lenders, and boosts savings rates.

Allen looked forward to a press conference scheduled for the afternoon of June 16, 2010 to publicize the new program, but a morning event stole the media's attention. The Dallas City Council presented an award to the payday lender ACE Cash Express for providing humanitarian aid via the Red Cross to earthquake victims in Haiti. ${ }^{311}$ According to the press release of the event, the $\$ 106,000$ in relief funding had come from donations provided by ACE's customers. For an opponent of payday lending, it might have been hard to take the statement by ACE's 
President and CEO that the company was "dedicated to giving back to society," but even harder to swallow was the proclamation by the City of Dallas praising ACE's community outreach efforts.

The press attention devoted to ACE Cash Express's donation and award diverted attention from Allen's Bank on Dallas celebration, which galvanized Allen to fight payday lending. As Councilman Allen recalled:

When I was doing my Bank On program, of course it's all about the media. We were going to have a big kickoff at City Hall for the Bank on Dallas program-big kickoff, huge kickoff-and the day before the kickoff, I get a call from a lobbyist who wanted me to meet with the ACE check cashing people in the morning, and I said I could not because we were having a Bank on Dallas celebration.

Well, this is the day I'm having my kickoff at City Hall in the flag room. The mayor's going to be there and all these folks have been working six months to put this together, and suddenly that morning, the City of Dallas is giving a proclamation to ACE for being an outstanding corporate citizen.

At that point in time, it was pretty much game on. You gonna pull that on me, you gonna do that? Well, then, well guess what? It's show time. You know, we'll take you on now. And that's really what set the tone. When you pull that, when you pull that, it was show time." ${ }^{312}$

Thus, the clash of events on June 16 became the galvanizing force behind Jerry Allen's passionate fight for payday loan reform. ${ }^{313}$

\section{Building a Coalition}

Jerry Allen's decision in mid-2010 to use his position on the city council to fight the payday lending industry took place against a backdrop of growing pressure for reform. A few years earlier, several cities in the Dallas metropolitan area had used their zoning powers to limit the growth of payday lenders in their communities. In April, 2009, Texas Appleseed released a survey of Texas payday borrowers and made several policy recommendations, although passing local ordinances was not one of them. ${ }^{314}$ A year later, AARP Texas, along with the Texas NAACP and the Austin-based Center for Public Policy Priorities, had launched a campaign based on the theme that "500\% Interest is Wrong." ${ }^{315}$ Also during the 2009-2010 period, newspapers in Texas, including the Dallas Morning News, ran stories on the payday industry. ${ }^{316}$ 
What Jerry Allen lacked, however, was a local partner who could mobilize grassroots support for an ordinance and thereby add legitimacy to his cause. Allen's partner emerged in the fall of 2010 in the form of the Anti-Poverty Collation of Dallas (APC). The coalition described its goal as moving 250,000 people out of poverty permanently by 2010 "by coordinating efforts to keep people from falling into poverty and increasing pathways out of poverty. We are a broad-based coalition that unites the business community, faith-based organizations, social service agencies, and foundations." ${ }^{317}$ The APC did most of the heavy lifting in organizing community support around the Dallas ordinances. Long-time community organizer and community leader Reverend Gerald Britt described this particular coalition as the "longest lasting, most nimble coalition that I've been a part of when it comes to addressing issues of poverty."

\section{Pre-Coalition Organizing}

The coalition started through the efforts of the Dallas area AARP, which began focusing on payday loan advocacy in 2009 after its leaders were startled to see storefronts popping up everywhere. ${ }^{319}$ The AARP regularly educates members on financial security, financial resiliency, and related health issues, and its leaders began hearing stories about members who were facing financial difficulty after taking out the loans. Additionally, a survey of nonprofit clients conducted in collaboration with multiple partners and analyzed by Texas Appleseed showed that one in five payday lending customers was over fifty. ${ }^{320}$ As a result, while continuing to work on other financial security issues, AARP began working closely with Texas Appleseed for statewide reforms. AARP began doing polling, creating videos, and helping to organize and get borrower stories behind the scene. ${ }^{321}$

In late 2009 and early 2010, religious groups around Dallas began hearing about the AARP's involvement in payday lending education and advocacy and themselves began thinking about payday lending in the context of overall poverty alleviation strategies. ${ }^{322}$ Religious organizations initially got involved when people came to them and said, "I need help paying my utility bill." The church would help them but then realized that the money they were providing was really going to a payday lender who would have gone unpaid otherwise. Similarly, social service grantees of the United Way realized that by helping people with bills, they were really just helping them to pay their payday lenders. As Stephanie Mace further explained:

A lot of our basic needs service providers have limitations on what they can pay off for their clients. And so, it's usually limited to utilities, mortgage, things like that. So, that is how they're able to help a family meet their monthly expenses. The Texas Catholic Conference actually did a survey of non-profits that provide financial 
assistance to individuals. They found that 32 or $33 \%$ of the clients needing financial assistance actually have a payday loan too. ${ }^{323}$

\section{Founding the Anti-Poverty Coalition}

In mid-2010, these religious groups, along with the United Way and other nonprofits, held several community meetings to brainstorm about solutions. In the fall, the Jewish Community Relations Council (JCRC), CitySquare, and the Dallas area United Way founded the Anti-Poverty Coalition of Greater Dallas and began holding meetings with other organizations across the Dallas metro area to discuss general poverty alleviation strategies. ${ }^{324}$ The AARP was not a member of this coalition but did help organize meetings. As explained by Susan Williams of the AARP, her organization along with JCRC, CitySquare, and the United Way, set up the initial meeting with this strategy in mind:

Rather than us determining the priority, what we really wanted to do was to invite foundations, invite nonprofits, invite faith organizations, invite everybody to come together and for the attendees to really determine the priorities of the coalition. And that was where payday and auto title lending and financial education really rose to the top. $^{325}$

The resulting group of attendees, which totaled forty to fifty people from all across the community, held several meetings which included breakout sessions in which participants brainstormed about poverty and barriers to alleviating it. In September or October of 2010, using anonymous clickers to set priorities, the group placed reform of payday lending at the top of their issue agenda. ${ }^{326}$

This outcome reflected the fact that the members of the coalition were seeing problems among congregants and clients associated with the loans but were unsure what to do about these loans. As Marc Jacobsen, formerly of the JCRC, explained: "They are service agencies, not advocates, so they didn't see what their role was going to be or how to take it on themselves." ${ }^{327}$ The APC's response was to create a fair lending campaign sub-committee to address payday lending. The members of the sub-committee included AARP Texas, Catholic Charities of Dallas, Inc., CitySquare, Friendship-West Baptist Church, Jewish Community Relations Council of Greater Dallas, Literacy Instruction for Texas, United Way of Metropolitan Dallas, National Council of Jewish Women (Greater Dallas Section), Texas Baptist Community Development, Prestige Community Credit Union, and the Urban League of Greater Dallas and North Central Texas. 


\section{Religious Involvement in the Coalition}

The faith-based community played a far larger organizational role in the local anti-payday loan movement in greater Dallas than in either Northern California or Salt Lake City. Their participants spanned different religions, races, and social classes. Most of the major religions in the Dallas area were represented in the coalition, although a few played more prominent roles than others. Some of the key figures are described below.

\section{Reverend Gerald Britt of CitySquare}

Reverend Gerald Britt, a Baptist minister and vice president of the anti-poverty organization CitySquare, became the de facto figurehead for the Anti-Poverty Coalition. He explained his introduction to payday lending as follows:

I met with an individual who suggested that I read a book called Broke, USA by Gary Rivlin, and I read the book. At that time, I was writing a column for the Dallas Morning News. We ran a column on payday lending, after which we actually reviewed the book in our monthly book review. From there, I was introduced to Stephen Reeves, who at that time was [legislative counsel] at General Baptist Convention. Then [I] just kind of got involved from that point in trying to do what we could at least in CitySquare's role, just being an advocate for getting people to watch out on payday lending. We were dealing with for-profit colleges and payday lending and a few other issues that, you know, just helped keep poor neighborhoods poor, so this was one of them. ${ }^{328}$

Describing the difficulty of gaining public support for payday loan regulation, Britt explained:

We were accused of being anti-business and anti-capitalist and all this other kind of stuff. [We are told that borrowers are] ne'er-do-wells who were taking out these loans were unable to pay them back or whatnot, and that was really the climate. It took some persistent work to change the conversation when people actually got to realize that this was a problem. ${ }^{329}$

Reverend Britt contributed to the campaign to enact local payday ordinances in several ways. He helped lead the Anti-Poverty Coalition, contributed guest columns about payday lending to the Dallas Morning News, and blogged about the industry and its practices. He was also instrumental in generating petition signatures in support of the Dallas ordinance. In late 2010, Reverend Britt helped lead a large revival meeting dedicated to social justice issues. The revival 
drew participants from about fifteen churches and took place in a church accommodating nine hundred people. According to Britt, "The church was packed, and the last night of the revival, we stationed people at each of the exits with petitions for people to sign. The hallways leading to those exits were so clogged with people signing the petition that mayoral candidate Mike

Rawlins couldn't get out." ${ }^{330}$ Several months later, the petition was presented to the Dallas City Council with nearly four thousand signatures. ${ }^{331}$

\section{Danielle Ayers of Friendship-West Baptist Church}

Within a short time after the original founders of the coalition began meeting, Danielle Ayers, the Minister of Justice of Friendship-West Baptist Church, became a pivotal figure in the coalition and the movement. ${ }^{332}$ She was already doing community outreach with her congregants around payday lending after seeing congregants unable to pay back their loans and meet regular expenses. ${ }^{333}$ The church's head pastor, Reverend Fredrick Hayes, even began educating people about payday lending from the pulpit. ${ }^{334}$

Friendship-West eventually prioritized payday lending as a major social issue. Ayers explained the process by which her church decided to get involved in the issue of payday lending:

Unfortunately, in the African-American community-because we have so many multi-layered issues-we can't say, "We'll deal with debt later." Because it's just as critically important as the other issues and they are all interconnected. So we just try to manage the process and connect the dots. I'll sit down and talk with Dr. Haynes and say, "What do you feel is best? How do you want to handle this? Do you want to lead because we feel so strongly about payday lending or just support other organizations?" 335

Friendship-West decided to lead. In November, 2010, Ayers organized a huge march down Camp Wisdom Road, a large street with numerous payday and car title lenders that is close to Friendship-West and several other mostly-Black mega-churches. ${ }^{336}$ As Ayers explained when asked if it was common for churches to be involved in these social advocacy movements:

Prior to the interwar period between World War I and World War II, that was the black church. It was a justice-oriented and prophetic-oriented church. . . . We carried the prophetic tradition from slavery because we were always fighting against systems that oppress. So, it wasn't until Gayraud Wilmore [a theologian and historian of the AfricanAmerican religious experience] - who does an amazing job at laying this out - that some churches began to allow politicians to come in. And white folks started coming in and 
saying, "Not so loud, not so much." So, it then blossomed into what you have today. We are not monolithic at all. You have some black churches who would never talk about justice work. Theologically, they have a problem with it. ${ }^{337}$

Ayers noted that pursuing social justice is like long-distance running. She said: "When we talk about justice, it's not charity. It's not a one-time act. It's really trying to uproot systems that are broken. And that takes time." 338

When discussing how she organized the march down Camp Wisdom Road, Ayers noted that the people who came to march were not necessarily the ones who had taken out payday loans. She noted that there was shame and stigma associated with the loans, and borrowers were unsure what others would think if they knew a person had taken out one or more loans, especially if the borrower was an educated person like a teacher. Others might think:

"Oh, it's people who were mismanaging their money," or "They're trying to buy drugs." People don't think of the grandmother who is raising her grandchildren and trying to decide if she wants milk or medication, or a single mother, because, we know single women are the largest group of loan users. ${ }^{339}$

Ayers explained that the people who marched came because of their faith and to take a stand for those harmed. Including other area churches, 300-400 people marched. One payday lender actually came to Friendship-West and offered to pay off the existing loans of every person in the congregation if the church would stop "marching and making noise and advocating and trying to get the [CSO] loophole closed." ${ }^{340}$ Ayers said that the intention was not just to stop the march:

The idea was to stop the movement. To stop us from doing the advocacy work, going down to Austin, making noise, having Dr. Haynes stand up in the pulpit and talk about the issue. The church is not his only audience. The word goes out to thousands of people around the country and the world. ${ }^{341}$

Ayers and her church formed an anti-payday partnership with Katie Murray, the Christian advocacy specialist for Wilshire Baptist Church, a mostly White church in prosperous North Dallas. Murray described doing social justice work as a way to keep North Dallas youth engaged in the church and to grow the church's population at a time when more and more people are becoming unaffiliated. Ayers had different reasons: 
For us [in my church,] justice plays out whether the membership goes down or not. Katie's coming from a different socio-economic place than we are. Socio-economically, we are polar opposites, which is why I love working with Wilshire. ${ }^{342}$

Despite any differences in motivation, the two congregations and their leaders share a deep devotion to social justice. The congregations formalized a covenant in 2014 and have worked together since then to combat predatory lending. ${ }^{343}$

\section{The Catholic Church}

Although Catholic congregations and leaders did not play a big role with respect to the Dallas ordinance, they were central in the push for payday lending reform in nearby Arlington. Father Daniel Kelley of St. Joseph Catholic Church was particularly influential. In addition, the Texas Catholic Conference, the public policy voice of Texas' Catholic bishops, worked directly on payday lending reform at the state and local level, and also participated in Dallas Area Interfaith and Faith Leaders for Fair Lending. ${ }^{344}$ Hearing stories from borrowers who sought assistance from Catholic charitable organizations helped generate interest in the payday issue among Catholic leaders. ${ }^{345}$ The religion's long-standing antipathy to usury provided these leaders with a ready-made framework for opposing payday loans. ${ }^{346}$

Within the Dallas metropolitan area, the role of the Catholic Church was most notable with respect to the ordinance passed in Arlington in 2015. The political stakes were high there. Arlington is the seventh largest city in Texas, and prior to the passage of the 2015 ordinance, Arlington was the second largest city in Texas without a regulatory ordinance similar to the one passed in Dallas. ${ }^{347}$ Arlington is also home to one of the nation's largest payday lenders in the nation. Accordingly, industry opposition to an ordinance was strong. Rob Norcross, spokesman for the industry's trade association, Consumer Service Alliance of Texas, warned: "If they [the Arlington City Council] did something consistent with what the other cities have done, we would have to sue them." ${ }^{348}$ Nevertheless, through the strong leadership of Father Daniel (“Dan”) Kelley of Arlington's St. Joseph Catholic Church, the Texas Catholic Conference, and Dallas Area Interfaith (an arm of the Industrial Area Foundation), Arlington became the site of a strong and successful ordinance campaign. ${ }^{349}$

Beginning in 2015, Dallas Area Interfaith community organizers Josephine Lopez Paul and Walker Moore used the power of faith and conviction to build a coalition of Arlington-area community organizations to push for passage of a regulatory ordinance. Lopez Paul and Moore held listening sessions at St. Joseph's on the subject of payday loans, asking people if they had heard of them or knew people who had taken them out. At one of these sessions, they heard a 
story of a lady who had taken out a title loan. On a subsequent Sunday, they learned that the woman was not in church because her car was repossessed the previous Friday. Dallas Area Interfaith also held "civic academies" to educate people about payday lending. Based on what they had learned at listening sessions, civic academies, and other educational events, many parishioners e-mailed and called their representatives to support the regulatory ordinances. ${ }^{350}$

After the Arlington City Council unanimously passed a Dallas-style ordinance on November 17, 2015, about one hundred members of Arlington churches, community groups, and nonprofits organized by the North Texas Industrial Area Foundation, gathered outside City Hall to thank the council. Father Kelley addressed the crowd, lauding the Council for "standing up for our constituents by being the first city in Tarrant County to pass a payday loan ordinance." 351 Events in Arlington were emblematic of the role of religious organizations in passing payday ordinances.

\section{Supportive Mass Media in the Dallas Area}

In the Salt Lake City area and California's Silicon Valley, the largest circulation daily newspapers were supportive of efforts to enact local payday lending ordinances. Papers such as The Salt Lake Tribune and San Jose's The Mercury News did more than merely report on the activities of payday reform advocates and city council meetings. These newspapers also conducted unflattering studies of the payday industry and editorialized in favor of local ordinances. The same was true in Dallas but even more so. The Dallas Morning News-the largest circulation newspaper in Texas-not only covered the news; it helped make news in this instance.

As mentioned above, the Dallas Morning News invited Reverend Gerald Britt to regularly contribute opinion pieces that discussed payday loans. ${ }^{352}$ At the time the Dallas local ordinance movement was gaining steam in late 2010 and the first part of 2011, Reverend Britt wrote regularly about the issue. ${ }^{353}$ Britt's opinion pieces complemented the reporting being conducted by Jim Mitchell and other writers at the Dallas Morning News. ${ }^{354}$

It was the practice of The News to set annual priorities for the coming year's coverage. The paper chooses a few or a couple of major social issues and focuses on them for that entire year, trying to have real influence on the way that issues are handled in society. Given that most Americans are unaware of how payday loans work, this level of news coverage can make a huge difference in increasing awareness and, plausibly, getting ordinances passed. Many interviewees commented on the prominent role played by the Dallas Moring News, and reporter and editorial board member Jim Mitchell in particular. Other reporters such as Rudolph Bush also covered payday lending, as the issue crossed into several subjects covered 
separately by the paper, including business and economics, politics, and the North Dallas South Dallas racial and socio-economic divide.

\section{Industry Opponents in Texas}

The payday lending industry opposed both the zoning ordinances and business practice ordinances passed by Texas cities beginning in $2008 .{ }^{355}$ With respect to the Dallas ordinances, payday lenders were typically represented by their trade association, Consumer Service Alliance of Texas (CSAT). The trade association argued that their product served a legitimate consumer need and prevented consumers for paying even higher amounts for bounced checks. ${ }^{356}$ Rob Norcross, representing CSAT, commented that the Dallas ordinance "runs the risk of hurting people in Dallas by driving them to more expensive forms of consumer credit." ${ }^{357}$ In two studies released in August, 2010, CSAT argued that payday lending establishments neither contribute to crime nor lower property values. ${ }^{358}$

It took less than a month for CSAT to sue the city of Dallas over the ordinance. The trade association-later joined by two individual payday loan companies-argued that the city was preempted by Texas law from regulating the payday loan business. CSAT lost this suit at both the district court and appeals court levels. ${ }^{359}$ CSAT and/or individual lenders brought additional but unsuccessful lawsuits against the cities of Austin, Denton, El Paso, and San Antonio. ${ }^{360}$ As a general matter, the industry expended more resources seeking to overturn the municipal ordinances than trying to prevent them. Payday and auto title lenders saved their strongest lobbying efforts for the Texas legislature, where they achieved largely favorable results. ${ }^{361}$

\section{Passage of the Dallas Ordinances}

The city of Dallas passed two ordinances in 2011 that restricted payday lenders in quick succession. A zoning ordinance along the lines of ordinances passed previously in several Texas cities and in locales like Salt Lake City and Northern California was enacted unanimously on May 25. A more innovative ordinance controlling the practices of payday lenders passed on June 22 , again unanimously. This substantive regulatory ordinance restricted the amount that payday lenders can lend and required principal reduction if a loan is renewed. By mid-2016, over thirty Texas cities had followed suit by adopting the regulatory ordinances that closely followed the Dallas model, resulting in a "unified payday ordinance." 362 This section details how the political efforts played out over the roughly nine-months leading up to the passage of Dallas' two ordinances. 


\section{Early Coalition Action}

During the fall of 2010, the Anti-Poverty Coalition began a two-pronged approach to getting the Dallas City Council to act against payday lending. In terms of an inside political strategy, APC members began meeting informally with City Council members to discuss perceived abuses in payday lending. With respect to an outside political strategy of showing broad public support for reform, the Coalition participated in two important activities in November 2010. APC members helped organize an anti-payday lending march down Camp Wisdom Road in South Dallas, and they addressed a multi-church justice rally attended by nine hundred people.

The APC made its first foray into formal city council meetings in December, when several members of the Coalition addressed the City Council's Quality of Life Committee. This committee has a diffuse mandate, as reflected in subsequent expansions of its name: Quality of Life \& Government Services in 2011 and Quality of Life \& Environment in 2013. ${ }^{363}$ During its 2010-2011 meetings, the Committee discussed issues such as abandoned shopping carts, illegal dumping, animal services, trail safety, and library services. The Committee's meetings were sometimes cancelled due a lack of business and were rarely covered by the press, but the meeting held on December 13, 2010 provided the pro-ordinance forces the opportunity to gain some experience in presenting their views in public to city leaders in advance of more important meetings during the coming months.

At the Quality of Life Council Committee meeting, Gary Godsey, President and CEO of the United Way of Metropolitan Dallas; Tim Morstad, Associate Director of Advocacy of AARP Texas; Reverend Gerald Britt, Vice President of Public Policy \& Community Program Development; and Danielle Ayers, Minister of Social Justice at Friendship-West Baptist Church, described the high cost of payday loans as part of an information items on the agenda. The goal of the speakers was not only to urge passage of a local ordinance but also to pass a City Council resolution in favor of action at the state level to close the CSO "loophole" in Texas law that allowed payday lenders to charge so much. ${ }^{364}$ Councilmember Jerry Allen was not a member of the Committee, but he attended the meeting, presumably as a sign of support for payday reform. As the presentation was listed on the agenda as an information item, no action was taken by the Committee.

In January of 2011, ACP began having regular meetings. The minutes of the meetings on January 6 and February 17, attached as Exhibit B, show that twenty and sixteen people attended the meetings, respectively. Exhibit B also provides an idea of how ACP organized itself and the devotion of nearly all its attention to the payday lending issue. Indeed, the February minutes contained the following caveat: "There was some discussion about the need to keep in 
mind other issues for reducing poverty, including job creation and developing job skills, with the understanding that the payday lending and financial literacy focus is just the initial agenda items of the Coalition." 365

ACP was aware of the importance of messaging. During the course of the campaign, there was a gradual shift from being against "predatory" lending to being in favor of "fair" lending. Another element of message was to make sure that the problem of payday lending was not viewed as just about poor people. Rather, the APC stressed that everyone should care because it affects everyone. ${ }^{366}$ Walker Moore gave the example of a woman who worked for one of the banks that Dallas Area Interfaith used. At first, the woman said she did not know of anyone who had used a payday loan but then recalled that her daughter had. As Moore explained:

She's not an executive of this bank, but she works with the executives. And her daughter had just had to take out a payday loan for her car, which had some serious problems. After talking with me, this lady goes home and starts checking on what her daughter did because she knew what her daughter had done, but she didn't understand the ramifications. And so the woman from the bank started coming to our training sessions. And she immediately got that loan paid off for her daughter. She [ended up doing] all the behind the scenes organizing it takes to get the meetings set up because she saw what happened to her daughter. And this is a white lady, the nicest sweetest, lady in the world. I mean, she works for a bank. Her daughter is a schoolteacher. We're not talking about a low-income person barely scraping by. ${ }^{367}$

A final aspect of the Coalition's messaging was to address the payday industry's argument that regulation of loans was unwanted by payday borrowers and would leave them with no place to go to get loans that they desperately need. Reverend Britt countered that the industry talks about need but does not talk about how it "feeds the need." 368 In any case, advocates in the Dallas metropolitan area got way out in front of this common industry argument by originally defining their goal as: "Countering the problem of predatory lending by advocating for changes to public policy and promoting consumer-friendly lending alternatives" [emphasis added]. ${ }^{369}$ The Coalition also created a flyer for the first city council meeting that listed alternatives to payday loans, and APC repeated the message throughout the ordinance campaign that there were alternatives. ${ }^{370}$ 


\section{The Dallas City Policy Process Crests}

Once the Dallas APC organized, APC wanted to pass the strongest possible ordinance to curb payday lending. The rough plan was to pass a zoning ordinance to make a public stand on the payday issue and then wait to see if the state would substantively regulate payday loans in its regulatory session. If the state did not act, the plan was to follow the zoning ordinance with a substantive regulatory ordnance, which is exactly what ended up happening.

As in most cities, any potential change to the zoning laws is first reviewed by the planning commission. This was true in the case of Dallas, where the body's name is the City Plan [sic] Commission. Support for a zoning ordinance regarding "alternative financial establishments" did not come easily from the Commission. On January 11, 2011, a motion was initially made to deny creation of a new use category for alternative financial establishments. Before a vote could be taken, a substitute measure was proposed to take the matter under advisement until the next meeting in early February. ${ }^{371}$ Things went a bit better at the February meeting for ordinance supporters. A motion to create a new use category was passed unanimously, but a second motion to create minimum distance requirements between alternative financial establishments failed to pass. ${ }^{372}$

While using the city of Dallas's zoning authority to regulate payday lenders was moving slowly and timidly through the City Plan Commission, the City Council as a whole signaled its interest in the payday issue at its February 9, 2011 meeting. At the meeting, the Council unanimously passed a resolution calling on the state legislature to address problems associated with CSOs. ${ }^{373}$ Two weeks later, on February 22, City council member Jerry Allen appeared before the Senate Committee on Business \& Commerce and conveyed his city's resolution to the Texas Legislature. ${ }^{374}$ He also stressed that interest in payday reform reflected a "groundswell" and broad-based "movement." ${ }^{375}$ Allen mentioned the Bank on Dallas program as well as the likely consideration by the Dallas City Council of a thousand-foot separation requirement between establishments.

One other important city meeting took place during February, 2011. The City Council's Committee on Finance, Budget \& Audit met on February 28 and was briefed on the status of possible zoning changes pertinent to payday lending. Jerry Allen was the chair of the committee, so this meeting represented an opportunity to push forward the idea of a zoning ordinance, but the committee decided that it wanted to wait to see what action, if any, would be taken by the State Legislature before taking further action. ${ }^{376}$

The decision in February by the Dallas City Council's Committee on Finance, Budget \& Audit to delay action on payday lending reflected a realistic assessment of possible state-level reforms. A package of three bills was filed in early March with House Republican Vicki Truitt as their 
author. ${ }^{377}$ House bills 2592 and 2594 were fairly modest in scope. They required, respectively, certain disclosures to payday borrowers (technically, clients in the CSO model) and licensing of lenders (technically, credit service brokers). Both bills were embraced by Republican Senator John Carona and were eventually passed by the Legislature in June. A third bill, H.B. 2593, was more ambitious. It would have imposed restrictions on amounts, fees, renewals, and payment of payday and car title loans. It was H.B. 2593 that reflected the aspirations of people like Ann Baddour and Jerry Allen as well as the members APC. ${ }^{378}$

\section{April Activity}

On April 12, one day before the scheduled April meeting of the Dallas City Council, APC held an interfaith press conference about payday lending at City Hall. ${ }^{379}$ The press conference photo below shows, from left to right, Bishop J. Douglas Deshotel, Rabbi Adam Raskin, Minister Danielle Ayers, Reverend Gerald Britt, Dr. Fredrick Haynes, III, and Councilmember Jerry Allen.

\section{Figure 7: Leaders of Anti-Poverty Coalition Press Conference on April 12, 2011}

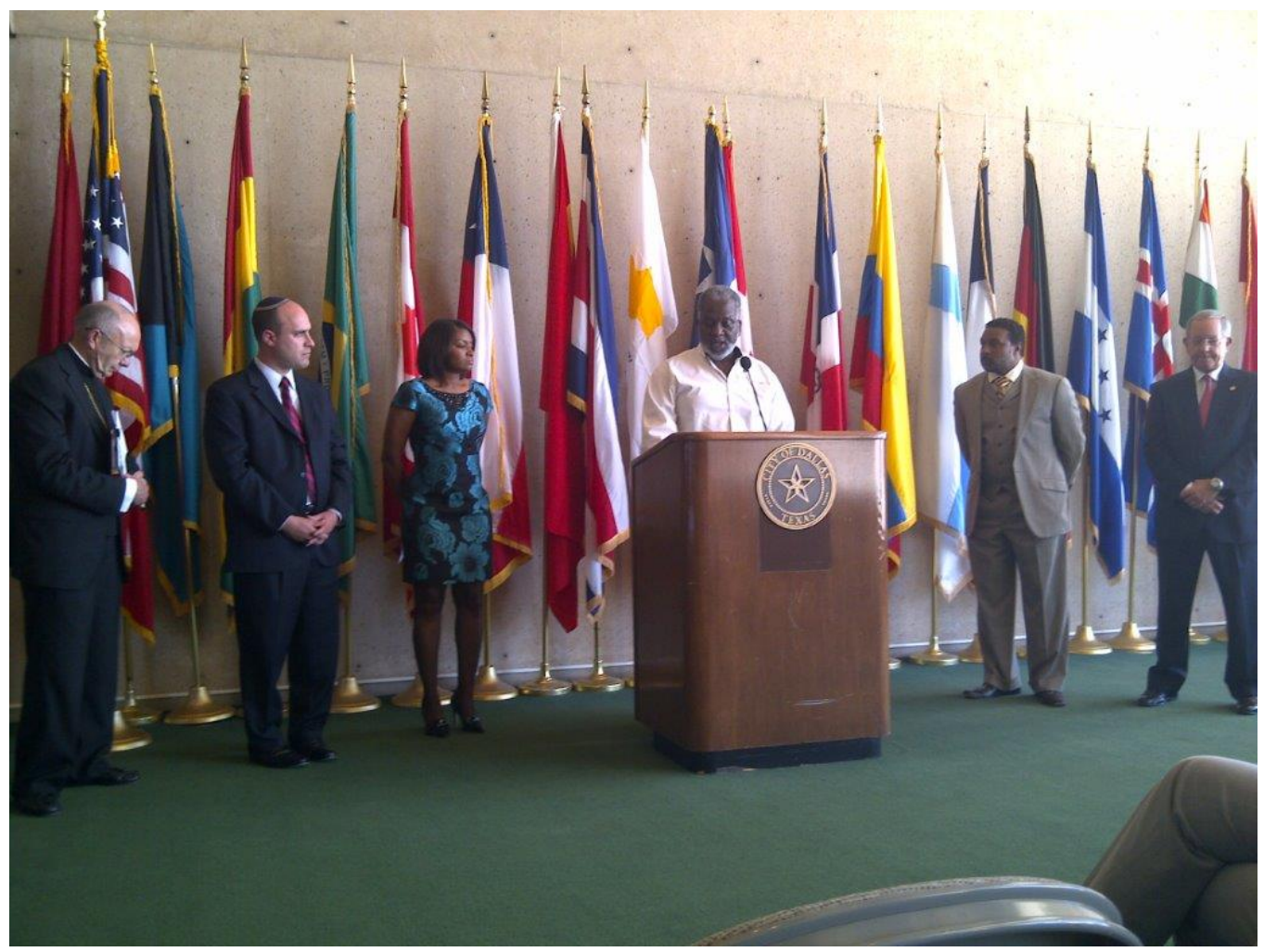

Photo courtesy of Stephanie Mace.

At the City Council meeting the next day, Reverend Britt spoke about payday lending during the public comment open mike period following the formal meeting. City councilmembers asked 
Reverend Britt a series of questions related to the availability of alternatives, the density of lenders throughout the city, the level of public support for regulation, and how the payday loan model traps borrowers. Britt was joined by two other notables in speaking for payday lending reform: Will McCall of the Dallas Leadership Foundation and Lisa Hembry of United Way of Metropolitan Dallas. ${ }^{380}$ Simultaneously, Jerry Allen worked behind the scenes to get Council support for payday loan reform. ${ }^{381}$

On April 25, the City Council's Budget, Finance \& Audit committee met to be briefed on the amendments to the city's development code that were being considered by the full City Council. $^{382}$ The Committee was chaired by Councilmember Allen, so it was not surprising that a motion was passed to move the draft ordinance onto the agenda of the Council's May $25^{\text {th }}$ meeting. At that point, the zoning ordinance would require alternative financial establishments (check cashing, payday, and auto title loan businesses) to be separated by at least five hundred feet and to obtain a special use permit. There was no discussion of an ordinance that would regulate the financial products themselves. ${ }^{383}$

An editorial in the Dallas Morning News on April $28^{\text {th }}$ bolstered the support that had been building all month for a payday zoning ordinance. The editorial called on the City Council to pass a zoning ordinance and the State Legislature to regulate the products offered by the full range of "alternative financial establishments." The editorial urged immediate action: "With deadlines looming in Austin and a new council taking office in June, this is a fleeting opportunity to rein in abuses inflicted on those who can least afford to take a financial hit." ${ }^{384}$

\section{May 25th City Council Meeting}

From the point of view of payday lending reform in Dallas, a potentially troubling event took place on May 14, 2011: Mike Rawlings was elected mayor. Rawlings, a former CEO of Pizza Hut, defeated several candidates. In April, outgoing Mayor Dwaine Caraway had blasted Rawlings as the "king of payday loans" by virtue of Rawlings' service on the board of directors of ACE Cash Express several years earlier. ${ }^{385}$ With Rawlings due to take office at the end of June, payday loan reform advocates realized that the clock was running. ${ }^{386}$

With respect to the zoning ordinance, the climactic meeting of the Dallas City Council took place on May $25^{\text {th }}$. Over two hundred community members attended the public hearing portion of the meeting to show their support for the zoning ordinance. Representatives of APC attended and brought detailed research notebooks with them, ready to answer any questions that might arise. Their "Fair Lending Campaign" binder (see its table of contents as Exhibit C) contained maps showing the location and density of payday lenders in Dallas, information on 
alternatives to payday loans, and letters of support from a variety of community organizations as well as two of the city's representatives in the Texas Legislature (Rep. Eric Johnson and Senator Royce West). ACP members also came prepared with over 4,000 signatures on petitions, postcards, and emails, favoring the zoning ordinances ${ }^{387}$ Inside the City Council chambers, APC members also wore the sticker shown below.

Figure 8: Anti-Poverty Coalition Lapel Stickers Worn at Dallas City Council Meeting

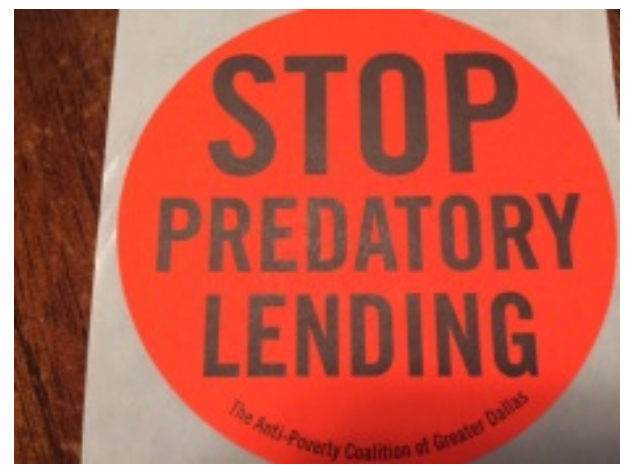

Courtesy of Stephanie Mace.

Four people in favor of the zoning ordinance addressed the City Council: Marie Graziano of AARP Texas, Rev. Frederick Haynes, III of Friendship-West Baptist Church, Rabbi Oren Hayonof the Rabbinic Association of Greater Dallas, and Rev. Gerald Britt of CitySquare and the AntiPoverty Coalition. ${ }^{388}$ No one spoke in opposition to the City Plan Commission's recommendation. ${ }^{389}$

Describing the overall ambience of the hearing, Marc Jacobsen explained:

At the city council meeting, Reverend Britt spoke, and Reverend Britt is a very powerful speaker. We had two hundred people there. A lot of them were from Friendship-West, but there were others as well. We had lots of people there from different communities. Perhaps this was overkill for the zoning ordinance, but it worked. The industry attended, two people, but did not speak.

When Reverend Britt spoke, the City Council could see that the entire room was standing (both literally and figuratively) with Reverend Britt and the other clergy present.

By the time of the public hearing, Jerry Allen had already spoken repeatedly to other members of the Council as well as the City Attorney. Allen also addressed the Council's fears of being sued over the ordinance. Before the hearing began, Allen knew that he had the votes to pass the ordinance. 
The final zoning ordinance was stronger than the one the City Council Budget, Finance \& Audit Committee had seen. Councilmember Allen amended the proposed ordinance as follows: increase the distance of separation between alternative financial establishments to 1,500 feet; require a minimum distance of 300 feet from a lot in a residential district and 500 feet from an expressway; and mandate that establishments be located in freestanding buildings. ${ }^{390}$ The City Council passed the amended ordinance unanimously.

All of this was happening at the same time as the state legislative session, at which many of the same advocates were also working. The members of the APC and Councilmember Allen deliberately pushed forward the zoning ordinance and waited on a possible ordinance covering payday loan products to see if the state legislature would make this second ordinance unnecessary by passing H.B. 2593. By late May, it became clear to the payday reform advocates in Dallas that only the more modest state bills would pass (H.B. 2592 and H.B. 2594). ${ }^{391}$ If payday lenders in Dallas were to be subject to stronger control than disclosure requirements, licensing, and zoning rules, the City Council would have to re-visit the issue.

\section{June 22 City Council Meeting}

In light of the State Legislature's action and inaction, Ann Baddour, Jerry Allen, and the Dallas City Attorney's Office drafted an ordinance that would regulate the features of payday loans (or, as described in the ordinance, "credit access businesses"). The ordinance was modeled loosely on failed House Bill 2593. H.B. 2593 would have: (1) limited the amount that could be borrowed in a "deferred presentment transaction" to the lesser of $\$ 2000$ or 35 percent of the borrower's gross monthly income; (2) limited rollovers ("consecutive reauthorizations") of these loans to three times; (3) applied any partial payment of the loan to the loan's principal; and (4) prevented any additional fees from being imposed once payment of $25 \%$ or more of the loan principal had been made. ${ }^{392}$

The regulatory ordinance proposed for Dallas required payday lenders to register with the city, and maintain complete records of all extensions of consumer credit. Far more controversially, the ordinance limited the payday loan to twenty percent of the consumer's gross monthly income and mandated that lenders maintain the documentation used to establish the consumer's income. Further, any loan involving a lump sum repayment could not be refinanced more than three times, and the proceeds for each loan renewal or extension must be used to repay at least $25 \%$ of the original principal. For loans involving installments, the proceeds from each installment must be used to repay at least $25 \%$ of the loan principal, and installment loans 
may not be extended, renewed, or refinanced. ${ }^{393}$ In short, the Dallas ordinance strongly resembled H.B. 2593.

Given the potential impact of the proposed Dallas regulatory ordinance on lenders, one might have expected the June 22 meeting of the City Council to be hotly debated by advocates and proponents. Instead, the ordinance, which was an addendum to the official agenda, passed without controversy or fanfare. Reverend Britt was the only person who addressed the City Council, and APC had sent a letter of support for the ordinance to Mayor Caraway and the City Council. (See Exhibit D.) That was the entirety of the visible lobbying. Councilmember Allen moved for passage of the ordinance and, after a brief discussion, it was passed unanimously. ${ }^{394}$ Within a month, the Consumer Service Alliance of Texas filed a lawsuit challenging the ordinance, but the suit proved unsuccessful. ${ }^{395}$ The genie was out of the bottle. The Dallas ordinance was to become the model for other cities in Texas. Within five years, similar ordinances passed, more or less verbatim, in more than thirty Texas cities. ${ }^{396}$

\section{Diffusion of Regulatory Ordinance to Additional Texas Cities}

Once Dallas passed the substantive local ordinance, other city councils around Texas followed suit. By 2013 , the number of similar ordinances had spread to six, and by mid-2016, thirty-five Texas cities had passed similar ordinances. ${ }^{397}$

\section{Jerry Allen and the Spread of Local Payday Loan Ordinances}

Councilmember Jerry Allen was not content with resting on the laurels he had gained by spearheading passage of the Dallas ordinance. Soon thereafter, he began going from town to town to help other municipalities pass regulatory-style ordinances. His approach was to look for like-minded councilmembers in these other cities. He believed that he just needed one and then he would do whatever it took to help him or her. He said: "Just give me one councilmember. I'll pick the phone up, I'll go down to do business with them, and if I have to, you know, I'll get on the plane. I'll go down there. If I get 'em one-on-one, I got 'em. I get anybody one-on-one, I'll get you." 398

Allen was careful not to frame his conversations with councilmembers elsewhere in terms of passing "the Dallas ordinance" but rather the Denton, Austin, or Mesquite ordinance. He elaborated: "If I am in San Antonio, I am not going to talk about how great what we did in Dallas was. No, I'm going to talk about what a great city San Antonio is: second largest city in Texas, proud history that has got the Alamo." ${ }^{399}$ 
Allen was happy to work behind the scenes or address the members of the city council in cities such as Amarillo and El Paso. Allen's approach was to focus on the city council's role serving the public. In Houston, Allen privately told the mayor, "You're a public servant. You're not a politician. Politicians know that these poor people don't vote, but you're a public servant and you're after their best interests. ${ }^{\prime 400}$ In addressing a city council, he said:

Fellow public servants - and I call you public servants. That's what you are because you care about people. That's why you're sitting here. That's why you're here today. What'd he [an industry spokesperson] just say? It kinda sounded like the Boogeyman, didn't it? Well, let's just open that closet door and take a look at that Boogeyman. He says, "We're going to have to leave Dallas."' I said, "You know what? Y'all remember reading the Consumer Financial Protection Bureau fined his company $\$ 10$ million for lying and mistreating the people?

Well, I don't know about y'all-yeah, I do. You're good, solid public servants. That's not the kind of company I want to see in Dallas. But let's take it a step further. He talked about other companies leaving. Well, yeah, we've had 'em leave. I had maybe 250 payday lenders; today, I've got maybe 125 . Well, guess what? Those doors are still open to those 125 , and our guess? They're still making money after three years. ${ }^{401}$

Jerry Allen's barnstorming was an important reason for the rapid spread of regulatory ordinances in Texas. Although he was careful not to be Dallas-centric, he encouraged other cities to keep things simple by passing an ordinance similar to the one in Dallas. Doing so would help Dallas and other cities defend their ordinances against industry claims that differing ordinances made compliance onerous. In his effort to promote uniformity, Allen also had the support of the Texas Municipal League. ${ }^{402}$

\section{The Non-Profit Texas Municipal League}

The Texas Municipal League (the Municipal League) is a non-profit association that assists Texas cities through legislative, legal, and educational activities. ${ }^{403}$ It was founded in 1913 as a way to allow leaders and officials of Texas municipalities to confer with each other on issues facing their individual cities. ${ }^{404}$ As of 2016, the Municipal League had 1,150 members-virtually all of the state's cities, towns, and municipalities.

The Municipal League has been instrumental in the state's fight against payday loan businesses, especially through its dissemination of a model payday loan ordinance based on the Dallas 
regulatory ordinance and its extensive coverage of news pertaining to the passage of ordinances and legal challenges to them. ${ }^{405}$ The model ordinance is seven pages long and contains options for minor modifications to the Dallas ordinance. ${ }^{406}$ The model ordinance has made it easy for Texas cities to pass a Dallas-type ordinance. The model ordinance, by encouraging cities to pass identical or very similar ordinances, undercut the ability of the payday lending industry to claim that compliance with a patchwork of differing ordinances would be an undue burden and therefore is or should be preempted by state law. The Municipal League's coverage of the litigation based on this preemption argument emboldens Texas cities, particularly given that industry litigation has been unsuccessful to date. ${ }^{407}$

\section{The Denton Story: Careful Planning Fueled by Outrage and Faith}

The passage of a regulatory-type ordinance in Denton shows the power of two individuals fueled by the injustice they found in payday lending. Pat Smith is a retired U.S. Air Force officer and directs the non-profit Serve Denton, which serves other Denton-based nonprofits through shared infrastructure. In 2012, Kayce Strader, fresh from earning a master's degree in nonprofit organizations, joined Serve Denton as its director of development. ${ }^{408}$

\section{Discovering Payday Lending in Denton}

Neither Smith nor Strader were familiar with payday lending until Smith and Strader attended a conference called No Need Among You, organized by Mission Waco, Mission World, on October 19, 2012. The conference sought to mobilize middle-class Americans to find "Christian-based, holistic, relationship-based" solutions to the problems of poor and marginalized people. ${ }^{409}$ In the case of Strader, the organization succeeded.

Strader attended a session called The Politics of Poverty by Suzii Paynter, which included the topic of payday lending. ${ }^{410}$ As Paynter described payday lending through statistics and anecdotes, Strader felt herself getting very angry. When people at the session started asking how these loans could be legal, Ms. Paynter said to the crowd, "That is your job. Go home and change it." Paynter advised people to talk to their city council members. As Strader exited the session, she ran into her colleague Pat Smith in the hallway. Smith immediately became concerned about Strader's physical well-being as she looked ill. He asked her if she was O.K. and Strader answered that she was, but she informed Smith that they had a job to do when they got home. Strader had become aware of a serious injustice, and her Christian faith impelled her to act. ${ }^{411}$ While stories about how benevolence ends up in the hands of lenders galvanized their campaign, for both Pat Smith and Kayce Strader, injustice was the primary fuel in their campaign for payday reform. 


\section{Finding an Inside Champion in Denton}

Two weeks later, Smith and Strader met with Kevin Roden, a young member of the Denton City Council who was first elected in 2011. They had lunch in a Chinese restaurant and shared what they had learned about payday lending at the Christian conference with Roden. Smtih chose to contact Roden because he viewed Roden as supportive of grassroots efforts and making local government work for people. According to Smith, "Roden is a big believer in local government. He's said many times in different web posts that he believes local government is more impactful than any national election or national policy ever could be, so he's really, I would say, a lover of local government." ${ }^{412}$

At the lunch, Roden said that he had heard a bit about payday loans but was not familiar with their details. Rodin knew they were financial products for the poor and felt they might be connected to neighborhood blight, but he did not know how much the loans affected his community.

Based on his conversation with Smith and Strader, Roden agreed to try to help change the law in Denton, and he gave Smith and Strader advice on how to move forward with other council members. According to Strader, Roden gave them the breadcrumbs and said, "This is the path you need to follow." ${ }^{413}$ At the same time, Roden was very careful not to get too involved because it might compromise his ability to serve as the ordinance's inside champion on the city council. He opened the door to get Smith and Strader access to one city councilman and then another. According to Strader, Roden told them to be well prepared and very organized when they came to the city council meeting at which the ordinance would be discussed.

\section{Lobbying the City Council in Denton}

The Denton City Council is composed of a mayor and six other council members. Smith and Strader knew that there was an informal rule about city council people meeting outside a public meeting in groups of three or more, so they met with the remaining city council members in groups of two and began cultivating relationships with them, if they did not already have them.

Strader and Smith also reached out to local non-profits and churches for support, resulting in the formation in early December, 2012, of Denton for Fair Lending. In addition to Serve Denton, the coalition included: Hope, Inc., Village Church, Vision Ministries, and the United Way of Denton. The United Way of Denton was initially quite cautious about supporting the local ordinance because it did not want to upset some of its donors. Fortunately, Smith was very 
good friends with the president of the Denton United Way, Gary Henderson, and according to Smith:

A turning point for [Gary] was when we had a meeting with Councilman Allen from Dallas, and United Way of Dallas attended that meeting. The United Way had launched Bank On here in Denton and in Dallas, and that flipped the switch for Gary and he became a very strong supporter of the ordinance. ${ }^{414}$

As had been the case in Dallas, non-profit social service organizations came to realize that the benevolent aid they were providing ended up indirectly in the hands of payday lenders. Longtime Denton resident Janet Shelton is on the board of Giving Hope, which was one of the big nonprofits that tracked whether people had payday loans. She informed the staff of Giving Hope to watch for people with payday loans, and the staff concluded that over $50 \%$ of the dollars that they distributed to help the poor were being used to offset payday lending. ${ }^{415}$

The members of Denton for Fair Lending had to move fast because they were scheduled to make a presentation at the December 18 meeting of the City Council. Following Roden's admonition to be well prepared, the coalition found a talented graphic designer to create flyers to be used at the meeting. ${ }^{416}$ (The designer worked for free because he believed in the cause.) The flyers employed the same graphic theme as the polished Prezi presentation that the members of Denton for Fair Lending gave in tag-team fashion at the meeting. ${ }^{417}$ The presentation ended with a request for three actions: (1) add predatory lending to the city's lobbying agenda at the state legislature, (2) pass a zoning ordinance similar to those in Dallas, Austin, and San Antonio, and (3) enact a regulatory ordinance similar to the one in Dallas that requires repayment of payday loans and auto title loans in no more than four installments. ${ }^{418}$

As coincidence would have it, the audience for the hearing was larger than expected because the agenda item right after the payday loan ordinance was a proposed bill that would outlaw smoking in bars. The room was packed, and while many in the crowd did not know the details of payday lending, they cheered after the payday presentation and gave the people from Denton for Fair Lending a standing ovation. Some people in attendance said it was the best presentation they had ever heard. ${ }^{419}$

An initial sign that the work of Denton coalition was paying off came on January 15 . The Denton City Council addressed the first request made by the coalition to press for state-level change. The Council passed a resolution "to enact laws to reduce exploitative payday lending and auto title loan practices." 420 The resolution also expressed support for the cities of Dallas, Austin, and San Antonio in their efforts to regulate these lenders. With the resolution passing 
unanimously, the City Council tacitly committed itself to taking further action to control lending within its borders.

Subsequent to the City Council meeting, Smith, Strader, and the members of Denton for Fair Lending continued to gather research to bolster their case. With the help of Ann Baddour at Texas Appleseed, they extrapolated to Denton the results of a recent study by Tim Lohrentz of the Insight Center for Economic Development showing the negative net economic effect of payday lending on communities. ${ }^{421}$ To supplement this economic research, Strader and Smith reached out to nonprofits to gather personal stories that exemplified the problems with payday loans. They asked the nonprofits, "Are people coming to you for food because they're spending their money on payday loans?" 422 Smith and Strader also got some non-profits to add questions on their intake forms: "Are you paying on a payday loan? Are part of your financial struggles due to a title loan " $^{423}$ In this way, Smith and Strader were able to obtain anecdotal stories from borrowers.

One such story involved Dorothy, an 86-year-old widow. Strader and Smith learned about her when a church member, who was her neighbor, was concerned about Dorothy's health because she was living on crackers. Dorothy's husband had been a POW in World War II and had passed away. Dorothy had gone to get a $\$ 75.00$ payday loan to pay insurance on her car and the loan ended up costing her nearly $\$ 10,000.00$ in combined loan payments and overdraft fees.

Dorothy was hospitalized for stress related to the loan. When Smith and Strader sat down with Dorothy and started unpacking what was going on, they realized this was "just pure hell for her." 424

\section{Final City Council Meeting in Denton}

Like in Dallas, Denton for Fair Lending benefited from a good relationship with one of the lead reporters at the local paper, the Denton Record-Chronicle, Peggy Heinkel-Wolfe. ${ }^{425}$ HeinkelWolfe and her colleagues provided in-depth coverage of payday lending in Denton as part of an annual feature called "Sunshine Week." As Pat Smith explained regarding Sunshine Week: "The paper picks a topic each year to pull the cover off and shine a light on it. In 2013, they picked payday lending. ${ }^{426}$ Thus, somewhat serendipitously, Smith and Strader had an ally in exposing the problems associated with payday lending and a means of publicizing their room efforts. The newspaper ran a series of articles during the second week of March, 2013, just a few days before the meeting of the City Council in which a regulatory ordinance would be considered. ${ }^{427}$

Members of Denton for Fair Lending attended the March 13 City Council. They sported stickers with the words: Texans Deserve Better/Stop Predatory Lending. Five people spoke about the ordinance, and all were in favor of it. They included coalition leaders Kayce Strader, Pat Smith, 
and Pastor Joe Ader. ${ }^{428}$ No one spoke against the ordinance, and it passed unanimously. That night, Ader went to the Facebook page of Denton for Fair Lending and wrote: "Thank you for all of the citizens-from the Boy Scouts to AARP to churches and everything in between-who came out in support over the last few months and tonight." ${ }^{429}$

\section{Payday Industry Strategy and Response in Metropolitan Dallas}

As set out above, representatives of payday lenders rarely testified, or even attended, zoning or city council meetings. Walter Moore did not find this particularly surprising in the case of zoning ordinances because payday outlets were already at a saturation point. He thought the payday industry was willing to lose on the Dallas zoning ordinance if it could win on ordinances that regulated business practices. Moore said: "Payday lenders were just going to throw up their hands and say, 'You can have the zoning ordinance.",430

The industry defended itself in ways other than appearing at public hearings, however. The chief spokesman for the industry was Rob Norcross of the Consumer Service Alliance of Texas. The starting point of his view of any regulation of payday lending is that the loans meet a need and are better than alternatives such as bouncing checks or frequenting loan sharks. He said: "It's access to credit on terms and conditions that are more favorable than the other options that most of our customers have. ... I think people are making rational financial decisions based on options available to them." ${ }^{431}$ According to Walker Moore, an industry representative asked the people attending a hearing to "Raise your hand if you have a mortgage." When everyone raised their hands, then he said, "Raise your hand if you want the city involved with what kind of mortgage you can take out." ${ }^{432}$ The industry's argument was that the city should not be involved in regulating people's financial transactions.

Norcross also frequently stressed the economic contribution of payday lending to communities and the state. He pointed out that the industry employed almost eight thousand people in the state of Texas and paid tens of millions of dollars in property taxes and rent. ${ }^{433}$ According to AARP's Susan Williams, the industry's arguments have changed over the years from arguments about unmet need to arguments about how the real answer was fighting for a living wage. A last ditch pitch by industry was to argue that cities ought to wait and see what the Consumer Financial Protection Bureau (CFPB) proposed before passing local ordinances. Jim Mitchell of the Dallas Morning News noted the irony of this last argument: "There was a time when the payday lenders - the big ones-were saying, 'We don't like [the CFPB's] intervention.' Then, once the power started to shift to the cities, the message changes to let's wait and see what the Feds do." 434 
Whereas the payday industry aimed its specific objections to additional regulation at policy makers, it tried to build support for itself among the general public via charitable giving and advertising. ACE Cash Express has been particularly active in terms of donating to worthy causes in its home region and elsewhere. ${ }^{435}$ Reverend Britt expressed skepticism about donations from industries that, he believes, help keep poor people poor. He cited the case of an industrial recycling plant located in a low-income area that stepped forward with the money for a Fourth of July fireworks celebration when the City of Dallas cancelled because it was too expensive. Britt said this type of public relations effort projects companies as good corporate citizens while, in reality, they are "robbing these neighborhoods of economic vitality." 436

Lenders also upped their advertising in an attempt to paint themselves in the most favorable light possible. As Josephine Lopez Paul explained, "We could tell that the industry was feeling pressure because they started putting up billboards all along [Highway] 360 and running radio ads saying, 'ACE Cash Express, your hometown lender since 1960.'”437

The payday industry's major force of resistance to regulatory ordinances was reactive: it raised the specter of lawsuits. Councilmember Allen recalled being threatened with a lawsuit after the business regulation ordinance passed in Dallas:

A payday guy, he came up to me and he said, "Well, Councilman, you know we're gonna have to sue you. We're gonna have to sue the city." And I said, "Well, partner, that's exactly what we want you to do 'cause we're gonna get your ass in the court of law and we're gonna whip you, but more importantly, we're gonna get your ass in the court of public opinion and we're really gonna whoop you there." We weren't blinking. ${ }^{438}$

The industry was good to its word and filed suit against the Dallas ordinance three weeks after it passed. Three years later, in May, 2014, a Texas Appeals Court ruled against the payday lending trade association and two individual companies, closing the matter. Journalist Jim Mitchell explained the critical importance of getting that first ordinance passed and that first lawsuit won:

At the local level, I mean I think the cat was out of the bag. Once the Dallas ordinance was passed and it was challenged and [the industry] lost, it left no other refuge other than the state or the hope that somehow the federal government intervenes and gives them a more flexible regime going forward. ${ }^{439}$ 
The anger of lenders at the legal outcome of the Dallas case and a similar unsuccessful challenge in Denton was no match for the righteous indignation that motivated people such as Kayce Strader, Reverend Britt, and Councilmember Allen and for the social movement they helped create. In the summer of 2016, the Texas Supreme Court refused to hear an appeal of the decision on the Denton ordinance, a huge victory for the cities. ${ }^{440}$ 


\section{Campaign Impacts}

\section{Types of Impacts}

Based on the three locally-based campaigns described in this report, we identify five categories of impacts. These impacts pertain to: (1) local payday law, (2) payday lenders and loans, (3) state and federal policymaking, (4) public awareness and opinion, and (5) community cohesion, organizational and individual empowerment, and faith development. Some of these impacts are readily observable while others are more speculative or, at least, hard to measure. Although a few of the impacts are unique to a particular time and place, most are likely replicable in other locations.

\section{Impact on Local Law}

The most direct and visible impact of the local campaigns described in this report has been the rapid spread of local payday loan ordinances in the three locales studied. As of late-2016, there were eleven "density-type" zoning ordinances in Salt Lake County and fourteen such ordinances (or bans) in the two counties that compose Silicon Valley. ${ }^{441}$ The situation in the Dallas area (defined as areas within Dallas, Denton, and Tarrant counties) is more complicated because there are ten density-type and eight "business regulation" ordinances, with three cities having both types (Dallas, Garland, and Mesquite). In the cases of Dallas and the Silicon Valley, the diffusion of the ordinances was the result of a sustained and well organized effort by a coalition of organizations. A less powerful coalition was present in Utah, but concern among officials in Salt Lake County cities that restrictions in a nearby city would lead to spillover of lenders into their city helped propel passage of numerous ordinances.

The diffusion effect of early ordinances in the three locales studied extended to other areas of their respective states. In Utah today, there are density-type ordinances in eight of the state's largest cities, including two of the state's three largest cities outside of Salt Lake County (i.e., Orem and Ogden). In California, Silicon Valley was not the site of the state's first anti-payday ordinances, but activity in Silicon Valley galvanized efforts elsewhere, including Long Beach (2013) and Fresno (2014). ${ }^{442}$ In Texas, after Dallas passed its business regulation ordinance, highly similar ordinances spread quickly throughout the state and now cover the jurisdictions in which over nine million Texans live. ${ }^{443}$ As Reverend Britt of Dallas CitySquare explained:

The ordinance movement has made a difference in terms of the sheer number of cities that have adopted the ordinance. I've just recently read about thirty cities that have adopted it. So I think that's made a difference, and if there's been any influence on the 
industry that has made them change their message, it's been these ordinances that other cities [beyond Dallas] have adopted. ${ }^{444}$

As set out in the first part of this report, the three campaigns we studied are part of a movement that goes well beyond these three campaigns. Since the first ordinances in Metropolitan Salt Lake City in the early 2000s, the number of local ordinances nationally has grown dramatically.

\section{Impact on Lenders and Loans}

While it is easy to measure the proliferation of local ordinances, it is much harder to measure their impact on payday lenders and payday loans in the regions studied. Given the focus of most zoning ordinances on lender density, one would expect to observe a short-term stabilization in the number of lenders in ordinance jurisdictions. Eventually, there might be a decline in lender numbers as some close their doors and new lenders are prevented by the ordinances from taking their place.

A decline in the number of lenders was predicted or subsequently reported by members of the payday industry. In San Jose, California, the California Chamber of Commerce argued that restricting payday lenders would lead to shop closures and make companies think twice about trying to open new ones. ${ }^{445}$ In 2014, Rob Norcross of the Consumer Service Alliance of Texas argued that Fort Worth should not enact a payday ordinance because the Dallas ordinance had resulted in 107 payday loan shops closing, "which meant 205 workers were laid off and \$5.9 million in annual wages and benefits lost." 446 In filing a legal challenge to the ordinance passed in Denton, Texas, ACE Cash Expressed stated: "As a result of the enactment of this Dallas Ordinance, ACE has lost most of the customers served by, and the majority of revenue formerly earned in, its Dallas locations. In fact, multiple ACE storefronts in Dallas have closed or will close as a result of the impact of the Dallas ordinance." ${ }^{447}$ In Austin, Texas, the lender Check ' $n$ Go said it was closing about half of its stores due, in part, to the city's new ordinance. ${ }^{448}$

Whereas payday lenders cite the loss of outlets-and the attendant jobs and taxes-as a means of dissuading restrictions in additional cities, anti-payday advocates view declines in payday stores as a sign of success. Several of our Texas interviewees mentioned that the numbers of lenders had gone down, citing industry claims regarding closed stores. ${ }^{449}$ Dallas City Councilmember Jerry Allen reported a drop from 250 to $125 .{ }^{450}$ AARP's Susan Williams recalled reading in the Dallas Morning News that the number had dropped from 220 to $190 .{ }^{451}$ Similar drops in lender numbers have been reported in the media for other Texas cities. A recent news account regarding San Antonio's ordinance reported that the "number of payday lenders 
operating in San Antonio has been cut in half since a city ordinance seeking to end 'abusive and predatory lending practices' took effect in 2013." 452

As eagerly as anti-payday advocates might wish to believe that zoning ordinances are responsible for stabilizing or causing a decline in the number of lender outlets, there are several reasons to be cautious about drawing any conclusions. The absence of growth in payday lenders could reflect a saturated market at the time when an ordinance was passed, and a decline could be attributable to the growth of the internet as an alternative channel for consummating payday loans. Similarly, a decline in lender numbers might be due to macroeconomic factors. At least in California, the economic recession that began in 2008 appears to have been responsible for a general decrease in new licenses for payday stores, including jurisdictions without ordinances. ${ }^{453}$ Our own analysis shows, however, that the decline was more rapid in California jurisdictions with ordinances than in those without them. ${ }^{454}$

\section{Effect on State and Federal Payday Loan Regulation}

In addition to passing local ordinances, local payday loan advocates in Utah, California, and Texas also worked to influence their state-level lawmaking processes as well as federal policymaking. In Utah, the same coalition of religious organizations that propelled passage of city- and county-level ordinances also provided the public pressure for several state-level reforms, including those in 2014 and 2016. ${ }^{455}$ In California, state-level efforts by anti-payday advocates have been particularly energetic. For example, representatives from the Center for Responsible Lending ( $C R L$ ), California Reinvestment Coalition (CRC), and Public Interest Law Firm of the Silicon Valley (PILF) spoke at a Banking and Finance Committee Hearing of the California Legislature held on January $11,2016 .{ }^{456}$ The hearing included testimony about why efforts to curb payday loan abuses were necessary on the state level, plus favorable comments

on the Consumer Financial Protection Bureau's (CFPB) proposed payday loan regulations. ${ }^{457}$ In 2013, PILF, CRC, La Raza, and the Silicon Valley Community Foundation (SVCF) supported a California Senate bill that would have increased the minimum duration of payday loans; required lenders to underwrite loans; capped the maximum number of loans per customer at four per year; and required the Commissioner of Corporations to develop and implement a database to help enforce the law. ${ }^{458}$ These and other advocates also spoke-this time successfully - in favor of California SB 318 (2013), which sought to create alternatives to payday loans, and in opposition to AB 1158 (2011), a bill proposed by lenders that would have raised the maximum dollar amount of a California payday loan from $\$ 300$ to $\$ 500 .^{459}$

Advocates who cut their teeth on local ordinances also graduated to federal-level lobbying as well. For example, the CRC created a petition on its web site that urged the CFPB to issue strong consumer protections in its payday loan rules. ${ }^{460}$ In July, 2016, SVCF advocated for strong 
federal reform at an Oakland town hall meeting with CFPB Director Richard Cordray. ${ }^{461}$ A year earlier, SVCF organized a letter from fifty-seven community foundations addressed to Cordray. The letter asked him to "enact comprehensive and stringent federal rules to govern payday lenders." 462 In the Dallas area, advocates made similar efforts to make their voices heard by the state and federal officials, including public defenses of the CFPB's payday lending rulemaking by Reverend Gerald Britt, Jr. and the Dallas Anti-Poverty Coalition. ${ }^{463}$

Advocates not only expanded the scope of their efforts from the local to the state and federal; their campaigns had the same effect on some local officials. Mike Guingona, drawing on his experience on the Daly City Council, wrote a letter to the CFPB urging payday lending reform. ${ }^{464}$ Dallas Councilmember Jerry Allen used a guest column in the Dallas Morning News to argue that the unwillingness of the Texas Legislature to enact meaningful payday reform left the CFPB as the best alternative for controlling the industry. ${ }^{465}$

In other instances, the migration of city officials to supporters of state- or federal-level payday reform might take place in the future. For example, both candidates emerging from the 2016 primary contest for California's $27^{\text {th }}$ Assembly District-Madison Nguyen and Ash Kalra-went on record while serving as members of the San Jose City Council as favoring payday lending reform. ${ }^{466}$ Kalra ultimately won the election, meaning the State Assembly will have a new member with a history of actively opposing payday lenders. ${ }^{467}$

\section{Public Awareness and Opinion Regarding Payday Lending}

City councilmembers, not members of the general public, make the final decision regarding the enactment of local payday ordinances. Nevertheless, public opinion is an important influence on the priorities of policy makers. Local anti-payday advocates have therefore expended considerable effort to generate public support of their ordinance campaigns as well as use these campaigns to deepen public awareness and opposition to payday lending. Advocates employed the following methods of influencing public awareness and opinion regarding payday lending: contributing quotes to media coverage of payday lending and reform efforts; using newspaper columns, websites, and blogs to disseminate their views in greater depth; paying for advertising; and embedding the topic of payday lending in financial education programs.

In Utah, advocates had few resources to measure or influence public sentiment about payday lending. The one exception was newspaper coverage. Both of the major papers in the Salt Lake area, The Salt Lake Tribune and the Deseret News, conducted original research on the problems associated with payday lending and covered the activities of advocates to reform the industry at the local and state levels. A primary example was a three-day series published in the Deseret News in November, 2005-a time when only a few Utah cities had passed payday ordinances. Linda Hilton of the Coalition of Religious Communities was quoted in each of the articles. In the 
first, she described the industry as "legalized loan sharking." 468 In the second, she decried Utah's weak payday lending regulation. ${ }^{469}$ In the third article, Hilton enumerated the many obstacles to payday reform at the state level, including a powerful financial services lobby. ${ }^{470}$

The willingness of journalists to cover the payday industry was virtually the only method available to advocates in Utah to influence public awareness and opinion. In the Dallas area, advocates also enjoyed favorable news coverage from the Dallas Morning News and they were invited regularly to contribute guest opinion columns. In addition, Dallas advocates employed the internet via blogs and social media. Starting in 2008, Reverend Gerald Britt authored a blog titled "Change the Wind" in which he tracked the progress of local and state payday reform efforts. In Dallas and Denton, advocates maintained actively-used Facebook pages. ${ }^{471}$

The most extensive effort to measure and influence public sentiment took place in Silicon Valley. In addition to favorable and extensive media coverage and a Facebook page for the Coalition Against Payday Predators (CAPP), advocates were able to gauge public opinion via a professional survey, buy advertising on the sides of San Jose buses, and embed the subject of payday lending in financial education programs. In November, 2010, Goodwin Simon conducted a telephone survey of 400 registered voters living in San Jose. ${ }^{472}$ The survey, commissioned by the Center for Responsible Lending and paid for by a grant from the Silicon Valley Community Foundation, examined attitudes about payday lending and levels of support for tighter regulation of the industry, including local zoning restrictions. Responding to the survey results, San Jose City Councilmember Ash Kalra observed: "Payday loans are harmful products, and this poll demonstrates that San Jose voters know it." ${ }^{473}$ At a smaller scale and less professional level than in San Jose, the Youth Leadership Institute conducted a face-to-face survey about payday lending with a non-random sample of Daly City residents. Again, the survey was used to make the case for a local ordinance. ${ }^{474}$

Silicon Valley advocates did more than gauge public opinion; they tried to change it. In mid2012 , shortly after passage of the San Jose ordinance but before enactment of several others in the Silicon Valley, CAPP purchased advertisements on the sides of buses that circulated throughout Santa Clara County. ${ }^{475}$ A more personal and individualized effort to influence public opinion regarding payday lending was via financial education classes. SVCF and other Silicon Valley ordinance supporters considered financial literacy and asset building keys to making payday loans unnecessary. SVCF's chief executive, Emmet D. Carson, said: "The financial literacy piece of this is the core. I can't stress that enough." 476

Putting financial literacy into action, Community Legal Services of East Palo Alto (CLESPA), Nuestra Casa, and the entrepreneurship-oriented Renaissance Mid-Peninsula offered consumer education classes to help people develop financial skills sufficient to free them from at least 
some payday loans. Nuestra Casa also incorporated education about payday lending into a class for undocumented residents seeking a driver's license under a new California law. The theory behind including payday lending education was that getting a license involves buying a car, and buying a car entails understanding credit, and understanding credit includes avoiding high-cost forms of borrowing such as payday loans. ${ }^{477}$ In Pacifica, an SVCF-grantee developed a small-scale program to help borrowers pay off payday loans and then learn to build assets capable of covering an emergency. ${ }^{478}$

Ordinance advocates did not have the capability of measuring the impact of particular activities on specific aspects of public awareness and opinion regarding the payday lending industry, but several advocates believed that their efforts contributed to a cultural shift in the way payday lending is viewed by society. As Reverend Britt of Dallas CitySquare stated:

We have been a significant voice bringing payday lending to the public consciousness, and we've actually changed the conversation about payday lending and about financial literacy and the need for financial literacy, not just among lower to middle class people, but for everybody. I don't think that that would have happened if we hadn't done this.

In California, James Zahradka, formerly of the Law Foundation of Silicon Valley, thought his coalition's efforts created a cultural sea change in which lenders were associated with societal ills. Zahradka explained the importance of getting city after city on record saying that payday loans are toxic products, and while legal, they are "a noxious land use, like an adult bookstore or a liquor store or whatever. We're regulating them like that. That's a very powerful message that it is getting into the national culture more and more." ${ }^{479}$

\section{Impact on Community Cohesion, Organizational Capacity, and Individual Development}

In all three study locations, advocates worked in coalitions and drew together numerous and sometimes quite disparate groups. In Utah, the Coalition of Religious Communities (CORC) was the major voice for payday reform. In the Silicon Valley, SVCF used the grant-making process to draw together groups already engaged in payday loan reform with additional organizations that had a broad commitment to fair lending but limited direct experience with payday advocacy. In Santa Clara County, the Coalition Against Payday Predators (CAPP) was chiefly responsible for promoting local payday ordinances. With help of SVCF funding, CAPP had the advantage of professional leadership from Kyra Kazantzis of the Law Foundation of Silicon Valley and Liana Molina of the California Reinvestment Coalition. CAPP brought together social service, religious, labor, and community empowerment organizations, and it was formally endorsed by representatives of the Asian-American, Mexican-American, Native-American, and African- 
American communities. In San Mateo County, alliances were more informal, but a common relationship to SVCF provided a network for sharing ideas and experiences.

The most broad-based coalition emerged in Dallas. The Anti-Poverty Coalition of Greater Dallas (APC) was extraordinary in the extent that it crossed boundaries of religious, race, and social class. Even more remarkable is that APC functioned without generous financial resources. In this sense, it was more "organic" than the coalitions in Silicon Valley. Reverend Britt, one of APC's leaders, described it as the most resilient and nimble coalition with which he had ever been involved. ${ }^{480}$

The various coalitions flourished, in part, because their leaders purposefully made group members responsible for prioritizing efforts. In both the Silicon Valley and in Dallas, coalition leaders allowed members of the group to set their own priorities in choosing to organize around payday lending. No one was asked to take on a cause about which he or she did not feel passionate. This passion built the buy-in and perseverance needed to get the job done. When people from different backgrounds stand together to support payday ordinances, it speaks loudly about what society wants and needs. Broad-based support also helps negate lender arguments that payday loans respond to genuine borrower needs in a community. But beyond pressuring for local payday ordinances, collective efforts helped build "empathy bridges" among people from different backgrounds. ${ }^{481}$ Members of APC, CAPP, as well as advocates in San Mateo County reported that they now feel more comfortable working within in coalitions generally, not just those that were used for payday campaigns. For CORC and APC, payday lending was always part of a much broader social justice agenda, but the continued existence of CAPP suggests that it too has tapped into a need for community cohesion and progress on additional issues of community concerns. At a time in this country when divisions of all kinds are at their deepest in recent history, examples of communities coming together are precious.

\section{Helping Organizations and Individuals Find Voice in Policy-Making}

One of the most powerful human skills is the ability to "speak in one's own voice with full authority." ${ }^{482}$ Working on a campaign that achieves its goal of passing a local ordinance can help advocates, including payday loan customers who share their stories publicly, to find voice, power, and purpose. In Utah, advocate Art Sutherland was transformed by his experience working for payday reform. As a semi-retired engineer, he was looking for a way to use his talents to help society. ${ }^{483}$ As a result of his anti-payday efforts, Sutherland became a nationallyhonored consumer advocate. ${ }^{484}$ Another example involving much younger people comes from Silicon Valley where the anti-payday lending movement included two organizations that develop the leadership skills of youth. ${ }^{485}$ Through their campaigns against payday lending, the young people organized by the Youth Leadership Institute (YLI) and its partner Mission SF (now 
MyPath) learned to identify social problems, find their own voice in community, and navigate the political process.

In another example of empowerment, Danielle Ayers, Minister of Justice of Friendship-West Baptist Church, explained that after passing an ordinance, church members "felt good, felt that that they had succeeded at something, that there was good news." ${ }^{486}$ Several years later, the congregation remained mobilized. A plant nursery located near the church closed and was replaced by a title lender. ${ }^{487}$ Through the church's advocacy, the lender was forced to leave after it had gone through the expense of opening for business. Subsequently, the restaurant chain Raising Cane's Chicken Fingers moved in, creating a huge, visible victory for the community. Ayers commented:

When that title loan store closed, we announced it [in church]. People were excited. ... Even if they didn't march [in a particular payday loan protest], they were happy. ... And the ones who did march, this was a way for them to sharpen their advocacy skills and also to see that, in the end, we can win. But it takes us doing our part. ${ }^{488}$

Some campaigns taught payday loan borrowers how to become advocates. For example, Silicon Valley direct service providers, Sacred Heart Community Services and Somos Mayfair, helped identify payday borrowers to get specific stories about the harms of payday lending for the cause. Sacred Heart went one step further and convinced borrowers to speak publicly about their experiences with payday loans. Christian Luna, a program manager at Sacred Heart, explained how the method of finding victims and empowering them to speak helped borrowers grow as individuals and feel part of something meaningful. Developing these skills is now part of Sacred Heart's standard operating procedure.

Helping individuals find their voice was not limited to members of non-profits, religious congregants, or payday loan borrowers. Stephanie Mace of the United Way of Metropolitan Dallas (Dallas United Way) explained how the United Way took wealthy United Way donors and educated them about how payday loans worked, how little protection the law provided, and then encouraged them to go to state or local politicians and talk to them about changing the law to help serve people, not payday lenders. The United Way trained, with the help of Ann Baddour of Texas Appleseed, some of these high-end donors to pose as borrowers and to go into stores and do secret shopper experiments. The donors asked for a loan of say $\$ 500$ and asked questions to see not only what it felt like to borrow in this way, but also what terms were offered and how much information one could glean before taking out the loan. ${ }^{489}$ 
As a result of direct exposure to payday lending, several major donors of the Dallas United Way learned that their voice could complement their money in seeking to change in the world. Mace explained:

At United Way, our mission is to change lives forever. And we encourage people to do that by giving, by volunteering, and by advocating. So, this is kind of that third pillar, by advocating. And one of the things that I think is very unique to United Way is that it's not just United Way staff or the organization that advocates. We actually train our major donors to go out and to visit - to go to Austin, we've gone to DC - to visit with elected officials. To educate them on these issues; how it impacts the community, see where their money is going-it's their money. ${ }^{490}$

In addition to helping individuals find voice, organizations themselves were transformed through the local ordinance movements. Christian Luna, for example, said that as a result of Sacred Heart's advocacy work around payday lending, Sacred Heart became an advocacy organization, in addition to a direct service provider. Similarly, Kyra Kazantzis, lead organizer for the legal service provider Law Foundation of Silicon Valley, said that as a result of organizing a payday reform coalition, her organization more strongly embraced policy advocacy as a complement to legal service provision and litigation. Regarding the Silicon Valley Council of Nonprofits, Kazantzis said, "Payday lending really solidified, in that entity's mind, that nonprofits should absolutely be doing policy advocacy."

\section{Faith Development}

In all three case studies, religious organizations played an important, and often crucial, role. While religious convictions often motivated individuals to participate in payday campaigns, their convictions were reinforced and deepened through participation. This process is what Josephine Lopez Paul and Walker Moore of the Industrial Areas Foundation called "faith development." As Lopez Paul explained:

This work [as a community organizer] is the development of people and helping them understand their own power in their community. I've organized in El Paso, and we passed millions of dollars of water infrastructure laws there, people in the Colonias. ... It's the same basic principles with payday lending-just listening to people and teaching them then how to act on what it is that they care about. . . It's really about the formation of people and the development of people. So for people like Father Dan [Kelley of St. Joseph Catholic Church in Arlington] to interact with 
members of the congregation [about payday lending], that's huge. The people in the congregation who had never been a part of anything like this before can suddenly say, "I can do something. And I'm a pretty effective speaker in front of the city council. I can make something happen. And this is a way for me to live out my faith." 492

Danielle Ayers called the same process "faith formation" and described connecting what is heard in church on a Sunday morning and

how we govern ourselves between Sundays. What does God have to say about our existential situation? What is going on? He cares. God cares about children who were impoverished and don't have food to eat. So, we try to connect those dots, and Dr. Haynes [Senior Pastor of Friendship-West Baptist Church] does an excellent job at opening up the text and giving it some original context. ${ }^{493}$

Finally, while developing their faith and their voice, people learned about the political process and how to hold politicians accountable. As Walker Moore explained, at St. Joseph's, a 5,000member church in Arlington, Father Dan Kelley threw himself into the payday loan cause and was a role model for constituents. A week before the Arlington City Council was scheduled to consider the payday ordinance, Kelley and other ordinance supporters were invited to address the Arlington Chamber of Commerce. As Moore recalls the event, Kelley entered the room and saw that one of his congregants was chairing the meeting. The councilmember was a "probusiness, anti-regulation guy." ${ }^{494}$ But the chairperson was now conflicted because "he's heard about all the anti-payday activity that has been going on at St. Joseph's, and he knows what faith says." Perhaps as a result of Father Dan's presence, the Chamber of Commerce took no position on the proposed ordinance rather than oppose it. ${ }^{495}$

Moore and Lopez Paul helped organize people to go and testify at the crucial November 10, 2015 City Council meeting in Arlington. Father Kelley was only one of ten people who spoke in favor of the ordinance. ${ }^{496}$ Moore noted that after Kelley spoke, members of the city council repeatedly quoted him when speaking in favor of the ordinance. ${ }^{497}$ In Arlington as in Denton and Dallas before them, members of religious communities found an opportunity to unite their faith and their politics.

\section{Concluding Thoughts on Campaign Impacts}

Any global assessment of what the local ordinance campaigns accomplished depends on the standard of success one uses. Few advocates operated under the illusion that local zoning 
ordinances, or even the business regulation ordinances possible in Texas, would put the payday lending industry out of business or even noticeably reduce the amount of payday borrowing. Reflecting on local ordinances, Professor Christopher Peterson, who had once encouraged his mother as a member of the West Valley City Council to pass an anti-payday zoning ordinance, expressed frustration at how little he thought local ordinances had accomplished. He said that local efforts, "instead of being a stepping stone in building more sustaining and more meaningful change, became a false lead in the maze that became a dead end." ${ }^{498}$ Peterson currently believes that the best possibility for lasting reform lies with federal action, as represented by Military Lending Act and, perhaps, the rules proposed by the Consumer Financial Protection Bureau.

Peterson was the lone voice of disillusionment among the people we interviewed. Dallas City Councilmember Jerry Allen was more representative and more modest in his expectations. He said: "I'm just a lil' ol' guy in Dallas, Texas. I can only punch them [the payday lenders] the way I can punch them." ${ }^{499}$ Most of the advocates of local ordinances felt compelled to "do something, do anything" about what they perceived as a financial practice that devastated the lives of their co-religionists, social service clients, or fellow citizens. They succeeded in their primary goal-to put in place local ordinances that, at a minimum, made a strong statement in opposition to the payday industry. But their actions appear also to have had numerous indirect and less readily measurable impacts. The advocates helped build a climate for further reforms at the state and federal levels by providing a new narrative. Rather than the payday industry's claim that their loans, while expensive, meet an urgent need when no other options are available, the new narrative defined payday loans are "debt traps" to which society has an obligation to build better alternatives.

Beyond any impact on payday lending itself, the campaigners changed others and themselves. In the process of opposing payday lending, campaigning organizations discovered that policy advocacy was consistent with other missions, such as providing services to low-income people. These organizations also came to realize the power of coalitions and developed trust in other organizations. Finally, individuals found their voice as active members of their communities and experienced the sense of empowerment that comes with matching beliefs with action. 


\section{Endnotes}

${ }^{1}$ In this report, we use the term "payday lending" to include auto title loans. Some of the local ordinances that we examine refer only to payday loans while others encompass payday loans, auto title loans, and, occasionally, other small-dollar loans such as high-cost installment loans.

${ }^{2}$ Salt Lake is shorthand for Salt Lake County, a jurisdiction with thirteen cities. Dallas is shorthand for Dallas and Denton counties. Silicon Valley refers to Santa Clara and San Mateo counties.

${ }^{3}$ To support the twenty-year claim, one can point to Michael Hudson's book, Merchants of Misery (Monroe, Maine: Common Courage Press). Jean Ann Fox's efforts go back at least as far as 1997. See: The High Cost of 'Banking' at the Corner Check Casher: Check Cashing Outlet Fees and Payday Loans (Washington, DC: Consumer Federation of America, August 1997).

${ }^{4}$ See Chester Hartman and Gregory D. Squires, editors, From Foreclosure to Fair Lending (New York: New Viking Press, 2013); Mary Lou Finley, Bernard LaFayette, Jr., James R. Ralph, Jr., and Pam Smith, editors, The Chicago Freedom Movement (University Press of Kentucky, 2016).

${ }^{5}$ Dan Immergluck, Credit to the Community (Armonk, NY: M.E. Sharp, 2004).

${ }^{6}$ See: Souphala Chomsisengphet and Anthony Pennington-Cross, "The Evolution of the Subprime Mortgage

Market," Federal Reserve Bank of St. Louis Review, January/February 2006, 88(1), pp. 31-56, https://research.stlouisfed.org/publications/review/06/01/ChomPennCross.pdf; Dan Immergluck and Marti Wiles, Two Steps Back: Predatory Lending, the Dual Mortgage Market, and the Undoing of Community Development (Chicago: Woodstock Institute, 1999); Michael Hudson, Merchants of Misery (Monroe, MA: Common Courage Press, 1996); Robert Mayer, Quick Cash (DeKalb, IL: Northern Illinois University Press, 2010); Christopher L. Peterson, Taming the Sharks (Akron, OH: University of Akron Press, 2004); Gary Rivlin, Broke, USA (New York, NY: Harper Business, 2010.

${ }^{7}$ Elizabeth Warren, “Unsafe at Any Rate," Democracy, A Journal of Ideas, Summer 2007, No. 5, http://democracyjournal.org/magazine/5/unsafe-at-any-rate/.

${ }^{8}$ Larry Kirsch and Robert N. Mayer, Financial Justice (Santa Barbara, CA: Praeger, 2013).

9 "A Lifetime of Assets-Asset Preservation: Trends and Interventions in Asset Stripping Services and Products," National Community Reinvestment Coalition and Woodstock Institute, September 2006, http://communitywealth.org/sites/clone.community-wealth.org/files/downloads/paper-ncrc-woodstock.pdf; Nicholas Bianchi, "Profiting from Poverty: How Payday Lenders Strip Wealth from the Working-Poor for Record Profits," A Report by National People's Action, Chicago, Illinois, January, 2012, http://npaus.org/files/images/profiting from poverty npa payday loan report jan 2012 0.pdf.

${ }^{10}$ Letter to the Honorable Richard Cordray, Director of the Consumer Financial Protection Bureau from 700 organizations on the letter head of Stop the Debt Trap, October 6, 2016, http://stopthedebttrap.org/wpcontent/uploads/2016/10/sign-on-comment.pdf.

${ }^{11}$ Jean Ann Fox, "Payday Loan Advocacy," in Watchdogs and Whisteblowers, eds. Stephen Brobeck and Robert N. Mayer (Santa Barbara, CA: Greenwood, 2015), 350.

${ }^{12}$ Some of the organizations that initially participated in Americans for Financial Reform (AFR) were primarily interested in aspects of the Dodd-Frank Act that had little to do with consumer protection and fair lending (e.g., systemic risk; financial derivatives; executive compensation). AFR continues to be engaged in a variety of issues, only some of which pertain to fair lending.

${ }^{13}$ Kelly Griffith, Linda Hilton, and Lynn Drysdale, "Controlling the Growth of Payday Lending Through Local Ordinances and Resolutions: A Guide for Advocacy Groups and Government Officials," October 2012, Appendix 1 Updated December, 2013, http://www.economicintegrity.org/files/cei zoning manual pdl-localordinance as of 11 16.pdf.

14 Ibid.

15 "Taking the First Step: Six Ways to Start Building Financial Security and Opportunity at the Local Level," Corporation for Enterprise Development (CFED), December 2012, http://cfed.org/assets/pdfs/Taking the First Step.pdf ; Adam B. Summers, "Payday Lending: Protecting or 
Harming Consumers? Policy Study 420," Reason Foundation, November 2013, http://reason.org/files/payday lending regulation.pdf.

${ }^{16}$ Tim Lohrentz, "Tools for Advocates of Limiting Payday Lending." Center for Community Economic Development, June 2013, http://ww1.insightcced.org/uploads/assets/paydaylending/plat.pdf.

${ }^{17}$ Griffith et al., op cit.

${ }^{18}$ While Arizona forbids payday loans, it has no restrictions on title loans, which are now extremely common throughout the state.

${ }^{19}$ The full list of interviewees is found in Exhibit A.

${ }^{20}$ The human subjects committees of the University of Utah and University of New Mexico approved subject recruitment and interview procedures. Study participants were asked in advance whether their interviews could be audio recorded, and permission was documented in writing or, more often, verbally at the beginning of each recording. Interviewees were told that they would have opportunity to review any quotations attributed to them in a draft of this report and, if they wished, have their quotations deleted. All participants gave their consent to be recorded under this condition.

${ }^{21}$ Fabrizio Gilardi, "Four Ways We Can Improve Policy Diffusion Research," State Politics \& Policy Quarterly 16, no. 1 (2016): 8-21, http://www.fabriziogilardi.org/resources/papers/Gilardi-SPPQ-2016.pdf.

22 “Marijuana Law Reform Timeline," Norml.org, accessed November 21, 2016, http://norml.org/shop/item/marijuana-law-reform-timeline.

${ }^{23}$ Policy entrepreneurs can be individuals or organizations, government insiders or activist outsiders, but they always display a willingness to invest their resources (whether money, time, energy, or reputation) to seek a policy change. They must also be well versed in government processes and be able to judge when windows of opportunity exist. See John W. Kingdon, Agendas, Alternatives, and Public Policies (Boston: Little, Brown, 1984); Michael Mintrom, "Policy Entrepreneurs and the Diffusion of Innovation," American Journal of Political Science 41, no. 3 (1997): 738-70.

${ }^{24}$ Christopher Peterson Interview, pp. 2-3.

${ }^{25}$ Rev. Gerald Britt, "Fighting Those Who Prey Upon the Struggling," Dallas Morning News, October $29,2010$.

${ }^{26}$ Kace Strader Interview, p. 3.

27 "A New Way Forward: A Look at Silicon Valley Community Foundation's First Year," Silicon Valley Community Foundation, accessed November 21, 2016, http://www.siliconvalleycf.org/docs/yearlnReview9 web2.pdf; "Community Economic Development Strategic Conversation Proceedings, South San Francisco, California, September 27, 2007," Silicon Valley Community Foundation, http://www.siliconvalleycf.org/docs/cip/CEDproceedings final.pdf.

28 "Grantmaking Strategies: Executive Summary," Silicon Valley Community Foundation, accessed November 21, 2016, http://www.siliconvalleycf.org/grantmaking-strategies/pdf/executive-summary.pdf.

${ }^{29}$ Jerry Allen Interview, p. 6.

30 John D. McCarthy and Mayer N. Zald, "Resource Mobilization and Social Movements: A Partial Theory," The American Journal of Sociology 82, no. 6 (1977): 1212-41.

${ }^{31}$ J. Craig Jenkins, "Resource Mobilization Theory and the Study of Social Movements," Annual Review of Sociology 9 (1983): 527-53.

32 "Grantees List," Silicon Valley Community Foundation, September 10, 2008, http://www.siliconvalleycf.org/grantees-list.

${ }^{33}$ Goodwin Simon Strategic Research, San Jose Payday Loan Store Restrictions Survey, Center for Responsible Lending, Goodwin Simon Strategic Research, Oakland, California, December 2010, http://www.responsiblelending.org/california/ca-payday/research-analysis/San-Jose-Payday-Lending-Voter-PollMemo.pdf; Goodwin Simon Strategic Research, Key Findings from Payday Loan Users Focus Groups, Goodwin Simon Strategic Research, Center for Responsible Lending, Oakland, California, December, 2009.

${ }^{34}$ David Rusk, Inside Game/Outside Game: Winning Strategies for Saving Urban America (Washington, DC: Brookings Institution Press, 1999).

35 “Anti Payday Lending Grantees 2011," Silicon Valley Community Foundation, accessed November 21, 2016, http://www.siliconvalleycf.org/anti-payday-lending-grantees-2011. 
${ }^{36}$ Patrick O'Keefe, Staff Report, City of South San Francisco, California, May 14, 2014, http://ci-ssfca.granicus.com/MetaViewer.php?view id=2\&clip id=762\&meta id=55980.

37 "Collaborating for Change: 2010 Year in Review," Silicon Valley Community Foundation, February 2011, http://www.siliconvalleycf.org/docs/svcf-year-end-report.pdf.

38 "Finding Alternatives to Payday Loans," California Money, KQED Radio, December 21, 2010, http://www.kqed.org/a/californiamoney/R201012210733.

${ }^{39}$ Coalition Against Payday Predators: When Cash Runs Out: Discussing the Spectrum of Alternatives," San Jose Peace \& Justice Center, February 2012, http://www.sanjosepeace.org/calendar_event.php?eid=20120203170509588.

${ }^{40}$ Ordinance No. 3002-13, City Council of the City of Sunnyvale, http://sunnyvale.ca.gov/Portals/0/Sunnyvale/CouncilReports/2013/3002-13.pdf.

41 "The Payday Problem: Fighting the Debt Trap Through Advocacy, Policy and Education," Silicon Valley Community Foundation, Spring 2011, http://www.siliconvalleycf.org/one-innovation-through-philanthropy/spring11/one-innovation-through-philanthropy-spring-11.pdf, p. 11.

42 "Anti Payday Lending Grantees 2012," Silicon Valley Community Foundation, http://www.siliconvalleycf.org/antipayday-lending-grantees-2012.

43 "Anti-Payday Lending Grantees 2015," Silicon Valley Community Foundation, http://www.siliconvalleycf.org/anti-payday-lending-grantees-2015.

${ }^{44}$ Britt, 2010, op. cit.

45 "A Toolkit for Cities: Increasing Access to Fair, Low-Cost Loans," Texas Appleseed, August 2016, https://www.texasappleseed.org/sites/default/files/Toolkit forCities Entire.pdf.

46 'Other Cities Following Dallas' Lead in Payday Loan Laws, Lake Highlands Advocate, September 7, 2011, http://lakehighlands.advocatemag.com/2011/09/other-cities-following-dallas-lead-in-payday-loan-laws/; "Hotly Debated Payday Lending Ordinance Passed by City Council," KSAT-12m September 20, 2012, http://www.ksat.com/news/hotly-debated-payday-lending-ordinance-passed-by-city-council; Ty Johnson, "Payday Loan Ordinance Gets Initial OK by Commission," Brownsville Herald, September 3, 2014, http://www.brownsvilleherald.com/premium/article a60b63c8-3313-11e4-80f9-0017a43b2370.html. 47 "Example Ordinance Disclaimer," Texas Municipal League, http://www.tml.org/payday-example-ordinance. 48 "Anti-Payday Lending Grantees 2013," Silicon Valley Community Foundation, http://www.siliconvalleycf.org/anti-payday-lending-grantees-2013.

${ }^{49}$ There may have been additional campaign impacts. In August 2015, Facebook banned advertisements from payday lenders. It might be purely coincidental, but Facebook's founder and CEO began making sizable donations to SVCF beginning in December, 2012, shortly after SVCF's success in getting payday ordinances enacted in San Jose and several other Silicon Valley cities. See: Nathan Oivarez-Giles, “Who's Getting Zuckerberg's \$1 Billion?" The Wall Street Journal, December 19, 2013.

${ }^{50}$ Jerry Allen Interview, pp. 5-6.

${ }^{51}$ Lee Davidson, "Utah Too Lax on Payday Lenders?," Deseret News, November 15, 2005, http://www.deseretnews.com/article/635159502/Utah-too-lax-on-payday-lenders.html?pg=all.

${ }^{52}$ Grantmaking Strategies: Request for Proposals: Economic Security Strategy: Anti-Payday Lending Policy Advocacy, Silicon Valley Community Foundation, June 18, 2009, http://www.siliconvalleycf.org/grantmakingstrategies/pdf/anti-payday-lending.pdf.

${ }^{53}$ Ibid.

54 “Anti-Payday Lending Grantees 2014," Silicon Valley Community Foundation, http://www.siliconvalleycf.org/anti-payday-lending-grantees-2014.

${ }^{55} \mathrm{Ibid}$.

${ }^{56}$ Larry James, May 27, 2016, "Join the Fight," Larry James' Urban Daily (blog), http://larryjamesurbandaily.blogspot.com/2016/05/join-fight.html; "Predatory Payday Lenders," CitySquare.org, August 2016, http://www.citysquare.org/predatory-payday-lenders/.

${ }^{57}$ Jerry Allen, "Commentary: Texas Needs a One-Two Punch Against Payday Lending," Dallas Morning News, December 16, 2015. 
${ }^{58}$ Letter to Richard Cordray on Office of the City Council, City of Daly City Letterhead, July 7, 2015.

59 "Coalition Launches Bus Ad Campaign to Discourage Payday Loan Usage Among San Jose Residents," California Reinvestment Coalition, June 2012, 9:00 a.m., http://www.calreinvest.org/news/coalition-launches-bus-adcampaign-to-discourage-payday-loan-usage-among-san-jose-residents.

${ }^{60}$ Keith Ogden Interview, pp. 17-18.

${ }^{61}$ Rev. Gerald Britt Interview , p. 52.

62 James Zahradka Interview, pp. 21-22.

${ }^{63}$ Newbaptistcovenant.org, accessed November 21, 2016, http://newbaptistcovenant.org/dallas-tx/.

${ }^{64}$ Mark Wingfield, "Wilshire Partners With Friendship-West," Wilshire Baptist Church, November 27, 2013, http://www.wilshirebc.org/media/blog/wilshire-partners-with-friendship-west.

${ }^{65}$ Christian Luna Interview, p. 4.

${ }^{66}$ The Silicon Valley Council of Nonprofits has two hundred members. It serves as the voice of nonprofit organizations in the Silicon Valley and seeks to increase the influence of nonprofits with respect to government entities and foundations. See: http://www.svcn.org/one-home.

${ }^{67}$ Kyra Kazantzis Interview, p. 44.

68 "Money Heroes: Art Sutherland," Time, accessed November 21, 2016, http://time.com/money/2905826/utah/.

69 "Profile," Youth Leadership Institute, accessed November 21, 2016, http://yli.org/wpcontent/uploads/2015/11/YLI-Profile-FY-15-16.pdf.

${ }^{70}$ Danielle Ayers Interview, p. 4.

${ }^{71}$ Stephanie Mace Interview, p. 4.

72 Josephine Lopez Paul Interview, pp. 28-31.

${ }^{73}$ Danielle Ayers Interview, p. 22.

${ }^{74}$ Walker Moore Interview, p. 7.

${ }^{75}$ Ibid., 8.

${ }^{76}$ Regulation of Check Cashing, Senate Bill 57, Utah State Legislature, 1999 General Session, http://le.utah.gov/ 1999/bills/sbillenr/SB0057.pdf.

${ }^{77}$ There is a minor discrepancy in the timing. In his interview, Chris says that he took the job right after college, but in an email to me Chris says he took the job just as he was finishing his degree.

${ }^{78}$ There are no good data on the number of payday lenders in Utah as of 1997, but Chris Peterson uses Yellow Pages listings to document the growth of the industry in the late 1990s. See: "Only Until Payday: A Primer on Utah's Growing Deferred Deposit Loan Industry," Utah State Bar, last modified March 7, 2002, https://www.utahbar.org/utah-bar-journal/article/only-until-payday-a-primer-on-utahs-growing-deferred-depositloan-industry/.

${ }^{79}$ Chris Peterson Interview, pp. 1-2.

80 "Check Cashers," Utah Department of Financial Institutions, last modified July 22, 2016, http://dfi.utah.gov/money-services/check-cashers/; "Deferred Deposit Lender," Utah Department of Financial Institutions, http://dfi.utah.gov/money-services/deferred-deposit-lender/; "UTAH CODE TITLE 7, CHAPTER 23, CHECK CASHING REGISTRATION ACT," Utah Department of Financial Institutions, 2007, http://www.le.utah.gov/interim/2007/pdf/00000783.pdf and http://paydayloanlegislation.com/utah.html.

81 "Population by Race / Ethnicity," West Valley City, http://www.wvc-ut.gov/761/Population-by-Race-Ethnicity.

82 "West Valley City, Utah," City-Data.com, http://www.city-data.com/city/West-Valley-City-Utah.html.

${ }^{83}$ Rosemary Winters, "Peterson to Step Down," Salt Lake Tribune, July 6, 2007, http://archive.sltrib.com/printfriendly.php?id=6310151\&itype=NGPSID.

${ }^{84}$ Google, "Population of West Valley City, Utah in 2000". https://www.google.com/search?q=population+of+west+valley+city+utah+in+2000\&ie=utf-8\&oe=utf-8.

${ }^{85}$ Bob Bernick Jr., "Powerful new lobbying team stepping up to plate in Utah," Deseret News, January 13, 1998 , http://www.deseretnews.com/article/607050/Powerful-new-lobbying-team-stepping-up-to-plate-inUtah.html?pg=all.

86 "West Valley Backs Off Plans to Curtail Number of Check Cashing Businesses," The Enterprise, Nov. 29, 1999. 
${ }^{87}$ In August 1999, the City of South Salt Lake passed an ordinance that set limits on check cashers (which, in the absence of a definition in the ordinance may have included payday lenders), pawn shops, tattoo parlors, and temporary employment/staff services. Under the rules, these facilities could not be located any closer to one another or to residential areas than 600 feet. In addition, the number of these businesses could not exceed one per every 5000 residents of the city. The city's population at the time was about 20,000 people. According to Chris Peterson, he was not aware of the South Salt Lake ordinance when he started his effort to get an ordinance passed in West Valley City. South Salt Lake City, Ordinance 1999-14, p. 7.

${ }^{88}$ Kingdon, Op Cit.

${ }^{89}$ Chris Peterson, "Failed Markets, Failing Government, or Both? Learning from the Unintended Consequences of Utah Consumer Credit Law on Vulnerable Debtors," Utah Law Review 534 (2001), 543. http://heinonline.org/HOL/Page?handle=hein.journals/utahlr2001\&div=18\&g sent=1\&collection=journals. ${ }^{90}$ Ibid., 563-4.

${ }^{91}$ Utah State Bar, "Only Until Payday: A Primer on Utah's Growing Deferred Deposit Loan Industry," Utah Bar Journal, March 7, 2002, https://www.utahbar.org/utah-bar-journal/article/only-until-payday-a-primer-on-utahsgrowing-deferred-deposit-loan-industry/.

${ }^{92}$ It is interesting here that there is a distinction between check cashing and payday lending, while in later ordinances and in our interviews, the two were often conflated.

${ }^{93}$ Minutes of the West Valley City Council, May 21, 2002, http://www.wvcut.gov/DocumentCenter/Home/View/569.

${ }_{94}$ Minutes of the West Valley City Planning Commission, July 10, 2002, http://www.wvcut.gov/DocumentCenter/View/1067.

${ }^{95}$ Minutes of the West Valley City Council, September 17, 2002, http://www.ci.westvalley.ut.us/DocumentCenter/Home/View/575.

${ }^{96}$ Nicole Cottle Interview, p. 36.

${ }^{97}$ Margaret Peterson Interview, p. 20.

${ }^{98}$ Ibid., 20.

${ }^{99}$ Lee Davidson, "Trapped for cash: Thriving in Utah: Payday loan stores are popping up everywhere," Deseret News, November 14, 2005, http://www.deseretnews.com/article/635161153/Thriving-in-Utah-Payday-loanstores-are-popping-up-everywhere.html?pg=all.

${ }^{100}$ Nicole Cottle Interview, p. 7.

101 Ibid., 4.

102 Ibid., 8.

${ }^{103}$ Margaret Peterson Interview, p. 27.

${ }^{104}$ Minutes of the West Jordan Planning and Zoning Commission, February 19, 2003, http://www.wjordan.com/files/02-19-2003.pdf.

${ }^{105}$ City of West Jordan, City Council Meeting Minutes, March 25, 2003.

${ }^{106}$ City of Taylorsville, Planning Commission Meeting Minutes, Tuesday, November 9, 2014.

${ }^{107}$ City of Taylorsville, City Council Meeting Minutes, Wednesday, December 15, 2004.

${ }^{108}$ City of Taylorsville, City Council Meeting Minutes, Wednesday, July 13, 2005. The ordinance, No. 05-40, included a 600-foot separation between lenders and a limit of one per 10,000 residents.

${ }^{109}$ Lee Davidson, Trapped for Cash, Deeper in Debt," Deseret News, November 13, 2005, http://www.deseretnews.com/article/635158738/Trapped-for-cash-Deeper-in-debt.html?pg=all; Lee Davidson, "Trapped for cash: Thriving in Utah: Payday loan stores are popping up everywhere," Deseret News, November 14, 2005, http://www.deseretnews.com/article/635161153/Thriving-in-Utah-Payday-loan-stores-are-popping-upeverywhere.html?pg=all; Lee Davidson, "Utah too lax on payday lenders? Businesses find friendly laws and financial allies here," Deseret News, November 15, 2005, http://www.deseretnews.com/article/635159502/Utahtoo-lax-on-payday-lenders.html?pg=all.

${ }^{110}$ Crossroads Urban Center, History of CORC, http://home.utah.edu/ u0371791/CUC/CORC.html\#History;

Glenden Brown, October 23, 2006, "Glen's Primer on Payday Lending in Utah," One Utah, blog,

http://www.oneutah.org/2006/10/glens-primer-on-payday-lending-in-utah/. 
${ }^{111}$ Lee Davidson, "Trapped for cash: Thriving in Utah," op. cit.

112 The cities were Draper, Midvale, Murray, Sandy, South Salt Lake, South Jordan, and West Jordan.

113 Derek P. Jensen, "Salt Lake City moves to curb payday lenders," Salt Lake Tribune, April 21, 2009, http://archive.sltrib.com/story.php?ref=/ci 12195704. At this point, critics of payday lending had raised their expectations and criticized the Salt Lake ordinance as weak. This article also cites the argument that caps lock in the turf of the existing lenders.

${ }^{114}$ Crossroads Urban Center, "Emergency Food Pantry," https://www.crossroadsurbancenter.org/emergency-foodpantry.html.

115 Linda Hilton Interview, p. 8.

116 Linda Hilton Interview, p. 9.

${ }^{117}$ Crossroads Urban Center, The Advocate, newsletter, Fall 2002.

118 In 2003, a bill passed that required lenders to accept partial payments and allow borrowers to rescind a loan by the next day. See: Crossroads Urban Center, The Advocate, newsletter, Spring 2003. In 2016, the state legislature passed what a payday lending industry representative called "the most consumer-friendly regulation in the country" but which consumer advocate Art Sutherland described to the authors of this report as a "regression" in terms of consumer protection. Lee Davidson, "Regulations for Utah Payday Loans Advance," The Salt Lake Tribune, February 16, 2016, http://www.sltrib.com/home/3544747-155/regulations-for-utah-payday-loans-advance; Lee Davidson, "New Payday Loan Regulations Receive Final OK," Salt Lake Tribune, March 9, 2016, http://www.sltrib.com/home/3640906-155/new-payday-loan-regulations-receive-final.

${ }^{119}$ Linda Hilton Interview, p. 14.

120 Ibid., 15.

121 Ibid., 17.

122 Ibid., Part 2, 4-5.

123 Ibid., 19-20.

${ }^{124}$ Laura Polachek, "MONEY Magazine Names AARP Utah Area Coordinator Art Sutherland as Utah's Money Hero," AARP Utah, July 9, 2014, http://states.aarp.org/money-magazine-names-aarp-utah-area-coordinator-artsutherland-as-utahs-money-hero-sc-ut-wp-money/.

${ }^{125}$ Midvale City, City Council Meeting Minutes, August 22, 2006.

126 "John Swallow," Wikipedia.com, https://en.wikipedia.org/wiki/John Swallow\#cite note-26.

${ }^{127}$ Robert Gehrke et al., "Swallow, Shurtleff arrested, face 23 counts, up to 30 years prison," Salt Lake Tribune, July 19, 2014, http://archive.sltrib.com/story.php?ref=/sltrib/news/58185969-78/swallow-shurtleff-utah-

general.html.csp.

${ }^{128}$ Rosemary Winters, "Sandy postpones vote on payday cash stores," Salt Lake Tribune, February 22, 2007, http://archive.sltrib.com/story.php?ref=/news/ci 5278737.

${ }^{129}$ Amelia Nielson-Stowell and Doug Smeath, "Sandy limits payday lenders," Deseret News, March 7, 2007, http://www.deseretnews.com/article/660201279/Sandy-limits-payday-lenders.html?pg=all.

${ }^{130}$ Leigh Dethman, "Payday Lenders Get Boot," Deseret News, May 21, 2008, http://www.deseretnews.com/article/700227808/Payday-lenders-get-boot.html?pg=all.

${ }^{131}$ Linda Hilton Interview, Part 2, pp. 2-3.

132 The ordinance localities are: Draper, Midvale, Murray, Salt Lake City, Sandy, South Salt Lake, South Jordan, Taylorsville, West Jordan, West Valley City, and Unincorporated Salt Lake County.

${ }^{133}$ Lee Davidson, "Fast growth of payday stores in Utah cools," Deseret News, October 7, 2008, http://www.deseretnews.com/article/700264675/Fast-growth-of-payday-stores-in-Utah-cools.html?pg=all.

${ }_{134}$ Nicole Cottle and Margaret Peterson Interview, p. 5.

${ }^{135}$ Google, "Population of West Valley City, Utah," https://www.google.com/search?q=population+of+West+Valley+City+Utah\&ie=utf-8\&oe=utf-8.

${ }^{136}$ Phillip Hill Interview, pp. 4-5.

${ }^{137}$ Art Sutherland Interview, Part 2, pp. 9-10.

${ }^{138}$ Christopher L. Peterson, Taming the Sharks: Towards a Cure for the High Cost Credit Market (Akron, OH: University of Akron Press, 2004). 
${ }^{139}$ Chris Peterson has juggled his work as a law professor with special assignments with the U.S. Consumer Financial Protection Bureau and U.S. Department of Defense.

${ }^{140}$ Chris Peterson Interview, pp. 13-14.

${ }^{141}$ Christopher L. Peterson, "'Warning: Predatory Lender' -A Proposal for Candid Predatory Small Loan

Ordinances," Washington and Lee Law Review, Vol. 69, No. 2 (Spring, 2012), pp. 893-978.

${ }^{142}$ Linda Hilton Interview, Part 2, p. 21.

${ }^{143}$ Brice Wallace, "Utah legislators consider action on payday lenders," Deseret News, May 17, 2007, http://www.deseretnews.com/article/660221280/Utah-legislators-consider-action-on-paydaylenders.html?pg=all; Lee Davidson, "Fines OK'd for payday lenders: But critics call SB16 too weak; they urge passage of HB329," Deseret News, January 28, 2007, http://www.deseretnews.com/article/655192023/Fines-OKdfor-payday-lenders.html?pg=all.

144 "About Silicon Valley Community Foundation," accessed Nov. 22, 2016, www.siliconvalleycf.org.

${ }^{145}$ Before this, Dr. Carson had a distinguished 12-year career as CEO of The Minneapolis Foundation and, prior to that oversaw the Ford Foundation's U.S. and global grant-making program on philanthropy and the nonprofit sector. He has published more than 100 works on philanthropy and is an authority on issues of social justice, public accountability and African American giving. He is consistently recognized as one of the most influential nonprofit leaders in the U.S. and has honorary degrees from Indiana University, Morehouse College and The National Hispanic University. He received both his master's and Ph.D. degrees in public and international affairs from Princeton University and his bachelor's degree in economics, Phi Beta Kappa, from Morehouse College. "Emmett D. Carson, Ph.D.," Silicon Valley Community Foundation, http://www.siliconvalleycf.org/emmett-d-carson-phd. 146 "Report of Independent Auditors and Consolidated Financial Statements," Silicon Valley Community Foundation, Dec. 31, 2015 and 2014, http://www.siliconvalleycf.org/sites/default/files/documents/financial/2015independent-auditors-report.pdf; and "History," Silicon Valley Community Foundation, accessed November 21, 2016, http://www.siliconvalleycf.org/history.

147 "Understanding the Limits on Lobbying by Grantmakers," NCNG Quarterly Newsletter, June 8, 2011, http://www.robinsonbradshaw.com/newsroom-publications-Understanding-the-Limits-on-Lobbying-by-

Grantmakers-06-08-2011.html; Bolder Advocacy, accessed Nov. 21, 2016, http://bolderadvocacy.org/wpcontent/uploads/2012/06/Advocacy and Community Foundations.pdf.

148 "A New Way Forward," Silicon Valley Community Foundation, accessed Nov. 21, 2016, http://www.siliconvalleycf.org/docs/yearInReview9 web2.pdf; Proceedings of Silicon Valley Community Foundation's Community Economic Development Strategic Conversation, September 27, 2007, http://www.siliconvalleycf.org/docs/cip/CEDproceedings final.pdf.

149 "Grant Foundation Executive Strategies," Silicon Valley Community Foundation, September 10, 2008, http://www.siliconvalleycf.org/grantmaking-strategies/pdf/executive-summary.pdf.

${ }^{150}$ Phone Conversation with Eleanor Clement Glass, September 25, 2015.

${ }^{151}$ Both of the parents were community foundations, so they were permitted to fund advocacy and engage in it themselves, but the parent foundations chose not to.

152 John Boudreau, "Mercury News Interview: Emmett Carson, CEO and president, Silicon Valley Community Foundation," The Mercury News, August 3, 2012, http://www.mercurynews.com/ci 21229599/mercury-newsinterview-emmett-carson-ceo-silicon-valley-community-foundation.

153 "Grantmaking Strategies: Research Paper on Asset Building and Financial Education," Silicon Valley Community Foundation, September 10, 2008, http://www.siliconvalleycf.org/grantmaking-strategies/pdf/research-paperasset-building.pdf, p. 3.

${ }^{154}$ Ibid., p. 5.

155 Ibid., p. 4.

156 Ibid., p. 6.

157 "RFP Archive," Silicon Valley Community Foundation, accessed November 21, 2016, http://www.siliconvalleycf.org/rfp-archive.

${ }^{158}$ In addition to national, state, and local government action, the study called for marketplace alternatives to payday loans as well as enhanced consumer education. 
159 "Grantmaking Strategies: Request for Proposals: Anti-Payday Lending Policy Advocacy," Silicon Valley Community Foundation, June 18, 2009, http://www.siliconvalleycf.org/grantmaking-strategies/pdf/anti-paydaylending.pdf.

${ }^{160}$ City Council of Oakland, California, Ordinance No. 12626, October 19, 2004.

${ }^{161}$ Press Release from the City and County of San Francisco, January 10, 2006, http://sftreasurer.org/ianuary-102006. A "fringe financial service" was defined in the final ordinance as "a retail use that provides banking services and products to the public and is owned or operated by a 'check casher' as defined in California Civil Code section 1789.31 as amended from time to time, or by a 'licensee' as defined in California Financial Code section 23001(d), as amended from time to time." http://www.sfbos.org/ftp/uploadedfiles/bdsupvrs/ordinances07/00269-07.pdf and http://planning.sanfranciscocode.org/2/249.35/.

162 “Fringe Financial Service Restricted Use District," San Francisco Decoded, City of San Francisco Planning, accessed November 21, 2016, http://planning.sanfranciscocode.org/2/249.35/.

${ }^{163}$ Sacramento City Council, Ordinance Number 2009-017, March 31, 2009, http://www.records.cityofsacramento.org/ViewDoc.aspx?ID=s6tFBnt4W+KvmG8S01loQ0IOosCCv6/w.

164 "Press Release: Treasurer Jose Cisneros and Supervisor Tom Ammiano introduce Ban on check-cashing and payday lending businesses in San Francisco," City and County of San Francisco, Office of the Treasurer, October 18, 2005, http://sftreasurer.org/october-18-2005.

165 "The Financial Divide: An Uneven Playing Field," California Reinvestment Coalition, March 2005, http://www.calreinvest.org/system/resources/W1siZilsljlwMTIvMDYvMTgvMTNfMjRfMzFfMTkxXOZpbmFuY2lhbF9 EaXZpZGVfYmFua19maW5hbmNpbmdfb2ZfY2h/Y2tfY2FzaGluZ19hbmRfcGF5ZGF5LnBkZiJdXQ/Financial\%20Divide\%20bank\%20financing\%20of\%20check\%20cashing\%20and\%20payday.pdf.

${ }^{166}$ Ibid, 3.

${ }^{167}$ Ibid, 9.

${ }^{168}$ Charisse Ma Lebron, "Payday Lenders Evade Regulations: A Summary of Findings from Surveying Payday Lending Establishments," California Reinvestment Coalition, March 21, 2007. http://www.calreinvest.org/system/resources/W1siZilsljlwMTIvMDYvMTgvMTRfNDhfNDJfODY1X3BheWRheV9ldm FkZV9yZWdzLnBkZiJdXQ/payday\%20evade\%20regs.pdf.

${ }^{169}$ Wei Li, et al., "Predatory Profiling: The Role of Race and Ethnicity in the Location of Payday Lenders in California," Center for Responsible Lending, March 26, 2009, http://responsiblelending.org/california/capayday/research-analysis/predatory-profiling-exec-summary.pdf; "Snapshot: Payday Lending in California," Center for Responsible Lending, accessed November 21, 2016.

http://www.responsiblelending.org/sites/default/files/nodes/files/research-publication/payday-fact-and-policysheet.pdf; "Payday Lending and the Debt Trap in California." Center For Responsible Lending. May 2009. http://www.responsiblelending.org/sites/default/files/nodes/files/research-publication/payday debt trap ca.pdf. ${ }^{170}$ The Insight Center received its grant under SVCF's first round of anti-payday lending advocacy, whereas the Pacifica Resource Center had grants from SVCF as part of its safety net and asset building programs. See: http://www.siliconvalleycf.org/grantees-list.

${ }^{171}$ Agenda for City Council of the City of Pacifica, meeting for January 24, 2011, http://www.cityofpacifica.org/civica/filebank/blobdload.asp?BlobID=4121.

${ }^{172}$ Camden Swita, "Pacifica's Payday Lender Problem," Pacifica Patch, October 13, 2010, http://patch.com/california/pacifica/pacificas-payday-problem. Recounting personal stories painstakingly gathered by social service organizations was a tactic we observed in other Silicon Valley jurisdictions and cities elsewhere such as Dallas and Denton, Texas.

173 "Request for Proposals, Economic Security Strategy: Anti-Payday Lending Policy Advocacy," Silicon Valley Community Foundation, November 17, 2010. http://www.siliconvalleycf.org/sites/default/files/rfp/AntiPayDay10 RFP.pdf, p. 3.

${ }^{174}$ City of East Palo Alto, Demographics, accessed November, 21, 2016, http://www.ci.east-paloalto.ca.us/index.aspx?nid=94. 
175 "Press Release: Silicon Valley Community Foundation Awards \$500,000 in Grants to Address Foreclosure Crisis," Silicon Valley Community Foundation, February 9, 2009, http://www.siliconvalleycf.org/press-release-february-92009.

$\frac{2009}{176}$ “Anti Payday Lending Grantees," Silicon Valley Community Foundation, accessed November 21, 2016, http://www.siliconvalleycf.org/anti-payday-lending-grantees-2011.

${ }^{177}$ Keith Ogden Interview, p. 11.

178 Pat Krackov Interview, p. 1.

${ }^{179}$ Community Legal Services in East Palo Alto, "U-Pay-Us: The Payday Lending Show," Filmed July 2011, Posted July 25, 2011, https://www.youtube.com/watch?v=0InXz14Uoi4.

${ }^{180}$ See Griffith et al., op cit.

${ }^{181}$ Email Correspondence with Keith Ogden, June 27, 2016.

${ }^{182}$ Henrietta J. Burroughs, “California Bank \& Trust is closing its East Palo Alto branch," East Palo Alto Today, May 31, 2011, http://www.epatoday.org/news/2011/may 2011/shutting its doors 1390.html.

183 Nozipo Wobogo, "EPA Council considers payday lending," East Palo Alto Today, October - November 2011, http://www.epatoday.org/oct nov_2011/oct nov_pgs 1 8.pdf.

${ }^{184}$ Agenda for the Planning Commission of the City of East Palo Alto, Planning Commission meeting on December 9, 2011, http://www.ci.east-palo-alto.ca.us/AgendaCenter/ViewFile/Agenda/158; Agenda for the Planning Commission of the City of East Palo Alto meeting on November 23, 2011, http://www.ci.east-paloalto.ca.us/AgendaCenter/ViewFile/Agenda/11282011-159.

${ }^{185}$ Keith Ogden Interview, pp. 17-18.

${ }^{186}$ Pacific Resource Center, accessed November 21, 2016, https://web.archive.org/web/20160317131437/http://pacresourcecenter.org/blog/?page id=1125.

187 "One: Innovation through philanthropy," Silicon Valley Community Foundation, Spring 2011, http://www.siliconvalleycf.org/one-innovation-through-philanthropy/spring-11/one-innovation-throughphilanthropy-spring-11.pdf.

${ }^{188}$ Action Minutes of the Revised Special Joint City Council/Redevelopment Agency Meeting, City of East Palo Alto, November 29, 2011, http://www.ci.east-palo-alto.ca.us/AgendaCenter/ViewFile/Minutes/11292011-743.

189 2006-2010 Census City of San Jose, CA, Bay Area Census, http://www.bayareacensus.ca.gov/cities/SanJose.htm.

190 "Median household income in the top 20 most populated U.S. cities in 2015 (in U.S. dollars)," The Statistics Portal, accessed November 21, 2016, http://www.statista.com/statistics/205609/median-household-income-inthe-top-20-most-populated-cities-in-the-us/.

${ }^{191}$ Lewis Lehe and Matthew Green, "Visualization: How San Francisco's Population Changes Throughout the Day," KQED News, January 27, 2016, http://ww2.kqed.org/lowdown/2014/01/10/how-city-populations-change/.

${ }^{192}$ Aaron Sankin, “America's Richest Cities: San Jose Tops List With Highest Median Household Income," Huffingtonpost.com, September 24, 2012, http://www.huffingtonpost.com/2012/09/24/americas-richestcities n 1910260.html; "Household Income in San Jose, California," Statistical Atlas, accessed November 21, 2016, http://statisticalatlas.com/place/California/San-Jose/Household-Income.

San Jose has more wage inequality than income inequality. While wage inequality considers the differences between salaries only, income inequality compares all income, including rents, royalties, and

dividends. http://www.citylab.com/work/2012/03/inequality-american-cities/861/.

193 "Inequality and Economic Security in Silicon Valley," California Budget \& Policy Center, May 2016, p. 2, available at http://calbudgetcenter.org/resources/inequality-economic-security-silicon-valley/.

194 Ibid., 4. The wealthiest households in Silicon Valley-the top 1\%-have enjoyed unparalleled prosperity in the last twenty-five years, pulling apart from the rest of the region's average household income since at least 1989. While success of the top $1 \%$ contributes to the region's overall economic growth, this growth masks the challenges low- and middle-income households experienced over the same period. While incomes generally have grown further apart over the past twenty-five years, incomes for the top 1\% in particular have seen explosive growth, resulting in some of the largest income disparities in California. Now income gaps between Silicon Valley's top 1\% 
of households and the bottom $99 \%$ are among the widest in California and significantly wider than they were a generation before. Ibid., 5.

195 Catherine New, "San Jose Passes Ordinance Cracking Down On Payday Lenders," The Huffington Post, May 17, 2012, http://www.huffingtonpost.com/2012/05/17/san-jose-payday-lenders n 1524462.html.

196 "Grantmaking Strategies, Research Paper on Asset Building and Financial Education," Silicon Valley Community Foundation, September 10, 2008, http://www.siliconvalleycf.org/grantmaking-strategies/pdf/research-paperasset-building.pdf.

${ }^{197}$ About the Law Foundation, Law Foundation of Silicon Valley, accessed November 21, 2016, http://www.lawfoundation.org/mission.html . Law Foundation enjoys brought based financial support from law firms, foundations, non-profit organizations, and individuals based in California. "Donors," Law Foundation of Silicon Valley, accessed November 21, 2016, http://www.lawfoundation.org/donors.html; Leslie Cook, Kyra Kazantzis, Melissa Morris, and James Zahradka, "Report on the Status of Payday Lending in California," Silicon Valley Community Foundation, October 2009, https://www.siliconvalleycf.org/docs/payday-lending-report.pdf. ${ }^{198}$ Kyra Kazantzis Interview, p. 3.

199 Press Release, Silicon Valley Community Foundation, October 15, 2009, http://www.siliconvalleycf.org/pressrelease-october-15-2009.

200 "Anti-Payday Lending Policy Advocacy-2009," Silicon Valley Community Foundation, accessed November 22, 2016, http://www.siliconvalleycf.org/anti-payday-lending-policy-advocacy.

${ }^{201}$ CAPP's core members were: Public Interest Law Firm (an arm of the Law Foundation of Silicon Valley), California Reinvestment Coalition, Asian Law Alliance, Alliance of Californians for Community Empowerment, Sacred Heart Community Service, Step Up/Catholic Charities, United Way, Sunnyvale Community Services, St. Joseph's Family Services, West Valley Community Services, and Working Partnerships USA. SeeL “About CAPP." Coalition Against Payday Predators, https://coalition-against-pay-day-predators.org/about-capp/.

202 Annual Report 2010-2011, Law Foundation of Silicon Valley, 2011, accessed November 22, 2016. http://lawfoundation.org/download/documents/LAW_208_AR 2011.pdf, p.30.

203 James Zahradka Interview, p. 5.

204 Law Raza Roundtable's Facebook page, accessed November 22, 2016, https://www.facebook.com/LaRazaRoundtable/info/?entry point=page nav about item\&ref=page internal. ${ }^{205}$ Kyra Kazantzis Interview, p. 18.

206 Ibid., 19.

207 The Fly, “Manny Diaz Shilling for Loan Sharks," San Jose Inside, Politics, April 27, 2011. http://www.sanjoseinside.com/2011/04/27/manny diaz predatory lending/.

208 "San Jose and Santa Clara County city leaders push for curbs on payday lending," Mercury News, April 24, 2012, Updated: August 13, 2016 at 4:58, http://www.mercurynews.com/ci 20470869/san-jose-and-santa-clara-countycity-leaders.

${ }^{209}$ David Rusk, Inside Game/Outside Game: Winning Strategies for Saving Urban America (Washington, DC: Brookings Institution Press, 1999).

${ }^{210}$ Christine A. DeGregorio, Networks of Champions: Leadership, Access, and Advocacy in the U.S. House of Representatives (Ann Arbor: University of Michigan Press, 1997); Christine Mahoney and Frank R. Baumgartner, "Partners in Advocacy: Lobbyists and Government Officials in Washington," The Journal of Politics, Volume 77, No. 1, 2015, pp. 202-15.

${ }^{211}$ Goodwin Simon Strategic Research, Key Findings from Payday Loan Users Focus Groups, op. cit.

212 Kyra Kazantzis Interview, p. 11. Framing by CAPP and SVCF grantees working outside Santa Clara County was facilitated by cohort meetings convened by SVCF that brought together grantees from across Silicon Valley. One such meeting involved a presentation on framing by the Lighthouse Collaborative.

http://www.lightboxcollaborative.com/.

${ }^{213}$ Goodwin Simon Strategic Research, San Jose Payday Loan Store Restrictions Survey, op. cit.

214 "Consumed by payday loans: State legislators offer haven for lenders deemed 'predatory'," Mercury News, October 30, 2011, Updated August 13, 2016 at 10:44 am. http://www.mercurynews.com/ci_19227617; 
http://www.pasadenastarnews.com/general-news/20111112/payday-loan-businesses-thrive-in-state-withassemblyman-charles-calderons-backing.

215 “Editorial: If state won't ban predatory lending, cities and counties must restrict it," Mercury News, October 29, 2011, http://www.mercurynews.com/opinion/ci 19218147; "Editorial: San Jose must cap number of payday lenders," Mercurynews.com, April 29, 2012, http://www.mercurynews.com/ci 20499732/mercury-news-editorialsan-jose-must-cap-number; Editorial: San Jose takes the lead against payday lending," Mercurynews.com, May 16, 2012.

216 "Editorial: San Jose must cap number of payday lenders," Mercury News, April 29, 2012, http://www.mercurynews.com/ci 20499732/mercury-news-editorial-san-jose-must-cap-number.

217 "Pacifica adopts interim ordinance prohibiting more payday lenders," Coalitionagainstpaydaypredators.org, December 21, 2010, https://coalition-against-pay-day-predators.org/category/blog-archives/page/26/.

${ }^{218}$ Kalra's chief of staff, Joseph Okpaku, was cited by ordinance supporters as both sympathetic and effective.

${ }^{219}$ A few months earlier, CAPP had begun its lobbying effort with respect to Santa Clara County, with the objective of enacting an ordinance covering the unincorporated parts of the county. For example, see: Ash Kalra and Xavier Campos, Memorandum to Mayor and City Council of the City of San Jose, December 9, 2010,

http://www3.sanjoseca.gov/clerk/CommitteeAgenda/Rules/20101215/rules20101215 h5.pdf, and Minutes of the Human Relations Commission of the Santa Clara County Board of Supervisors, November 18, 2010, http://sccgov.iqm2.com/Citizens/Detail Meeting.aspx?ID=1383.

${ }^{220}$ Memorandum to City of San Jose Mayor and City Council from Councilmembers Ash Kalra and Xavier Campos, December 9, 2010, http://www3.sanjoseca.gov/clerk/CommitteeAgenda/Rules/20101215/rules20101215 h5.pdf.

${ }^{221}$ Action Alert-San Jose Hearing, Coalitionagainstpaydaypredators.org, December 8, 2010, https://coalitionagainst-pay-day-predators.org/2010/12/08/committee-hearing-december-15th/.

222 "City Council takes important first steps," Coalitionagainstpaydaypredators.org, December 22, 2010, https://coalition-against-pay-day-predators.org/2010/12/22/city-council-takes-important-first-steps/.

${ }^{223}$ Mike Cassidy, "Silicon Valley starting to push back against payday lenders," Mercurynews.com, December 16, 2010, http://www.mercurynews.com/business/ci 16878521?nclick check=1.

${ }^{224}$ Memorandum to City of San Jose Mayor and City Council from City Clerk Dennis Hawkins, January 7, 2011, http://www3.sanjoseca.gov/clerk/CommitteeAgenda/Rules/20110112/rules20110112 f.pdf.

225 "Press Release: Community Foundation Awards $\$ 500,000$ Grants for Anti-Payday Lending Policy Advocacy," Silicon Valley Community Foundation, March 16, 2011, http://www.siliconvalleycf.org/press-release-march-162011.

${ }^{226}$ Memorandum to City of San Jose Mayor and City Council from Ed Shikada, April 13, 2011, https://www.piersystem.com/external/content/document/1914/1065503/1/04-14-11\%20CMO.PDF.

${ }^{227}$ The Fly, op. cit.

${ }^{228}$ Ash Kalra, "Payday Lending Reform," Sanjoseinside.com, May 13, 2011, http://www.sanjoseinside.com/2011/05/13/05 1311 payday lending reform/.

${ }^{229}$ City of San Jose Minutes of Regular Session of City Council meeting, August 30, 2011, http://www3.sanjoseca.gov/clerk/Agenda/20110830/20110830min.pdf.

${ }^{230}$ The other two issues were smoking in outdoor areas and "social hosting" (providing an environment where underage drinking takes place, regardless of who provides the alcohol).

${ }^{231}$ Christian Luna Interview, p. 2.

232 Ibid.

${ }^{233}$ Transcript of the City of San Jose Planning Commission Public Hearing, April 25, 2012, http://sanjose.granicus.com/DocumentViewer.php?file=sanjose $9 \mathrm{cfa} 70 \mathrm{c} 35 \mathrm{~d} 5 \mathrm{~d} 815 \mathrm{e} 317 \mathrm{fa} 6 \mathrm{~cd} 18 \mathrm{df2f72.pdf \& view=}$ 1, p. 18.

$\frac{1}{234}$ Ibid.

${ }^{235}$ Ibid., 37.

${ }^{236} \mathrm{Ibid} ., 38$.

${ }^{237}$ Two weeks earlier, the Santa Clara County Board of Supervisors banned lenders from incorporated areas of the county. The move was largely symbolic given that there was only one lender in those areas. A moratorium was 
passed by the Board of Supervisors in February and a final ordinance on May 1, 2012. "New County Ordinance to Limit Payday Lenders," Palo Alto Online, May 3, 2012, http://paloaltoonline.com/news/2012/05/03/new-countyordinance-to-limit-payday-lenders.

${ }^{238}$ Transcript of the City of San Jose Planning Commission Public Hearing, April 25, 2012, http://sanjose.granicus.com/DocumentViewer.php?file=sanjose 9cfa70c35d5d815e317fa6cd18df2f72.pdf\&view= 1 , p. 56.

${ }^{239}$ Kyra Kazantzis Interview, p. 24.

${ }^{240}$ Memorandum to City of San Jose Mayor and City Council from Planning Commission, April 30, 2012, http://www3.sanjoseca.gov/clerk/Agenda/20120515/20120515 1103.pdf, p. 98.

${ }^{241}$ http://www.siliconvalleycf.org/docs/svcf-year-end-report.pdf.

242 "California Money: Finding Alternatives to Payday Lending," Kqed.org, December 10, 2010, http://www.kqed.org/a/californiamoney/R201012210733.

${ }^{243}$ Coalition Against Payday Lenders Event by San Jose Peace and Justice Center, February 8, 2012, http://www.sanjosepeace.org/calendar_event.php?eid=20120203170509588.

${ }^{244}$ Ibid., 14.

${ }^{245}$ Memorandum to City of San Jose Mayor and City Council from Planning Commission, April 30, 2012, http://www3.sanjoseca.gov/clerk/Agenda/20120515/20120515 1103.pdf.

${ }^{246}$ Memorandum to City of San Jose Mayor and City Council from Joseph Horwedel, May 9, 2012, http://www3.sanjoseca.gov/clerk/Agenda/20120515/20120515 1103sup.pdf, p.2.

${ }^{247}$ Ibid., 3.

248 Ibid.

249 "Open and Public IV: A Guide to the Ralph Brown Act," League of California Cities, revised July 2010, https://www.cacities.org/Member-Engagement/Professional-Departments/City-Attorneys-

Department/Publications/Open-Public-IV -A-Guide-to-the-Ralph-M-Brown-Act-\%28.aspx.

${ }^{250}$ Minutes of City Council of San Jose meeting, May 15, 2012, https://www.sanjoseca.gov/DocumentCenter/View/17408.

${ }^{251}$ City of San Jose Ordinance 29089, June 5, 2012, http://www.sanjoseca.gov/DocumentCenter/View/6809 It appears that Nguyen, not Herrera, was absent. See page 17.

${ }^{252}$ Jennifer Wadsworth and Josh Koehn contributed, "Payday Politics," Metroactive.com, accessed November 21, 2016, http://www.metroactive.com/features/payday-loans-short-term-lenders-new-regulations2.html.

${ }^{253}$ Favianna Rodriguez Blog: “New Bus Ad Campaign Against Predatory Payday Loans," blog entry by Favianna Rodriguez, July 4, 2012, http://favianna.typepad.com/faviannacom art activism/2012/07/campaign-againstpredatory-payday-loan-industry.html; http://www.calreinvest.org/news/coalition-launches-bus-ad-campaign-todiscourage-payday-loan-usage-among-san-jose-residents.

${ }^{254}$ Profile of Youth Leadership Institute, accessed November 21, 2016 http://yli.org/wpcontent/uploads/2015/11/YLI-Profile-FY-15-16.pdf.

${ }^{255}$ The existence of these machines in casinos is even more amazing given that the high-cost loan industry justifies its existence by insisting that people need the loans for emergencies and basic necessities. Gamblers need the opposite-not loans but the ability to leave when the money is gone.

${ }^{256}$ Fahad Qurashi Interview, p. 2.

${ }^{257}$ The grant was to be shared with another organization, Mission SF (later MyPath), that worked on financial empowerment of youth in San Francisco.

${ }^{258}$ Anti-Payday Lending Grantees 2013, Silicon Valley Community Foundation, accessed November 21, 2016, http://www.siliconvalleycf.org/anti-payday-lending-grantees-2013.

${ }^{259}$ Fahad Qurashi Interview, p. 4.

${ }^{260}$ Tim Lohrentz, "The Net Impact of Payday Lending in the U.S.," Insight Center for Community Economic Development, March 2013, http://ww1.insightcced.org/uploads/assets/Net\%20Economic\%20Impact\%20of\%20Payday\%20Lending.pdf. ${ }^{261}$ Tim Lohrentz, "Tools for Advocates of Limiting Payday Lending," Insight Center for Community Economic Development, June 2013, http://ww1.insightcced.org/uploads/assets/paydaylending/plat.pdf. 
${ }^{262}$ Anti-Payday Lending Grantees 2011, Silicon Valley Community Foundation, accessed November 21, 2016, http://www.siliconvalleycf.org/anti-payday-lending-grantees-2011; and Anti-Payday Lending Grantees 2013, Silicon Valley Community Foundation, accessed November 21, 2016, http://www.siliconvalleycf.org/anti-paydaylending-grantees-2013. The inclusion in the report of illustrations involving Daly City was no coincidence; Lohrentz had been seeking an ordinance in Daly City for several years.

${ }^{263}$ Daly City is noted for its high Filipino population and has been called the Pinoy capital of the U.S. https://www.amazon.com/Pinoy-Capital-Filipino-American-History/dp/1592136656. Interestingly, Lohrentz' analysis revealed that census tracts with payday lenders had a lower percentage of Asian residents than tracts without payday lenders.

${ }^{264}$ See, e.g., Tim Goldsmith and Nathalie Martin, Interest Rate Caps, State Legislation, and Public Opinion: Does the Law Reflect the Public's Desires? 89 CHICAGO KENT L. REV. 15 (2013). Conducting the survey was also a form of youth development inasmuch as the young people had to learn the nuts and bolts of creating and carrying out a survey as well as interpreting its results.

${ }^{265}$ Agenda for City of Daly City Council Regular Meeting on September 9, 2013, http://sireweb.dalycity.org/sirepub/mtgviewer. aspx?meetid=466\&doctype=MINUTES.

${ }^{266}$ The School has become an annual event with students from the previous cohort training the next cohort of students. https://ylisanfrancisco.wordpress.com/2015/02/18/yli-invitation-to-the-3rd-annual-school-for-financialand-economic-justice/.

${ }^{267}$ Christa Bigue, "Youth Take a Stand on Payday Lending's Crippling Affect on Daly City," Pacifica Patch, September 9, 2013, http://patch.com/california/pacifica/youth-take-a-stand-on-payday-lendings-crippling-affecton-daly-city; and Brendan P. Bartholomew, "Payday Lenders Come Under Fire in Daly City," The Examiner, September 10, 2013, http://archives.sfexaminer.com/sanfrancisco/payday-lenders-come-under-fire-in-dalycity/Content?oid=2574602.

${ }^{268}$ Fahad Qurashi Interview, p. 6. Funding by SVCF also allowed YLI to offer youth to be paid a small wage for their work and also qualify for matching savings accounts after a certain amount of work. The proceeds of the savings account are supposed to be used for productive purposes, such as buying a laptop for school. This is another place where SVCF's support of YLI may have positive ramifications beyond payday lending ordinances.

${ }^{269}$ Simultaneously with efforts to persuade city policy makers, the YLI youth sought the support of local media. They main vehicle was a press release aimed at the Pacifica Tribune and San Mateo Daily Journal. The young people learned how to put together a press release, but local media showed little interest in it.

270 "Daly City Councilman Aims to Stop Payday Loan Businesses," 5Kpix, CBS SF Bay Area, May 8, 2011, http://sanfrancisco.cbslocal.com/2011/05/08/daly-city-councilman-aims-to-stop-payday-loan-businesses/; Michelle Durand, "Daly City Tries Once More to Regulate Payday Lending," The Daily Journal, July 12-13, 2014, https://www.scribd.com/document/233576575/07-12-14-edition.

${ }^{271}$ Karen de Sá, "Consumed by payday loans: State Legislators offer haven for lenders deemed 'predatory," Mercurynews.com, October 30, 2011, updated August 13, 2016, http://www.mercurynews.com/ci 19227617.

${ }^{272}$ Guingona was also more likely to empathize with payday borrowers give that he represented the portion of the city ("the East Side") where all of the payday stores were located.

${ }^{273}$ Canepa and Guingona ran against each other for county supervisor in the June 2016 primary, and both advanced to the general election. Canepa ultimately won. Austin Walsh, "Canepa Victor in District 5 Race," The Daily Journal (San Mateo, California), November 9, 2016, http://www.smdailyjournal.com/articles/Inews/2016-1109/canepa-victor-in-district-5-race-county-sales-tax-stays-in-place-as-voters-overwhelmingly-support-measurek/1776425171118.html.

${ }^{274}$ Michael Guingona Interview, p. 4.

275 Ibid., 7.

${ }^{276}$ Agenda for City of Daly City Planning Commission Special Meeting for June 4, 2014, http://sireweb.dalycity.org/sirepub/mtgviewer.aspx?meetid=587\&doctype=agenda\&itemid=13922.

${ }^{277}$ Agenda for City of Daly City Council Regular Meeting for July 14, 2014, http://sireweb.dalycity.org/sirepub/mtgviewer.aspx?meetid=591\&doctype=MINUTES. 
${ }^{278}$ Councilmember Guingona called it "legislation on the fly." Once Torres saw that an ordinance was going to pass, he wanted to be able to say that he was responsible for part of it. Michael Guingona Interview, p. 10.

${ }^{279}$ Agenda for City of Daly City Council Regular Meeting for August 11, 2014, http://sireweb.dalycity.org/sirepub/mtgviewer.aspx?meetid=593\&doctype=MINUTES.

${ }^{280}$ Fahad Qurashi Interview, p. 25.

${ }^{281}$ Angela Swartz, "South City restricts payday lenders: Youth group wanted more from the zoning amendment," The Daily Journal, October 24, 2014, http://www.smdailyjournal.com/articles/Inews/2014-10-24/south-cityrestricts-payday-lenders-youth-group-wanted-more-from-the-zoning-amendment/1776425132177.html.

${ }^{282}$ Fahad Qurashi Interview, p. 29.

${ }^{283}$ City of South San Francisco Staff Report to Mayor and City Council from Alex Greenwood, Director of Economic and Community Development, October 22, 2014, http://ci-ssf-

ca.granicus.com/MetaViewer. php?view id=3\&clip id=799\&meta id=58160.

${ }^{284}$ Qurasi shared stories from his own difficult past and explained how those experiences continue to fuel his current passion for his profession. Fahad Qurashi Interview, p. 29.

${ }^{285}$ Agenda for City of Berkeley Planning Commission Regular Meeting for April 15, 2015, http://www.ci.berkeley.ca.us/uploadedFiles/Planning and Development/Level 3 -

Commissions/Commission for_Planning/2015-04-15 AGENDA\%20PACKET-Combined.pdf.

${ }^{286}$ Erica Wood Interview.

${ }^{287}$ Commentary: Ann Baddour, "Why Texas' Small-Dollar Lending Market Matters," e-Perspectives of Federal Reserve Bank of Dallas, Vol. 12, Issue 2, 2012, available at https://www.dallasfed.org/microsites/cd/epersp/2012/2 2.cfm.

${ }^{288}$ The first such ordinances were zoning ordinances, enacted in Richardson and Mesquite in early January 2008.

Richardson: https://www.cor.net/modules/showdocument.aspx?documentid=301; Mesquite: http://apps.cityofmesquite.com/city secweb/ordinances/3932.pdf . These ordinances came after several in Salt Lake County as well as those in several San Francisco Bay Area cities, but before any in the Silicon Valley area.

${ }^{289}$ Walker Moore Interview, p. 40.

${ }^{290}$ City of Dallas Ordinance 28287, http://citysecretary.dallascityhall.com/resolutions/2011/06-22-11/111825.PDF.

${ }^{291}$ Example Ordinance Disclaimer, Texas Municipal League, http://www.tml.org/payday-example-ordinance, updated Apr. 27, 2016, last visited on July 17, 2016).

${ }^{292}$ "City Regulation of Payday and Auto Title Lenders," Texas Municipal League, http://www.tml.org/paydayupdates. While there are many definitions of a social movement, these definitions typically refer to a network of individuals and organizations sharing an interest in instigating social change (and, occasionally stopping it), facing opposition and having a collective identity. This general definition is consistent with classics in the field of social movements as well as textbooks. A recent textbook is Donatella della Porta and Mario Diani, Social Movements: An Introduction (Oxford: Blackwell Publishing, 2006).

${ }^{293}$ Robert W. Snarr, "No Cash 'til Payday: The Payday Lending Industry," Federal Reserve Bank of Philadelphia, First Quarter 2002, https://www.philadelphiafed.org/bank-resources/publications/compliance-corner/2002/firstquarter/q1cc1 02.

${ }^{294}$ Joe Mahon, "Banking on the Fringe," Federal Reserve Bank of Minneapolis, July 1, 2004, https://www.minneapolisfed.org/publications/fedgazette/banking-on-the-fringe.

295 Jean Ann Fox, "Unsafe and Unsound: Payday Lenders Hide Behind FDIC Bank Charters to Peddle Usury," Consumer Federation of America, March 30, 2004, http://www.consumerfed.org/pdfs/pdlrentabankreport.pdf and http://www.consumerfed.org/pdfs/paydayreport.pdf; http://www.occ.gov/static/news-issuances/newsreleases/2002/nr-occ-2002-85.pdf; "Rent-a-Bank Payday Lending," Uspirg.org, November 13, 2001, http://www.uspirg.org/reports/usp/rent-bank-payday-lending; "Guidelines for Payday Lending," Fdic.gov, November 2015, https://www.fdic.gov/news/news/financial/2005/fil1405a.html.

${ }^{296}$ Tex. Const. art. XVI, §11.

${ }^{297}$ Commentary: Ann Baddour, "Why Texas' Small-Dollar Lending Market Matters," e-Perspectives of Federal Reserve Bank of Dallas, Vol. 12, Issue 2, 2012, available at https://www.dallasfed. /org 
microsites/cd/epersp/2012/2 2.cfm; "A History of Texas Credit Service Organization Model," Pdlcapital.com, 2011 http://www.pdlcapital.com/cso.html; "Texas CAB-Texas CSO-Credit Access Business, Payday Loan Industry, accessed November 21, 2016, http://www.payday-loan-industry.com/texas-cso.html.

298 "Texas CAB-Texas CSO-Credit Access Business, Payday Loan Industry, accessed November 21, 2016, http://www.payday-loan-industry.com/texas-cso.html.

${ }^{299}$ Handbook, "Chapter One: Local Government in Texas," accessed November 21, 2016 http://www.tml.org/Handbook-M\&C/Chapter1.pdf.

${ }^{300}$ This does not mean that state lawmakers will not try to preempt local payday ordinances or that industry lawsuits will not argue that local action is preempted by the state. In 2013, a bill filed by State Senator John Carona would have imposed some restrictions on lenders but would have also preempted city regulations (other than zoning.) The bill did not pass, however. "Payday Lending Bill Enhanced in Senate, Maybe Too Much," Texas Municipal League, http://www.tml.org/legis updates/legis update042613a Payday Lending\%2520Bill. Similarly, the Consumer Service Alliance of Texas, a payday industry trade association, argued unsuccessfully in a lawsuit that the Dallas payday ordinance was preempted by state law. Jess Krochtengel, "Texas Court Won't Revive Fight Against Payday Loan Law," Law360, May 27, 2014, http://www.law360.com/articles/541547/texas-court-won-trevive-fight-against-payday-loan-law. See also: Olivia M. Peña, "Municipal Regulation of Payday \& Title Loans in Texas," Journal of Consumer \& Commercial Law 17:2 (2014), http://www.jtexconsumerlaw.com/V17N2/V17N2 Payday.pdf.

${ }^{301}$ Jimhightower.com, accessed November 21, 2016, http://jimhightower.com/; Patrick Svitek, "Perry Launches Populist Offensive Against Big Banks," Texastribune.org, July 29, 2015, https://www.texastribune.org/2015/07/29/perry-wall-street-reform-speech/.

${ }^{302}$ Rev. Gerald Britt Interview, p. 26.

${ }^{303}$ Josephine Lopez Paul Interview, pp. 30-31. As Walker Moore explained in his interview:

For me, you know, that's-I keep talking about it from a farming community, and organizing a wayI became really angry at the church for not doing anything. I saw, you know, community issues just getting tripped to shreds, and the church is just sitting there-especially the Baptist Church sitting there preaching hellfire and brimstone. And that pissed me off.

And so organizing it is a way about reclaiming faith, and actually putting, you know-let's actually do something, and not tell people they're damned and going to hell all the time. And you ask what did I draw from this? I started organizing in Waco, yet another hotbed of activism and things like that (p.31).

${ }^{305}$ The Coalition of Religious Communities that pressured for passage of payday ordinances in Utah was an interfaith group, but it was a two or three person operation. It lacked the clout and resources of the Anti-Poverty Coalition in Dallas.

${ }^{306}$ Walker Moore Interview, p. 11

${ }^{307}$ Ann Baddour Interview, p. 18

${ }^{308}$ Ms. Baddour described the end of the "rent-a-bank" era and the beginning of the use of the CSO model. Baddour Interview, pp. 4-5. According to Baddour:

In 2005, the FDIC adopted certain parameters that limited the ability of banks to use the "rent-abank model," they limited the time of indebtedness to three months, three months maximum indebtedness to a payday loan, or 90 days. As a result of that and in the 2005 legislative session, there was an attempt to pass a law that would have allowed payday lending at-I can't remember; it was 15 or 17 on 100. At the same time, a perfect storm that happened. We had the FDIC regulations coming down that restricted the partnerships-or put rules around the partnerships with banks that the payday lenders did not want to comply with; we had a bill that would've enabled payday lending in its very traditional, typical business model to operate, and that bill failed; and in 2004, there was a Fifth Circuit Court decision called Lovick v. Ritemoney Ltd. That found that using the Credit Services 
Organizations act as a means to offer payday to broker-essentially, broker payday and auto title loans with unlimited fees, left those loans outside the usury cap. The interest rate was capped at $10 \%$, which is our usury cap, and these fees, were uncapped (pp. 4-5).

For a full description of the complexities of the law surround his issue, see https://www.dallasfed.org/microsites/cd/epersp/2012/2 2.cfm, last visited on August 11, 2016.

${ }^{309}$ Ann Baddour Interview, p. 19.

310 Jerry Allen Interview, p. 12.

${ }^{311}$ ACE Cash Express Donates $\$ 106,280$ to American Red Cross at Dallas City Hall, June16, 2010, http://www.prnewswire.com/news-releases/ace-cash-express-donates-106280-to-american-red-cross-at-dallascity-hall-96502344.html; Ace Cash Express' Facebook page, accessed November 21, 2016, video here: https://www.facebook.com/acecashexpress/videos/vb.286518770410/457532704950/?type=2\&theater. 312 Jerry Allen Interview, p. 6.

${ }^{313}$ See, for example, Rudolph Bush, "Before he slammed Rawlings as 'payday loan king,' Dallas Mayor Caraway praised ACE Cash Express," Dallas Morning News, April 25, 2001, http://www.dallasnews.com/news/politics/localpolitics/20110425-before-he-slammed-rawlings-as-payday-loan-king-dallas-mayor-caraway-praised-ace-cashexpress.ece. This article describes the Ace Cash Express City Council award that so inflamed Jerry Allen as follows:

Mayor Dwaine Caraway took a hard swipe last week at mayoral candidate Mike Rawlings for his long tenure on the board of the payday lending firm ACE Cash Express Inc.

But Caraway, who isn't running for mayor, failed to mention in two radio spots that he once had a much different view of the company that pushes fee- and interest-laden short-term loans across North Texas and in some of the poorest parts of Dallas.

Less than a year ago, Caraway joined council member Carolyn Davis in sponsoring a city proclamation praising Irving-based ACE for donating funds to earthquake relief efforts in Haiti. The June 2010 proclamation was delivered on the very morning that council member Jerry Allen planned to unveil the "Bank on Dallas" program aimed at educating low-income residents about the potential dangers of payday lending.

In the radio ad that aired Friday, Caraway spoke in a voice dripping with disgust, calling Rawlings the "payday loan king" and "the creator of payday loans."

"How can we support the payday loan king for mayor of Dallas?" he wondered.

But during a City Council meeting last year, Caraway praised ACE for what he called convenient services, adding that he hoped to see the company expand even further into Dallas neighborhoods.

314 "Short-term Cash, Long-term Debt: The Impact of Unregulated Lending in Texas," Texas Appleseed, accessed November 1, 2016, http://www.texasfairlending.org/wp/wp-content/uploads/2013/01/1242748734 A-Survey-ofPayday-Borrowers-April-2009-small.pdf.

${ }^{315}$ Hernan, Rozemberg, "Payday Loan Shops Exploit a Loophole," AARP Bulletin, Apr. 1, 2010, http://www.aarp.org/money/credit-loans-debt/info-04-2010/texas payday loan shops.html; Brendan Case, "AARP, Others seek tighter rules on payday loans in Texas," Dallasnews.com, July 2010, http://www.dallasnews.com/business/personal-finance/headlines/20100724-aarp-others-seek-tighter-rules-onpayday-loans-in-texas.ece.

${ }^{316}$ Rebecca Lightsy, “High-Cost Lenders Profit from Desperate Times," Dallas Morning News, February 16, 2010; "Payday Lenders Offer Instant Cash-But It Will Cost You," Dallas Morning News, April 26, 2009.

317 "Stop Predatory Lending in Dallas," accessed November 1, 2016, http://unway.3cdn.net/3042d62a5e53c9c3d9 5qm6ivdy9.pdf.

${ }_{318}$ Rev. Gerald Britt Interview, p. 54.

${ }^{319}$ Susan Williams Interview, p. 1. 
320 "Short-term Loan, Long-term Debt: The Impact of Unregulated Tending in Texas," Texas Appleseed, accessed September 9, 2016, https://www.texasappleseed.net/sites/default/files/94-PDLSurveyofPaydayBorrowers2009.pdf t 14.

${ }^{321}$ Susan Williams, Interview, p. 47. The Texas Office of Consumer Credit Commissioner also began publishing quarterly and annual data reports in 2012, which Texas Appleseed then took and created two-page data summary sheets that look at the cost of the loans, which products had more volume, and a rough picture of where the Texas market was going. The Texas Appleseed web site was also helpful as it contained numerous examples of the economic analysis of the Texas payday loan industry, including data on potential economic harm payday lending causes to communities. The Pew Charitable Trust had also done an analysis of Texas loans' pricing and competition, describing how and why there is really no meaningful price competition in this market, all of which was useful to the AARP.

322 Marc Jacobsen Interview, pp. 4 - 5.

${ }^{323}$ Stephanie Mace Interview, p. 2. Not all interviewees framed the genesis of the problem in terms of charities and churches paying for payday loans. Danielle Ayers of the South Dallas African American Friendship Baptist Church framed her concerns over payday lending in much broader terms, framing the problem in terms of basic fairness and justice. While Stephanie Mace, Katie Murray and many others shared that congregants were beginning to realize that they were subsidizing the payday lending industry, when asked if subsidizing the industry was a concern, Ms. Ayers said:

We'd never quite put it that way when we talk about the payday industry. We talk about how they have an unjust way of doing business. That's kind of how-that's our land and our kind of narrative, [describing] this access and what it does to families and homes, and communities, really. ... when the economy breaks down in the community, it impacts a lot of areas. You know, how many bad things your kids need school. I mean, it just-it snowballs. So, that's kind of how we do our narrative. It's more of a-this is just an unjust practice, business.

Danielle Ayers Interview, p. 16.

${ }^{324}$ The JCRC is the public affairs division of the Jewish Federation of Greater Dallas the public affairs division of the Jewish Federation of Greater Dallas. Jewish Federation of Greater Dallas, https://jewishdallas.org/jcrc/about-us. Its mission includes community outreach and legislative relations through a variety of interfaith, social action and Israel initiatives. It cultivates relationships to increase cultural understanding and to enact positive and progressive change in the greater Dallas area, and in keeping with the Jewish concept of Tikkun Olam or repairing the world, it became a founding member of the Anti-Poverty Coalition of Greater Dallas, which "brings together a number of area organizations to improve the financial health of our communities. One such project focuses on combating predatory payday lending practices in low-income neighborhoods." Ibid. CitySqure's mission and core values, are to fight the causes and effects of poverty through service, advocacy, and friendship, to change the trajectory of peoples' lives, and as a community of neighbors, and to investing in each other and develop meaningful relationships, and to use faith and justice to demand equality for all our neighbors. CitySquare's belief is that community resources belong to the community and that as stewards of those resources it should will act with integrity, demonstrate accountability and operate efficiently and effectively. http://www.citysquare.org/about/. Other non-profit organizations were also telling the United Way that payday lending was a problem. The United Way was able to get stories from grantees' clients. Eventually the problem became significant enough that even these direct service providers felt comfortable advocating and standing up against these loans, rather than just providing services.

${ }^{325}$ Susan Williams Interview, p. 6.

${ }^{326}$ Clickers are mechanical hand-held devices that allow student or participants in meetings to speak or vote electronically, and allow the votes to be received simultaneously by the teacher or leader.

${ }^{327}$ Marc Jacobsen Interview, p. 6.

${ }^{328}$ Rev. Gerald Britt Interview, p. 14. See also video at https://www.youtube.com/watch?v=KY4YP3nw05c, accessed December 10, 2016.

${ }^{329}$ Rev. Gerald Britt Interview, p. 18.

330 Ibid., 26. 
${ }^{331}$ Gerald Britt, Thursday, May 26, 2001 (5:00 a.m.), "VICTORY! Dallas City Council Unanimously Passes Zoning Ordinance to Regulate Payday Lenders," Change the Wind, http://www.changethewind.org/2011/05/victorydallas-city-council-unanimously.html.

332 Marc Jacobsen Interview, p. 8.

${ }^{333}$ Danielle Ayers Interview, p. 17.

334 Ibid., 19.

335 Ibid., 11.

${ }^{336}$ The largest of these churches are Antioch, Concord, Inspiring Body of Christ, and Oak Cliff Bible Fellowship. Danielle Ayers Interview, p. 1.

337 Ibid., 29.

338 Ibid., 12.

339 Ibid., 14

340 lbid., 17.

341 Ibid., 19.

342 Ibid., 32.

${ }^{343}$ Jeff Brumley, "Covenant of action inspires churches to social justice," Baptistnews.com, April 22, 2016, https://baptistnews.com/article/c/.

344 "A Call for Fair Lending Practices," Texas Catholic Conference of Bishops, https://txcatholic.org/pay-daylending/.

345 "2010 Catholic Charities Survey on Payday and Auto Title Loan Use," Texas Catholic Conference and the Center for Health and Social Policy, LBJ School of Public Affairs, February 2010, http://www.senate.state.tx.us/75r/Senate/commit/c510/handouts11/0223-BishopJoeVasquez.pdf.

346 "What Are Payday Loans (CABS)?," Texas Catholics for Fair-Lending, http://www.txcatholic-fairlending.org/; Mary Rezac, "How the Catholic Church is Fighting Loan Sharks in Texas," National Catholic Register, October 8 , 2015, http://www.ncregister.com/daily-news/how-the-catholic-church-is-fighting-loan-sharks-in-texas.

${ }^{347}$ The other was and remains Ft. Worth, where another large payday lender, Cash America, is located. Walker Moore Interview, p. 3.

${ }^{348}$ Robert Cadwallar, "Arlington eyes restrictions on payday lenders, car title loan businesses," Star-telegram.com, June 19, 2015, http://www.star-telegram.com/news/local/community/arlington/article24978919.html.

${ }^{349}$ Mary Rezac, "How the Catholic church is fighting loan sharks in Texas," Catholic News Agency, October 9, 2015, http://www.northtexascatholic.org/local-news-article?r=15VLNH2AMM.

350 "North Texas IAF Takes on Payday Lenders w/TX Catholic Conference," Dallas Morning News, October 2, 2015, http://webcache.googleusercontent.com/search?q=cache:yxzFwAr7hjUJ:www.industrialareasfoundation.org/cont ent/north-texas-iaf-takes-payday-lenders-w-tx-catholic-conference+\&cd=1\&hl=en\&ct=clnk\&gl=us.

${ }^{351}$ Patrick M. Walker, "Arlington is First in Tarrant to Regulate Payday, Auto Title Loans," Fort Worth StarTelegram, November 17, 2015, http://www.startelegram.com/news/local/community/arlington/article45282729.html. ${ }^{352}$ Gerald Britt, "Gerald Britt: How Rep. Hensarling's plan will strip Wall Street," Dallas Morning News, June 16, 2016, http://www.dallasnews.com/opinion/latest-columns/20160616-gerald-britt-how-rep.-hensarlings-plan-willstrip-wall-street-oversight.ece; "Gerald Britt: Is post-office banking an alternative to payday lending?," Dallas Morning News, February 13, 2014, http://www.dallasnews.com/opinion/latest-columns/20140210-is-post-officebanking-an-alternative-to-payday-lending.ece, last visited on August 10, 2016; Gerald Britt, "Gerald Britt: Payday Operations victimize the vulnerable," Dallas Morning News, October 19, 2011, http://www.dallasnews.com/opinion/north-south-dallas-project/viewpoints/grand-south-dallas/20111018-geraldbritt-payday-operations-victimize-the-vulnerable.ece; Gerald Britt, “Gerald Britt: Grass-roots citizens' hard work leads to payday loan regulations," Dallas Morning News, June 3, 2011, http://www.dallasnews.com/opinion/north-south-dallas-project/viewpoints/20110603-gerald-britt-grass-rootscitizens-hard-work-leads-to-payday-loan-regulations-.ece; Gerald Britt, "Gerald Britt: What southern Dallas churches can do to fight payday loans trouble," Dallas Morning News, November 26, 2010, 
http://www.dallasnews.com/opinion/latest-columns/20101028-Gerald-Britt-Jr-What-5873.ece, last visited on August 10, 2016.

${ }^{353}$ See, e.g., Gerald Britt, "Gerald Britt: Grass-roots citizens' hard work leads to payday loan regulations," Dallas Morning News, June 3, 2011, http://www.dallasnews.com/opinion/north-south-dallas-

project/viewpoints/20110603-gerald-britt-grass-roots-citizens-hard-work-leads-to-payday-loan-regulations-.ece, last visited on August 10, 2016; Gerald Britt, "Gerald Britt: What southern Dallas churches can do to fight payday loans trouble," Dallas Morning News, November 26, 2010, http://www.dallasnews.com/opinion/latestcolumns/20101028-Gerald-Britt-Jr-What-5873.ece.

354 "Top 10 Daily Newspapers in Texas," Cision.com, July 16, 2014, http://www.cision.com/us/2014/07/top-10daily-newspapers-in-texas/.

${ }^{355}$ Frank Tejo, "Worried about its image, Mesquite limits where payday lenders can open," Dallas Morning News, March 2, 2008, http://webcache.googleusercontent.com/search?q=cache:iB TS8JKNr8J:shapleigh.org/news/1564worried-about-its-image-mesquite-limits-where-payday-lenders-can-open+\&cd=3\&hl=en\&ct=clnk\&gl=us.

${ }^{356}$ Ken Kalthoff, "Dallas City Council Passes Strict Rules for Payday Lenders," Nbcdfdw.com, June 22, 2011, http://www.nbcdfw.com/news/local/Dallas-City-Council-Passes-Strict-Rules-for-Payday-Lenders--124390789.html. 357 Ibid.

358 Ibid.

${ }^{359}$ Consumer Serv. Alliance of Texas Inc., v. City of Dallas, No. 11-08739-A (14 ${ }^{\text {th }}$ Jud. Dist. Ct., Dallas County, Tex. Feb. 5, 2013), http://www.Irl.state.tx.us/scanned/archive/2011/16232.pdf. http://www.tml.org/p/130255opinion.pdf

${ }^{360}$ List of pleadings from each city's lawsuit, Texas Municipal League, accessed November 21, 2016, http://www.tml.org/payday-lawsuit-pleadings.

${ }^{361}$ Mitchell Schnurman, "Payday-loan industry spreads the money in Texas," Dallas News, April 2015, http://www.dallasnews.com/business/business/2015/04/06/payday-loan-industry-spreads-the-money-in-texas; Melissa Del Bosque, "Payday Loans Hearing: Lenders in Lobby-Land," Texasobserver.org, February 22, 2011, https://www.texasobserver.org/its-payday-lenders-and-lobby-land-in-senate-hearing/; "Loan-Shark-Financed Campaigns Threaten Payday Loan Reform," Texans for Public Justice, March 2011, http://info.tpj.org/reports/pdf/PaydayReport.mar2011.pdf.

362 “Dallas Payday Loan Ordinance," National League of Cities, accessed November 21, 2016, http://www.nlc.org/find-city-solutions/city-solutions-and-applied-research/city-practice-database/dallas-paydayloan-ordinance.

${ }^{363}$ City of Dallas Council Committee Briefings, accessed November 21, 2016, http://dallascityhall.com/government/Pages/Committee-Meetings.aspx.

${ }^{364}$ Meeting record of City of Dallas Council Committee on December 13, 2010, http://www3.dallascityhall.com/committee briefings/briefings0111/QOL minutes-121310 012411.pdf.

${ }^{365}$ Minutes of the Anti-Poverty Coalition of Greater Dallas, February 17, 2011.

${ }^{366}$ Walker Moore Interview, p. 19.

367 Ibid., 20.

${ }^{368}$ Rev. Gerald Britt Interview, p. 48.

${ }^{369}$ Anti-Poverty Coalition of Greater Dallas, accessed November 21, 2016, http://www.dallasfightspoverty.org/about-us/.

${ }^{370}$ See flyer at http://mymoneydfw.com/wp-content/uploads/2015/04/Payday-Lending-Alternatives.pdf.

${ }^{371}$ Minutes for City of Dallas Plan Commission, January 20, 2011, http://dallascityhall.com/government/meetings/DCH\%20Documents/plancommission/cpc minutes 012011 corrected.pdf.

372 Minutes for City of Dallas Plan Commission, February 3, 2011, http://dallascityhall.com/government/meetings/DCH\%20Documents/plan-commission/cpc minutes 020311.pdf. ${ }^{373}$ Minutes of City of Dallas City Council for February 9, 2011, http://citysecretary.dallascityhall.com/pdf/CC2011/cc020911.pdf. 
${ }^{374}$ Pastor Frederick Haynes, III, of Friendship-West Baptist Church also provided testimony to the Senate committee. https://www.youtube.com/watch?v=aBEf12oSelU.

${ }^{375}$ https://www.youtube.com/watch?v=Ir6shy3bsTw.

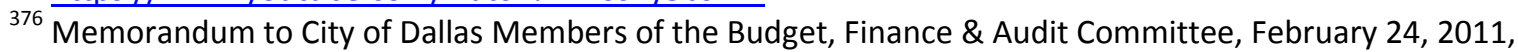
http://www3.dallascityhall.com/committee briefings/briefings0211/BFA \%20AlternativeFinancialEstablishment 0 22811.pdf; Meeting record of City of Dallas Budget, Finance \& Audit Committee for February 28, 2011, http://www3.dallascityhall.com/committee briefings/briefings0411/BFA Minutes022811 042511.pdf.

${ }^{377}$ Melissa del Bosque, "Payday Reform" Could it Finally Pass" Texas Observer, May 20, 2011, https://www.texasobserver.org/payday-reform-could-it-finally-pass/: "Editorial: Local and State Officials Must Act Now to Fox Payday Lending," Dallas Morning News, April 28, 2011, http://www.austintexas.gov/edims/document.cfm?id=169424..

${ }^{378}$ The strictest bill of all was introduced in the Texas Senate by Senators Wendy Davis and Royce West. Senate Bill 1862 would have capped fees and interest on loans made by payday and car title lenders. It met with fierce industry opposition and did not make it to a floor discussion or vote. Kelly Shannon, "Payday Lending Bills Get Senate Approval,' Dallas Morning News, May 23, 2011.

${ }^{379}$ Robert Wilonsky, "New Anti-Poverty Coalition to Demand Dallas City Hall Zone Payday Lenders Out of Business," Dallas Observer, April 12, 2011, http://www.dallasobserver.com/news/new-anti-poverty-coalition-todemand-dallas-city-hall-zone-payday-lenders-out-of-business-7114637.

${ }^{380}$ Minutes of the City of Dallas City Council for April 13, 2011, http://citysecretary.dallascityhall.com/pdf/CC2011/cc041311.pdf.

${ }^{381}$ At the time, city manager Mary Sumes was neither supportive nor against it, since the main concern of people in this position is economic impact. Later she supported the ordinance.

${ }^{382}$ Memorandum from City of Dallas Assistant City Manager to Budget, Finance \& Audit Committee, April 22, 2011, http://www3.dallascityhall.com/committee briefings/briefings0411/BFA AlternativeFinancialEstablishment 0425 11.pdf.

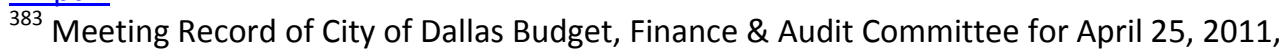
http://www3.dallascityhall.com/committee briefings/briefings0511/BFA minutes042511 052311.pdf.

384 "Editorial: "Local and state officials must act now to fix payday lending," Dallas News, April 2011, http://www.dallasnews.com/opinion/editorials/2011/04/28/editorial-local-and-state-officials-must-act-now-to-fixpayday-lending.

${ }^{385}$ Gromer Jeffers, Jr., "Dallas Mayor Dwaine Caraway blasts Mike Rawlings for serving on board of payday loan company," Dallas News, April 2011, http://www.dallasnews.com/news/local-politics/2011/04/22/dallas-mayordwaine-caraway-blasts-mike-rawlings-for-serving-on-board-of-payday-loan-company.

${ }^{386}$ The person who finished second in the race, retired Dallas police chief David Kunkle, probably would have been even worse from the perspective of payday reform. His consulting firm had produced a pro-payday lending study in 2010. https://dallascityhall.com/government/meetings/DCH\%20Documents/plancommission/cpc agenda 012011.pdf.

${ }^{387}$ See flyer at http://mymoneydfw.com/wp-content/uploads/2015/04/Payday-Lending-Alternatives.pdf. Stephanie Mace of the United Way did not know how much difference the postcards made in the City Council, but the postcard-gathering effort strengthened the resolve of APC's members. She told us: "At every community fair we could think of, we set up a table and said, 'Come sign one of these postcards.' Then people started saying things like, 'Oh, Yeah. That happened to my uncle,' or, 'Something happened to me,' and so it was really interesting the way it builds." Mace Interview, p. 31.

${ }^{388}$ Minutes of the Dallas City Council Meeting from May 25, 2011, http://citysecretary.dallascityhall.com/pdf/CC2011/cc052511.pdf.

${ }^{389}$ The industry also failed to speak at the subsequent city council hearing on the regulatory ordinance. According to Susan Williams of the AARP, industry attends every hearing on payday lending but does not speak at any of them. Williams Interview, p. 37. Industry does everything behind closed doors. Ibid.

${ }^{390}$ Minutes of the Dallas City Council Meeting from May 25, 2011 http://citysecretary.dallascityhall.com/pdf/CC2011/cc052511.pdf. 
${ }^{391}$ The Texas Legislature formally adjourned on May 30, but a special session began the next day. Consideration of payday lending was not on the agenda for the special session.

${ }^{392}$ http://www.capitol.state.tx.us/tlodocs/82R/billtext/pdf/HB02593I.pdf\#navpanes=0.

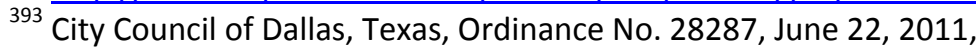
http://citysecretary.dallascityhall.com/resolutions/2011/06-22-11/11-1825.PDF.

${ }^{394}$ Minutes of the Dallas City Council Meeting from June 22, 2011, http://citysecretary.dallascityhall.com/pdf/CC2011/cc062211.pdf.

${ }^{395}$ Pleadings from Lawsuits Brought Against Payday Ordinances in Texas Cities, Texas Municipal League, http://www.tml.org/payday-lawsuit-pleadings.

${ }^{396}$ City Regulation of Payday and Auto Title Lenders, Texas Municipal League, http://www.tml.org/payday-update. ${ }^{397}$ Ibid.

398 Jerry Allen Interview, p. 14.

${ }^{399}$ Ibid., 14.

${ }^{400}$ Ibid., 16.

401 Ibid., 18

402 "Example Ordinance Disclaimer," Texas Municipal League, http://www.tml.org/payday-example-ordinance.

${ }^{403}$ The Municipal League is organized as a 501(c)(4).

https://projects.propublica.org/nonprofits/organizations/746000125.

${ }^{\overline{404}}$ History, Texas Municipal League, accessed 11/21/2016, http://www.tml.org/history.

${ }^{405}$ Example Ordinance Disclaimer, Texas Municipal League, accessed 11/21/2016, http://www.tml.org/paydayexample-ordinance.

$\frac{}{406} \mathrm{Ibid}$

${ }^{407}$ List of pleadings from each city's lawsuit, Texas Municipal League, accessed November 21, 2016, http://www.tml.org/payday-lawsuit-pleadings.

${ }_{408}$ Pat Smith Inteview, p. 1. See also: Paul Kiel, "To Dodge Law, High-Cost Lender Offers Cash for Free," Propublica.org, September 3, 2013, 1:09 p.m., https://www.propublica.org/article/high-cost-lender-offers-cashfor-free-to-dodge-law; Peggy Heinkel-Wolfe; "Group Informs Council of Issue," Denton Record-Chronicle, January 1, 2013, 8:52 PM, http://www.dentonrc.com/local-news/local-news-headlines/20130101-group-informs-council-ofissue.ece; Britney Tabor and Megan Gray, "Groups Try to Reform Loan Practices," Denton Record-Chronicle, March 18, 2013, 11:28 PM, http://www.dentonrc.com/local-news/local-news-headlines/20130318-groups-try-to-reform-loan-practices.ece.

${ }^{409}$ Missionwaco.org, accessed November 21, 2016, http://missionwaco.org/mission-waco/.

${ }^{410}$ Suzii Paynter, "The Politics of Poverty Presentation, October $19^{\text {th }}, 2012$, http://rodenfordenton.com/wp/wp-content/uploads/2012/12/Predatory Lending Handout1.pdf Paynter also testified before the state legislature in February, 2011, on payday lending. See: http://tbmaston.blogspot.com/2011/02/testimony-by-suzii-paynter-on-payday $25 . \mathrm{html}$

${ }^{411}$ This was not the first time that Strader had aligned her faith-based beliefs and actions. During graduate school, she and several other people from her church moved into Section 8 subsidized housing to improve their ability to work with residents there. She explained: "We could go and do outreach, we could go and play kickball with the kids, but no one would ever trust us because we were in their eyes rich, wealthy people, coming in to do benevolence or charity. And so we moved in to really become their friends and to learn from them, to share back and forth with them, ultimately with the hope of sharing the Gospel with them. And so I lived there as a missionary for eleven months until I got married, and then my husband and I decided not to live there. It's a hard place to live. But that really opened my eyes. I grew up on a farm, and so it really opened my eyes to the issues of poverty."

Kayce Strader Interview, pp. 58-59.

${ }^{412}$ Ibid., 5.

${ }^{413}$ Pat Smith, Interview, p. 5.

${ }^{414}$ Ibid., 23.

${ }^{415}$ Ibid., 10. 
${ }^{416}$ Handout Denton Predatory Lending, accessed November 21, 2016, http://rodenfordenton.com/wp/wpcontent/uploads/2012/12/Predatory_Lending_Handout1.pdf.

${ }^{417}$ Heinkel-Wolfe, op. cit.

${ }^{418}$ Joe Ader, Denton for Fair Lending, Prezi Presentation, December 19, 2012, https://prezi.com/olv59pdroaoi/predatory-lending/?auth key=963d15c2de96c40551957de263bbaceafbbe5c6e. ${ }^{419}$ Pat Smith Interview, p. 13.

${ }^{420}$ City of Denton City Council Agenda for January 15, 2013, http://dentontx.granicus.com/MediaPlayer.php?view id=3\&clip id=711\&meta id=51236.

${ }^{421}$ Tim Lorentz, "The Net Economic Impact of Payday Lending in the U.S.," Insight Center for Community Economic Development, March 2013, http://ww1.insightcced.org/uploads/assets/Net\%20Economic\%20Impact\%20of\%20Payday\%20Lending.pdf.

${ }^{422}$ Kayce Strader, Interview, p. 7.

${ }^{423}$ Ibid., 7.

${ }^{424}$ Ibid., See also: Britney Tabor and Megan Gray, "Consumers Who Use Short-Term Lenders Can Be Stuck in Cycle of Debt," Denton Record-Chronicle, March 18, 2013, http://www.dentonrc.com/local-news/local-news-

headlines/20130318-groups-try-to-reform-loan-practices.ece.

${ }^{425}$ Pat Smith Interview, p. 8.

${ }^{426}$ Ibid., 8.

${ }^{427}$ Peggy Heinkel-Wolfe, "Easy Credit Flourishes," Denton Record-Chronicle, March 16, 2013, http://www.dentonrc.com/local-news/local-news-headlines/20130316-easy-credit-flourishes.ece; Peggy HeinkelWolfe, "Customer Beware of Short Term Loans," Denton Record-Chronicle, March 17, 2013, http://www.dentonrc.com/local-news/local-news-headlines/20130317-customer-beware-of-short-term-loans.ece; Tabor and Gray, op. cit.

${ }^{428}$ City of Denton City Council Agendas, accessed November 21, 2016, http://www.cityofdenton.com/government/city-council/city-council-agendas-minutes-videos. ${ }^{429}$ Denton For Fair Lending's Facebook page, https://www.facebook.com/DentonForFairLending/. ${ }^{430}$ Walker Moore interview, p. 3.

${ }^{431}$ Jaime Adame, "Groups Oppose Payday Loans, Industry Growth in Texas," Abilene Reporter-News, January 8, 2011,

http://webcache.googleusercontent.com/search?q=cache:VrZ9UDHUWOwJ:www.reporternews.com/business/gro ups-oppose-payday-loans-industry-growth-in-texas-ep-388444568-

$350211611 . h t m l+\& c d=21 \& h l=e n \& c t=c \mid n k \& g l=u s$.

${ }_{432}$ Walker Moore Interview, p. 18.

${ }^{433} \mathrm{Jim}$ Mitchell Interview, pp. 6-7. See also: Rob Norcross, Consumer Service Alliance of Texas, Texas Senate, Business and Commerce Committee, Hearing on SB 251 and SB 253, February 22, 2011, http://www.senate.state.tx.us/75r/Senate/commit/c510/handouts11/0223-RobNorcross.pdf.

${ }^{434}$ Jim Mitchell Interview, pp. 6-7

${ }^{435}$ Acecashexpress.com, accessed November 21, 2016, https://www.acecashexpress.com/corporate/community.

${ }^{436}$ Rev. Gerald Britt Interview, p. 45.

${ }^{437}$ Josephine Lopez Paul Interview, p. 14.

438 Jerry Allen Interview, p. 13.

439 Jim Mitchell Interview, p. 19.

${ }^{440}$ The petition for review of the Denton Appeals court victory was denied by the Texas Supreme Court on June 17, 2016. ACE Cash Express Inc. v. Denton, case number 02-14-00146-CV, in the Second Court of Appeals of the State of Texas.

${ }^{441}$ For the purposes of this summary, we define "density-type" ordinances as those that regulate payday lender density (e.g., minimum distances between payday lenders and either each other or sensitive uses, per capital limits, and numerical limits) or ban payday lenders from a portion or all of a jurisdiction. Density-type ordinances contrast with stronger "business regulation" ordinances and weaker zoning ordinances that only require a special 
permitting process or only limit hours of operation/physical features of payday outlets (e.g., lighting, signage, security cameras).

${ }^{442} 2014$ School for Finance Justice held in Fresno by YLI, https://ylisanfrancisco.wordpress.com/2014/08/11/yliyouth-at-the-second-annual-school-for-financial-justice-in-fresno/.

${ }^{443}$ Ann Baddour, Jamie Tegeler-Sauer, and Deborah Fowler, Payday and Auto Title Lending in Texas: Market Overview and Trends 2012-2015, Texas Appleseed, Austin, Texas, June 1, 2016, https://www.texasappleseed.org/sites/default/files/Payday-Auto-Title-Lending-Tx_MktOv-Trends20122015Rev.pdf. According to this White Paper, thirty-five Texas cities with a total population of 9.3 million have adopted the "the unified ordinance." https://www.texasappleseed.org/sites/default/files/Payday-Auto-TitleLending-Tx MktOv-Trends2012-2015Rev.pdf.

${ }^{444}$ Rev. Gerald Britt Interview, p.50.

${ }^{445}$ https://sfbay.ca/2012/04/25/predatory-loan-shops-become-the-prey/.

446 Barry Shlachter, "Fort Worth Takes a New Look at Restrictions on Payday Lending, Star-Telegram, May $16,2014$. www.star-telegram.com/news/business/article3858026.html.

${ }^{447}$ Plaintiff's Original Petition and Application for Temporary and Permanent Injunction, District Court of Denton County Texas, July 19, 2013, http://www.tml.org/p/Ace\%20Cash\%20Express\%20v.\%20Denton\%20\%200riginal\%20Petition.pdf.

${ }^{448}$ Brian Gaar, "Citing City's New Rules, Payday Lender Closing Austin Locations," Austin-American Statesman, November 3, 2012, p. B5.

449 Jerry Allen Interview, p. 8.

450 Jerry Allen Interview, p. 18.

451 Susan Williams Interview, p. 50.

452 Patrick Danner, “Appeals Court Nixes Payday Lender Class-Action Suit," San Antonio Express-News, Updated: July 29, 2016, 5:27 pm, http://www.expressnews.com/business/local/article/Appeals-court-nixes-payday-lenderclass-action-8651614.php?t=1b99f67b0fb44b34a7\&cmpid=fb-premium.

${ }^{453}$ Sheila R. Foster, "Breaking Up Payday: Anti-Agglomeration Zoning and Consumer Welfare," Ohio State Law Journal, Vol. 75, no. 1, 2014, pp. 57-102.

${ }^{454}$ According to Professor Steven Graves of California State University-Northridge, the number of outlets per 100,000 inhabitants declined by 2.14 in California jurisdictions with ordinances compared to a decline of 1.28 in areas without ordinances. The same difference was evident within Silicon Valley. The number of outlets per 100,000 people declined by 1.29 in Silicon Valley jurisdictions with ordinances compared to a decline of 0.45 in jurisdictions without ordinances.

455 Lee Davidson, "Payday-Loan Reform Bill Still Rolling," Salt Lake Tribune, February 27, 2014, http://archive.sltrib.com/story.php?ref=/sltrib/politics/57607234-90/bill-borrowers-dunnigan-industry.html.csp; Lee Davidson, “New Payday Loan Regulations Receive Final OK," Salt Lake Tribune, March 9, 2016, http://www.sltrib.com/home/3640906-155/new-payday-loan-regulations-receive-final.

456 Assembly California Legislature Committee on Banking and Finance Agenda for January 11, 2016, http://abnk.assembly.ca.gov/sites/abnk.assembly.ca.gov/files/January\%2011,\%202016\%20Hearing\%20Info.pdf and "Compilation of Payday Loan Legal Settlements," California Reinvestment Coalition, accessed December 9 , 2016, https://calreinvest.wordpress.com/category/coalition-against-payday-predators/page/2/.

457 Ibid.

458 See Senate Bill 515 (2013), http://www.leginfo.ca.gov/pub/13-14/bill/sen/sb 0501-

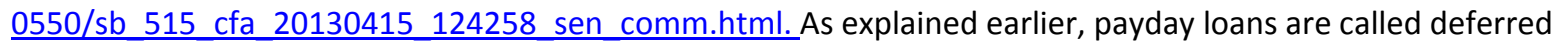
deposit transactions under California law.

${ }^{459}$ California Assembly Committee on Banking and Finance Hearing on Consumer Loans, May 7, 2013, http://www.leginfo.ca.gov/pub/13-14/bill/sen/sb_0301-0350/sb_318_cfa_20130621_120917_asm_comm.html; California Assembly Committee on Banking and Finance Hearing on Deferred Deposit Transactions, April 13, 2011, http://www.leginfo.ca.gov/pub/11-12/bill/asm/ab_1151-1200/ab 1158 cfa 20110422 102516 asm comm.html. 460 "Tell the CFPB: Payday Loans Must Include Consumer Protections," California Reinvestment Coalition, accessed December 9, 2016, http://org2.salsalabs.com/o/7297/p/dia/action3/common/public/?action KEY=18178. 
461 "SVCF Urges Strong Federal Payday Lending Rules at Town Hall," Silicon Valley Community Foundation, August 3, 2016, http://www.siliconvalleycf.org/blog/announcements/svcf-urges-strong-federal-payday-lending-rulestown-hall. $\overline{462}$ Letter from Silicon Valley Community Foundation to Richard Cordray, Director, Consumer Financial Protection Bureau, April 3, 2015, http://www.siliconvalleycf.org/community-foundation-coalition-letter.

${ }^{463}$ Commentary by Gerald Britt: "How Rep. Hensarling's Plan Will Strip Wall Street Oversight," Dallas Morning News, June 16, 2016, http://www.dallasnews.com/opinion/latest-columns/20160616-gerald-britt-how-rep.hensarlings-plan-will-strip-wall-street-oversight.ece; Larry James Urban Daily, Blog, May 27, 2016, http://larryjamesurbandaily.blogspot.com/2016/05/join-fight.html; “Mobilizing Dallas to Bring Significant Changes to Predatory Lending Practices," League of Women Voters of Dallas, accessed on December 20, 2016, http://lwvdallas.org/payday.html.

${ }^{464}$ Letter to Richard Cordray on Office of the City Council, City of Daly City Letterhead, July 7, 2015.

465 Jerry Allen, "Texas Needs a One-Two Punch Against Payday Lending," Dallas Morning News, December 16, 2015.

${ }^{466}$ Ramona Giwargis, "San Jose: Assembly Race Pits Madison Nguyen Against Ash Kalra," Mercury News, May 21, 2016, 5:07 am, http://www.mercurynews.com/bay-area-news/ci 29922435/san-jose-assembly-race-pits-madisonnguyen-against.

467 "California District 27 State Assembly Results: Ash Kalra Wins," New York Times, November 21, 2016, http://www.nytimes.com/elections/results/california-state-house-district-27.

468 Lee Davidson, "Trapped for Cash: Thriving in Utah," Deseret News, November 14, 2005, http://www.deseretnews.com/article/635161153/Thriving-in-Utah-Payday-loan-stores-are-popping-upeverywhere.html?pg=all.

469 Ibid.

470 Lee Davidson, "Utah Too Lax on Payday Lenders?" Deseret News, November 15, 2005, http://www.deseretnews.com/article/635159502/Utah-too-lax-on-payday-lenders.html?pg=all.

${ }^{471}$ Anti-Poverty Coalition of Great Dallas's Facebook page, accessed December 9, 2016, https://www.facebook.com/DallasFightsPoverty/; Serve Denton's Facebook page, accessed December 9, 2016, https://www.facebook.com/servedenton/.

472 Goodwin Simon Strategic Research, San José Payday Loan Store Restrictions Survey, op. cit.

473 "Payday Lenders Less Popular than Liquor Stores, Majority of Voters Would Support Moratorium, according to San Jose poll," Center for Responsible Lending, February 23, 2011,

http://www.responsiblelending.org/media/payday-lenders-less-popular-liquor-stores-majority-voters-wouldsupport-moratorium-according.

${ }^{474}$ Christa Bigue, "Youth Take a Stand on Payday Lending's Crippling Affect on Daly City," Pacifica Patch, September 9, 2013, http://patch.com/california/pacifica/youth-take-a-stand-on-payday-lendings-crippling-affecton-daly-city and ibid. p. 2.

475 "Coalition Launches Bus Ad Campaign to Discourage Payday Loan Usage among San Jose R esidents," California Reinvestment Coalition, June 20, 2012, http://www.calreinvest.org/news/coalition-launchesbus-ad-campaign-to-discourage-payday-loan-usage-among-san-jose-residents.

476 “One: Innovation Through Philanthropy," Silicon Valley Community Foundation, accessed November 21, 2016, http://www.siliconvalleycf.org/one-innovation-through-philanthropy/spring-11/one-innovation-throughphilanthropy-spring-11.pdf, p. 11.

${ }^{477}$ Keith Ogden Interview, pp. 17-18.

${ }^{478}$ Pacifica Resource Center, accessed December 8, 2016, available at https://web.archive.org/web/20160317131437/http://pacresourcecenter.org/blog/?page id=1125

479 James Zahradka interview, pp. 21-22.

480 Rev. Gerald Britt Interview, p. 54.

${ }^{481}$ Sendhil Mullainathan and Eldar Shafir, Scarcity: The New Science of Having Less and How It Defines Our Lives (New York, NY: Henry Holt \& Company, 2013).

${ }^{482}$ George Kinder, Seven Stages of Money Maturity (New York: Dell, 2001), 161. 
${ }^{483}$ Art Sutherland Interview, p. 1.

${ }^{484}$ Laura Polacheck, “Money Magazine Names AARP Utah Area Coordinator Art Sutherland as Utah's Money Hero," Aarp.org, July 9, 2014, http://states.aarp.org/money-magazine-names-aarp-utah-area-coordinator-art-sutherlandas-utahs-money-hero-sc-ut-wp-money/.

${ }^{485}$ Youth Leadership Institute, YLI.org, accessed December 8, 2016, http://yli.org/wpcontent/uploads/2015/11/YLI-Profile-FY-15-16.pdf.

${ }^{486}$ Danielle Ayers Interview, p. 22.

487 Ibid., 8.

488 Ibid., 22.

${ }^{489}$ Stephanie Mace Interview, p. 4.

490 Ibid., 4.

${ }^{491}$ Kyra Kazantzis Interview, p. 44.

492 Josephine Lopez Paul Interview, pp. 28-31.

${ }^{493}$ Danielle Ayers Interview, p. 22.

${ }^{494}$ Walker Moore Interview, p.7.

495 Ibid., 8.

${ }^{496}$ Arlington City Council Meeting Minutes, November 10, 2015, http://arlingtontx.granicus.com/MinutesViewer.php?view id=9\&clip id=1918.

${ }^{497}$ Walker Moore interview, p. 7.

${ }^{498}$ Chris Peterson Interview, p.15.

${ }^{499}$ Paul Kiel, "Whack-a-Mole: How Payday Lenders Bounce Back When States Crack Down," Propublica.org, August 6, 2013, 8:00 a.m., https://www.propublica.org/article/how-payday-lenders-bounce-back-when-states-crack-down 
Exhibit A: Study Interviewees*

\section{Utah Interviewees}

Nicole Cottle, Assistant Manager, West Valley City

Lee Davidson, Reporter, The Salt Lake Tribune

Phillip Hill, Community Development Director, Midvale City Council

Linda Hilton, formerly of Crossroads Urban Center

Christopher Peterson, University of Utah School of Law (by phone)

Margaret Peterson, former member of the West Valley City Council

Art Sutherland, Coalition of Religious Communities

\section{California Interviewees}

Eleanor Clement Glass, Silicon Valley Community Foundation (by phone)

Mike Guingona, Daly City Council (by phone)

Kyra Kazantzis, Law Foundation of Silicon Valley

Paul Leonard, formerly of the Center for Responsible Lending

Tim Lohrenz, formerly of the Insight Center for Community Economic Development

Christian Luna, Sacred Heart Community Service (by phone)

Liana Molina, California Reinvestment Coalition

Rafael Morales, formerly of Silicon Valley Community Foundation

Keith Ogden, Community Legal Services of East Palo Alto

Fahad Qurashi, Youth Leadership Institute

Erica Wood, Silicon Valley Community Foundation

James Zahradka, Law Foundation of Silicon Valley

\section{Texas Interviewees}

Jerry Allen, former member of the Dallas City Council

Danielle Ayers, Friendship-West Baptist Church

Anne Baddour, Texas Appleseed (by phone)

Gerald Britt, CitySquare

Marc Jacobson, Jewish Community Relations Council of the Jewish Federation of Greater Dallas Josephine Lopez Paul, Dallas Area Interfaith, of the Industrial Areas Foundation

Stephanie Mace, United Way of Metropolitan Dallas

Jim Mitchell, Reporter, the Dallas Morning News

Walker Moore, Dallas Area Interfaith, of the Industrial Areas Foundation

Katie Murray, Wilshire Baptist Church

Pat Smith, Serve Denton

Kayce Strader, formerly of Serve Denton

Susan Williams, AARP Texas

*All interviews were conducted in person unless otherwise indicated. 


\section{Exhibit B}

\section{Anti-Poverty Coalition of Greater Dallas: Meeting Minutes}

Minutes from Meeting Held on Thursday, January 6, 2011 at 1:30pm

In Attendance:

1. Gerald Britt: CitySquare (formerly Central Dallas Ministries)

2. Jessica Davila: CitySquare (formerly Central Dallas Ministries)

3. Rachel Lamb: CitySquare (formerly Central Dallas Ministries)

4. Dr. Tim Bray: University of Texas at Dallas

5. Stephanie Werner: United Way of Metropolitan Dallas

6. Marlene Cohen: National Council of Jewish Women

7. Bob Cook: HUD

8. Jacqueline West (On behalf of Martha Blaine), Community Council of Greater Dallas

9. Susan Williams: AARP

10. Erma Saracho: City of Dallas Office of Economic Development

11. Marc Jacobson: Jewish Community Relations Council

12. Marlene Gorin: Jewish Community Relations Council

13. Kay Barger: Prestige Community Credit Union

14. Christie Myers: Dallas Regional Chamber

15. Lynn Rossol: Catholic Diocese of Dallas

16. Jim Reid: Momentum Texas (Bank on Dallas)

17. Catarina Torres (Representative for Sister Mary Anne Owens): Catholic Charities

18. Monica Egert-Smith: Communities Foundation of Texas

19. Victor Garza: Consumer Credit Counseling Service of Greater Dallas

20. Gerald Davis: Baptist General Convention of Texas

\section{Agenda}

1. Welcome and Introductions Rev. Gerald Britt, CitySquare

\section{Sub-Committee Reports}

- Financial Literacy - Christie Myers, Dallas Regional Chamber

$\checkmark$ Target group: families

$\checkmark$ Next phase: looking into other organizations like Headstart and reviewing their research.

$\checkmark$ Idea of polling people in community to find out what they know and don't know. 
$\checkmark$ Possible town hall meetings

$\checkmark$ Getting this in school curriculum - reviewing groups already doing this.

$\checkmark$ Will choose a small area of Dallas as an initial focus area.

2

- Educating and Lobbying Elected Officials - Rev. Gerald Britt, CitySquare

$\checkmark$ December 13, 2010: AARP, UWMD, CitySquare appeared to the City of Dallas Quality of Life Committee to draft and adopt a resolution to go to state legislature to close the CSO loophole

$\checkmark$ All partners in this coalition need to meet with City Council Member Jerry Allen. He is very passionate in advocating this cause.

$\checkmark$ F.I.C.A. South Dallas Church community plans to also meet with city council - they will need critical mass of people.

$\checkmark$ Planning a "Day at the Capitol”.

$\checkmark$ One pager: We need organizations to give permission to list their organization name on a one-page fact sheet to show support. This one-pager will be given to legislators, and possibly the media. The one-pager will be circulated via e-mail.

- Key officials in Dallas region:

- Rep. Vickie Truitt, Chair, House Committee on Pensions, Investments and Financial Services

- Vice-Chair, Rep. Rafael Anchia, Vice-Chair, House Committee on Pensions, Investments and Financial Services

- Rep. Burt Solomons

- Sen. John Carona, Chair, Senate Committee on Business and Commerce

$\checkmark$ As people are setting up meetings, please let Stephanie Werner know and please also share information on the meeting outcomes. Keep meeting with legislators even if others have already done so.

- Creating Public Awareness - Ralph Adams, Urban League

Ralph Adams could not be present; but here are the goals that the sub-committee set at the last Coalition meeting:

1. Collaborative communication outreach among agencies.

2. Public awareness of alternative resources to payday loans.

3. Educate coalition organizations' employees and volunteers about predatory lending. We can fight money with heart and word of mouth. 
There was discussion about these points, including the following questions and feedback:

$\checkmark$ Is there a PowerPoint available to the public that we can use to train our staff?

$\checkmark$ Nothing specific but coalition members will share anything that they are already using with other members of the coalition.

3

$\checkmark$ We need to build an infrastructure for all organizations to share contacts, handouts, etc.

Victor Garza will look into creating a YahooGroups site that will allow us to share documents more easily.

$\checkmark$ We're hitting this in tax season. People are already getting refund anticipation loans. We need to create more public awareness of VITA sites.

\section{Coalition Action Planning Facilitated By Dr. Tim Bray}

A lot of this is a great opportunity for us to not re-invent the wheel. Dr. Bray reviewed a work plan template that was developed by the Vera Institute.

Dr. Bray discussed the importance of the Coalition clarifying communications processes, including: What's the policy or procedure for developing and approving a public document? Who can speak for the Coalition and what approval do they need?

Dr. Bray encouraged all sub-committees to use the work plan template to turn their objectives into attainable action plans, with a particular focus on who will do what by when.

Time Sensitive Items:

$\checkmark$ Connecting others interested in this and similar issues who are not at the table today. This includes other coalitions in the Dallas area.

$\checkmark$ Need to clearly define the Coalition's mission statement in a way that shows that the Coalition is not a single-issue group.

Potential Barriers:

$\checkmark$ Concerned about what is deliverable and can bring some relief. Town hall at churches and parishioners want to know what the alternative is to payday lending. We need to identify lending institutions we feel comfortable in referring as well as financial literacy courses available in the community. In short, what is going to take payday lending's place?

$\checkmark$ Are there non-CSO lenders who provide short term solutions? Can we identify them? This could be a legitimate step in the right direction.

$\checkmark$ Can we as a coalition put out a 1 pager of alternatives?

$\checkmark$ We have a simple grid of "Where do you start when you need money?"

$\checkmark$ We might not refer people to a particular credit union, but to the credit union association.

$\checkmark$ The challenge of engaging people on the issue of payday lending:

$\checkmark$ “Why should I care?” How do we get people engaged in this issue even if they don't feel this issue affects them?

$\checkmark$ Complexity of the issue makes people lose interest: people have no understanding of interest or APR, how do we tell it in a simple and engaging way? 
$\checkmark$ What is the capacity and quality of various financial literacy education programs?

4

Potential Resources

$\checkmark$ Where can we get data on CSO locations geo-mapped on city areas?

$\checkmark$ A stronger social justice message being shared with our congregations and all places of worship. This would make the field more fertile.

$\checkmark$ It helps that the subject of payday lending has become something nationally known and generally more recognizable than it was a year ago.

$\checkmark$ What role, if any, will the development of the new federal Consumer Protection Bureau have in the effort to regulate payday lenders?

4. Review and Next Steps Rev. Gerald Britt, CitySquare

$\checkmark$ General Coalition e-mail list is maintained by Marc Jacobson. Contact him if you would like to be on that list and are not already on it.

$\checkmark$ YahooGroup will be developed by Victor Garza.

$\checkmark$ Stephanie Werner will finalize the Payday Lending one-pager and email it by January 10th; organizations need to provide Stephanie permission to include their organizational names by Jan 14.

$\checkmark$ Sub-Committees need to meet and create a "Work Plan" on how they will reach their objectives.

$\checkmark$ It was agreed that the Coalition will meet every 6 weeks, on Thursdays from 2pm-4pm.

- Next Meeting: Thursday, February 17, 2-4pm, United Way

$\checkmark$ Let us know if your organization is interested in hosting a meeting in the future. After the February 17th meeting, we will likely have rotating meeting sites.

\section{Adjourn}

Next Meeting: February 17, 2011 2:00-4:00pm

United Way of Metropolitan Dallas

1800 N. Lamar, Dallas 75202

For more information and to RSVP, contact Marc Jacobson at MJacobson@jfgd.org

\section{Anti-Poverty Coalition of Greater Dallas : Meeting Minutes}


Thursday, February 17, 2011 at 2:00pm

In attendance

1. Gerald Britt, CitySquare

2. Jessica Davila, CitySquare

3. Rachel Lamb, CitySquare

4. Denise Gomez, CitySquare

5. Lynn Rossol, Catholic Diocese of Dallas

6. Katie Dickinson, Senior Source

7. Ralph Adams, Urban League

8. Marlene Cohen, National Council of Jewish Women

9. Stephanie Werner, UWMD

10. Marc Jacobson, Jewish Community Relations Council

11. Jim Reid, Momentum

12. Bob Cook, HUD

13. Jenny Stewart, CCCS

14. Dr. Darlene Williams. HUD

15. Kay Barger, Prestige Community Credit Union

16. Christie Myers, Dallas Regional Chamber

\section{Agenda}

1. Welcome and Introductions Stephanie Werner, UWMD

\section{Sub-Committee Reports}

- Educating and Lobbying Elected Officials - Rev. Gerald Britt, CitySquare

$\checkmark$ Rev. Britt reported that a resolution calling for regulating payday lenders passed in the Dallas City Council - although it was fairly weak in its wording.

$\checkmark$ There is momentum at the Texas legislature for closing the loophole, but continued advocacy is needed.

$\checkmark$ A one-page handout was distributed with calling information for the Senate Business and Commerce Committee.

$\checkmark$ The Senate Business and Commerce Committee will be holding a hearing on Tuesday, February 22, 2011.

- Financial Literacy -- Christie Myers, Dallas Regional Chamber

$\checkmark$ Kay Barger presented the Financial Literacy sub-committee report.

$\checkmark$ The sub-committee has established a Yahoogroup for communicating.

$\checkmark$ Plan to utilize surveys from UWMD VITA sites to establish needs and wants of community. 
$\checkmark$ Plan to gather a list of resources and services providing financial literacy education. Possibly review the curriculum and requirements to attend.

- Creating Public Awareness - Ralph Adams, Urban League

$\checkmark$ Planning a campaign soon to get information out to the community.

$\checkmark$ Jim Reid added that the Bank on Dallas program is interested in working with the Anti-

Poverty Coalition on this effort because it is limited in its public .awareness budget and he sees outreach through community organizations as the best approach.

$\checkmark$ There are several alternatives being looked at to payday lenders:

o Progresso Financio, a California company making small dollar loans at 36\% APR

o FDIC had model program in 2008 with 31 financial institutions on how to carry out successful small dollar loan programs

o "Bank on San Francisco" established a fair small dollar loan program.

\section{Discussion on Ways to Enhance Coalition Efforts Marc Jacobson, JCRC}

\section{Overview:}

$\checkmark$ We are tweaking the way the Coalition is lead. The coalition was originally started by JCRC, UWMD, and CitySquare, which continued leading through an interim steering committee. The steering committee will now be expanded to include the sub-committee chairs.

$\checkmark$ The steering committee has met to address issues of coalition communication and cohesiveness.

$\checkmark$ Victor Garza set up a Yahoo Groups account for the Coalition as a whole. This tool is particularly for coalition-wide access to documents. A one-page handout with instructions for joining was distributed.

$\checkmark$ If a sub-committee has a document they want to put out under the Coalition's name, they should send it to Marc Jacobson to be distributed to the Coalition listserv in advance of the next meeting, at which the content will be discussed and voted on.

$\checkmark$ Messaging: We want to make sure every organization is in accord in their message of what the Coalition does and who we are as an organization. On the flip-side of the payday lending one-page fact sheet is a paragraph-long description of the Anti-Poverty Coalition that should be used as a model of how to describe the coalition.

\section{Discussion:}

$\checkmark$ There was some discussion about the need to keep in mind other issues for reducing poverty, including job creation and developing job skills, with the understanding that the payday lending and financial literacy focus is just the initial agenda item of the Coalition.

$\checkmark$ There was discussion about the need to invite other groups to the table to continue to expand participation in the coalition, including reaching back out to those groups have participated previously.

$\checkmark$ Christie Myers discussed the questions the Financial Literacy sub-committee is struggling with in terms of focus -- knowing what resources are available and how the Coalition can best make a positive impact.

$\checkmark$ Dr. Williams with HUD described their successful partnership with the Federal Reserve and FDIC to establish a financial literacy curriculum at Paul Quinn College. She emphasized the need to actually get the curriculum's utilized by the community. 
$\checkmark$ Rev. Britt suggested the financial literacy sub-committee could look at what a model financial literacy program would look like, consist of, and then find out who's doing that sort of program. Then you figure out how to open the door the get more people in poverty to the really good financial literacy programs.

$\checkmark$ Marc Jacobson suggested that the Anti-Poverty Coalition can most have an impact by utilizing the fact that we are an umbrella organization and can bring lots of people, organizations and resources together.

$\checkmark$ There was some discussion about the need to ensure that we pay attention to the need to measure the impact of our efforts towards reducing poverty, and Stephanie Werner mentioned that UWMD is currently contracting with UTD to do an general data collection effort to see what progress is being made to move people out of poverty in the Dallas area.

4. Review and Next Steps Stephanie Werner, UWMD

We've had a good discussion and we look forward to seeing you at the next meeting to continue this conversation. The next meeting will be on Thursday, March 31, 2011 from 2pm$4 \mathrm{pm}$ at the Urban League of Greater Dallas.

\section{Adjourn}




\section{Exhibit C}

\section{“Fair Lending Campaign" Binder}

\section{Table of Contents}

- Alternatives Do Exist

o Options

o Small-dollar loans in Dallas

- Density Maps

o District

o City

- Letters of Support

o Rep Eric Johnson and Senator Royce West

o AARP

o CitySquare

o First Unitarian Church of Dallas

o Friendship West Baptist Church

o Jewish Community Relations Council of Greater Dallas

o Jewish Family Services

o National Council of Jewish Women

o Temple Emanu-El

o United Way of Metropolitan Dallas

o Wilshire Baptist Church

- Media

o http://www.dallasnews.com/opinion/editorials/20110428-editorial-local-andstate-officials-must-act-now-to-fix-payday-lending.ece

o http://www.mysanantonio.com/default/article/Cinderella-ending-but-nosolution-1388986.php

0 http://www.dallasnews.com/opinion/editorials/20110204-editorial-it-is-time-toclose-the-payday-lending-loophole.ece

o http://www.texasobserver.org/cover-story/taking-an-interest

- Resources

o Closing the CSO Loophole 
Exhibit D

\section{Anti-Poverty Coalition of Greater Dallas}

June 23, 2011

The Honorable Mayor Caraway and Dallas City Council

Dallas City Hall

1500 Marilla St.

Dallas, Texas 75201

Dear Mayor Caraway and City Council Members,

The Anti-Poverty Coalition of Greater Dallas applauds the Dallas City Council's passage of a land-use zoning ordinance on May 25, 2011 that will reduce the proliferation of payday and auto title lenders in our City.

Today, we applaud you again for proposing a realistic and substantive policy change, and hope it will once again result in a unanimous passage of this ordinance. We understand that some families need short-term loans during an emergency and believe this ordinance is a fair compromise that would not prohibit access to these services.

The proposed ordinance places reasonable limitations on the number of installment payment, the number of renewals, and on the amount borrowed; and is consistent with the information and standards reported by the industry. The industry states that more than 90 percent of their customers who are facing financial difficulties use their short-term products wisely. Furthermore, they already work with customers that need extra time by arranging up to four extensions and, to a small percentage, they offer an extended payment plan at no additional charge.

We appreciate you listening to our concerns and thank you in advance for supporting this ordinance. We look forward to continuing to collaborate together to reduce poverty in the Dallas area.

Sincerely, The Anti-Poverty Coalition of Greater Dallas 


\section{Acknowledgements}

The authors wish to thank Silicon Valley Community Foundation (SVCF) for underwriting this report. We are grateful for SVCF's Rafael Morales and Sarah Davison, our project officers, and also appreciate the excellent work of Michael Heffer of Consumer Action, who acted as our project's fiscal sponsor.

To the extent that our report comes alive, it is because of the generous cooperation and insights we received from our thirty-two interviewees in California, Texas, and Utah. Their efforts to find local solutions to the problems associated with payday lending inspired us and made it an honor to tell their story. Jean Ann Fox, the grande dame of anti-payday activism, was not one of our official interviewees, but she helped us identify our interviewees.

The editing and production of the final report benefited from the work of Cheryl Burbank, Ben Jacobs, Austin Megli, Logan Milgore, and Jaclyn Page of the University of New Mexico Law School.

Finally, most academics are workaholics and we are no exceptions. We thank our spouses, Carol Blackwell and Stewart Paley, for supporting our time allocation choices. 


\section{About the Authors}

\section{Robert N. Mayer}

Robert N. Mayer is a professor in the Department of Family and Consumer Studies at the University of Utah. He earned his PhD in sociology from the University of California at Berkeley. Dr. Mayer's research has exposed consumer problems, evaluated consumer policy interventions, and examined the U.S. and global consumer movements. In 2013, Dr. Mayer published (with Larry Kirsch) Financial Justice: The People's Campaign to End Lender Abuse (Praeger, 2013) - an analysis of how the landmark Consumer Financial Protection Bureau was established in the U.S. In 2015, he co-edited (with Stephen Brobeck) Watchdogs and Whistleblowers, a research guide to consumer activism worldwide. Dr. Mayer has been a board member of several consumer organizations, including the Consumer Federation of America and National Consumers League, and he was the representative to Consumers International of the American Council on Consumer Interests. Additional information about Dr. Mayer's professional activities is found at: http://fcs.utah.edu/profile.php?unid=u0028169.

\section{Nathalie Martin}

Nathalie Martin is the Frederick M. Hart Chair in Consumer and Clinical Law at University of New Mexico School of Law ("UNMSOL"), where she regularly teaches commercial and consumer law. She has written a number of books and articles about bankruptcy, payday and title loans, foreclosure, and many other topics, which are listed at http://lawschool.unm.edu/faculty/martin/publications.php. Previously she completed several empirical studies of payday lending, attitudes toward credit and interest rates, and debt collection, as well as a qualitative empirical study of the credit use habits of undocumented persons. She is a regular contributor to credit slips, found at http://www.creditslips.org/creditslips/\#tp, one of the nation's leading blogs on debtor-creditor issues. Prior to teaching, she practiced law in Philadelphia and Boston. Professor Martin was the American Bankruptcy Institute Scholar in residence for the Fall of 2005. Professor Martin is also an American Bar Association Fellow, a member of the American Law Institute and the American College of Bankruptcy. The endowed chair that she occupies, the Frederick M. Hart Chair in Consumer and Clinical Law, is thought to be one of the only chairs in the country dedicated to scholarly pursuits in the consumer law area. 